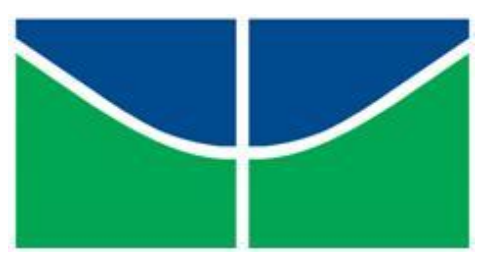

UNIVERSIDADE DE BRASÍLIA

INSTITUTO DE PSICOLOGIA

Departamento de Processos Psicológicos Básicos

Programa de Pós-GraduAÇÃo EM CIÊnCIAS do COMPORTAMENTO

\title{
O PADRÃO DE TRAJETÓRIA VISUAL PARA O RECONHECIMENTO DE EXPRESSÕES FACIAIS
}

HÉLIDA ARRAIS COSTA VIEIRA

Brasília

2015 
UNIVERSIDADE DE BRASÍLIA

INSTITUTO DE PSICOLOGIA

Departamento de Processos Psicológicos Básicos

Programa de Pós-GraduaçÃo em CiênCIAS do Comportamento

\title{
O PADRÃO DE TRAJETÓRIA VISUAL PARA O RECONHECIMENTO DE EXPRESSÕES FACIAIS
}

\author{
HÉLIDA ARRAIS COSTA VIEIRA \\ Orientadora: WÂNIA CRISTINA DE SOUZA, Ph.D. \\ Tese apresentada ao Programa de Pós- \\ Graduação em Ciências do Comportamento, do \\ Departamento de Processos Psicológicos \\ Básicos, do Instituto de Psicologia, da \\ Universidade de Brasília, como requisito para a \\ obtenção do título de Doutor em Ciências do \\ Comportamento - Área de Concentração: \\ Cognição e Neurociências do Comportamento.
}

Brasília, Agosto de 2015 


\author{
UNIVERSIDADE DE BRASÍLIA \\ INSTITUTO DE PSICOLOGIA \\ Departamento de Processos Psicológicos Básicos \\ Programa de Pós-Graduação em Ciências do Comportamento
}

Banca Examinadora

Presidente: Profa. Dra. Wânia Cristina de Souza

Departamento de Processos Psicológicos Básicos

Universidade de Brasília

Membro externo: Profa. Dra. Elisângela Nogueira Teixeira

Departamento de Letras Vernáculas

Universidade Federal do Ceará

Membro externo: Prof. Dr. Leonardo Gomes Bernardino

Instituto de Psicologia

Universidade Federal de Uberlândia

Membro interno: Profa. Dra. Maria Ângela Guimarães Feitosa

Departamento de Processos Psicológicos Básicos

Universidade de Brasília

Membro interno: Prof. Dr. Luciano Grüdtner Buratto

Departamento de Processos Psicológicos Básicos

Universidade de Brasília

Membro suplente: Profa. Dra. Valéria Reis do Canto Pereira

Curso de Fonoaudiologia - Faculdade de Ceilândia

Universidade de Brasília 


\section{Epígrafe}

"Don't you think you're gonna make a discovery every week or even every year.

You have to examine your own personality: are you capable of being really patient? I've never been bored. Hardly ever. Can you take a lot of readings? And record things? Or spend a lot of time, maybe alone, for reward may come months later, you know? If that doesn't appeal to you, keep out of science. It's glamourous... You hear about the glamour and you don't hear about the frustations or experiments that go wrong. And you have to change your hypothesis, start all over. And the findings you don't get... And the articles that don't get published.

If you can tolerate frustration, not get bored easily and you're really excited about what you're doing, then you're in the right field."

Dra. Brenda Milner Neurocientista Pioneira 


\section{Dedicatória}

Dedico esta tese a minha querida Vovó Mocita, que tanto torceu, tanto vibrou e tanto desejou, junto comigo, a finalização deste ciclo. Infelizmente, você não está mais entre nós, para presenciar esta conquista, querida Vovó. Não existem palavras suficientes para demonstrar a minha gratidão e traduzir a inspiração que você foi e que continua sendo para mim. Obrigada por ter me ensinado a ler, a estudar, a questionar, a buscar conhecimentos, a aprender, desde pequenina. Obrigada por ter sempre confiado na minha inteligência, pelas palavras de ânimo, pela admiração e pelo exemplo que sempre foi para mim. Nosso ideal se concretiza com este ciclo que se encerra. Esta tese é para você. 


\section{Agradecimentos}

Agradeço, primeiramente, aos meus pais, pelo amor maior, pelo apoio incondicional, pelo suporte emocional e financeiro, pelo investimento e pela disposição. Se hoje estou aqui, devo tudo a vocês. Mãe, obrigada pelas noites em claro, acompanhando os meus esforços, mesmo que a distância, por não permitir que eu desistisse, por sempre acreditar. Pai, obrigada por todo esforço e dedicação, por aceitar dividir comigo os desafios de programação, de cálculos e os percalços do caminho, que não foram poucos. Vocês são minhas inspirações.

Aos meus irmãos, por acreditarem em mim e me auxiliarem nos momentos de desânimo.

Ao meu marido, por ter caminhado comigo durante todo este período de doutorado, acreditando, apoiando e dividindo as dificuldades. Todo o meu amor e gratidão.

À minha orientadora, Profa. Wânia Cristina, por ter me acompanhado, visto o meu crescimento e por ter acreditado e investido em mim. Encerramos um ciclo de 7 anos, de mestrado e doutorado, em uma parceria que deu certo.

Aos professores Maria Angela Feitosa e Timothy Mullholand, pelos

ensinamentos, pelo conhecimento compartilhado. À Profa. Elisângela Teixeira, por ter me auxiliado e orientado, durante a execução dos experimentos e análise dos dados, contribuindo com seu enorme conhecimento e sua disponibilidade e generosidade.

Aos meus amigos e familiares, que em muitos momentos, privaram-se de minha companhia, compreendendo a minha ausência. E em tantos outros foram ouvidos, ombros, mãos amigas nesta caminhada, auxiliando-me a concretizar este ideal, finalizar este ciclo em minha vida.

Aos participantes, que despenderam seu tempo e esforço, voluntariamente, colaborando com uma das etapas desta tese.

À CAPES, pela bolsa de estudo, que permitiu a execução desta tese. 


\section{Resumo}

O reconhecimento de expressão facial é um tema estudado há anos como parte do processo de reconhecimento emocional universal. Seis emoções básicas (alegria, tristeza, surpresa, medo, raiva e nojo) são consideradas universais e reconhecidas em diferentes culturas. O presente trabalho buscou investigar o padrão de trajetória visual utilizado para o reconhecimento dessas expressões faciais, a influência do tipo de tarefa proposta e, consequentemente, do processamento cognitivo associado, buscando fornecer subsídios psicofísicos para a teoria da universalidade do reconhecimento de emoções. Para tanto, foram avaliados 56 indivíduos jovens, sem patologias neurológicas ou psiquiátricas associadas, com o auxílio de um equipamento de rastreamento ocular. Os participantes foram submetidos a duas tarefas envolvendo o reconhecimento de expressões faciais (nomeação e julgamento), que envolvem processamentos cognitivos top-down e bottom up, buscando investigar a influência da interação destas na trajetória visual. Os resultados apontam para uma especificidade da trajetória influenciada pelo tipo de atividade de reconhecimento emocional, com fixações iniciais concentradas no nariz e na boca, mas não pelo tipo de emoção, que interfere somente nos acertos e na quantidade de fixações.

Palavras-chave: Expressões Faciais, Emoções Básicas Universais, Trajetória visual, Rastreamento Ocular. 


\begin{abstract}
Facial expression recognition is a theme studied over the years as part of the universal emotion recognition process. Six basic emotions (happiness, sadness, surprise, fear, anger and disgust) are considered universal and recognized in different cultures. This study aimed to investigate the pattern of visual scanpath used for the recognition of these facial expressions, the influence of proposed task type and the associated cognitive processing, seeking to provide psychophysical subsidies to the theory of universal emotion recognition. Therefore, the eye movements of 56 young individuals without neurological or psychiatric disorders associated were registered by eyetracker equipment for eye tracking. Participants underwent two tasks involving the recognition of facial expressions (naming and judging), involving cognitive processing top-down and bottom up in order to investigate the influence of the interaction of the different visual scanpath produced by each individual. The results point to a specific scanpath directed by the type of emotional recognition activity, with initial fixations concentrated in the nose and mouth areas, but without the interference of the kind of emotion, which intervene only in hits and amount of fixations.
\end{abstract}

Key words: Facial Expressions, Basic Universal Emotions, Visual Scanpath, Eye Tracking. 


\section{Lista de Siglas e Abreviaturas}

3D: 3 dimensões

A: Alegria

AOI(s): Área(s) de Interesse

B: Boca

CAEE: Certificado de Apresentação para Apreciação Ética

CONEP: Comitê Nacional de Ética em Pesquisa

Dp: Desvio padrão

ES: entre sobrancelhas

FACS: Facial Action Coding System

m: Média

$M:$ medo

$\mathrm{N}$ : nariz

Ne: Neutro

NimStim: NimStim Set of Facial Expressions

No: Nojo

OD: Olho direito

OE: Olho Esquerdo

PCA:Principal component analysis (análise de componentes principais)

R: Raiva

S: Surpresa

Sobran D: Sobrancelha Direita 
Sobran E: Sobrancelha Esquerda

T: Tristeza

Te: Testa

T1: Tarefa 1

T2: Tarefa 2

TCLE: Termo de Consentimento Livre e Esclarecido

TDAH: Transtorno do Déficit de Atenção e Hiperatividade

VD: Variável Dependente

VI: Variável Independente 


\section{Lista de Figuras e Tabelas}

Figura 1. Distribuição percentual da escolaridade da amostra 61

Figura 2. Exemplificação da marcação de AOls nas fotografias de expressões faciais 62

Figura 3. Exemplo de setting experimental básico 64

Figura 4. Exemplificação do design da Tarefa 1 66

Figura 5. Exemplificação do design da Tarefa 2 .66

Figura 6. Linha do tempo das etapas componentes do experimento .67

Figura 7. Gráfico das médias estimadas, conforme as diferentes emoções e as tarefas propostas .74

Figura 8. Teste de Hipóteses para a verificação do efeito das emoções e da distribuição normal dos experimentos 79

Figura 9. Teste de hipóteses para as trajetórias conforme os experimentos .79

Figura 10. Porcentagem de hits nas AOls conforme sequência de fixações para as tarefas 1 (fig. A) e 2 (fig. B) - ALEGRIA .80

Tabela 1. Áreas cerebrais associadas às seis emoções básicas 29

Tabela 2. Variáveis dependentes e independentes do estudo 59

Tabela 3. Comparação do tempo de visualização dos estímulos entre os pares de emoções nas Tarefas 1 e 2 .72

Tabela 4. Diferença entre as médias de acertos por Tarefas e Emoções .73 
Tabela 5. Índice de significância da comparação entre as médias (ANOVA) dos acertos entre os pares de emoção .75

Tabela 6. Frequência dos pares de trocas entre as emoções (erros) para a Tarefa 1 .76

Tabela 7. Análise Fatorial para influência das VIs na quantidade de fixações .77

Tabela 8. Comparação entre as médias das fixações nos experimento e emoções .78

Tabela 9. Índices médios da distância de Levenshtein para as trajetórias ......8 


\section{Sumário}

Epígrafe ii

Dedicatória. iii

Agradecimentos iv

Resumo v

Abstract $\mathrm{vi}$

Lista de Siglas e Abreviaturas vii

Lista de Figuras e Tabelas............................................................... ix

Sumário 11

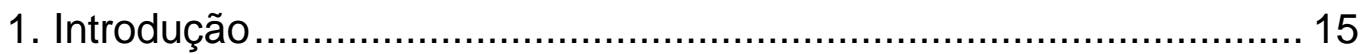

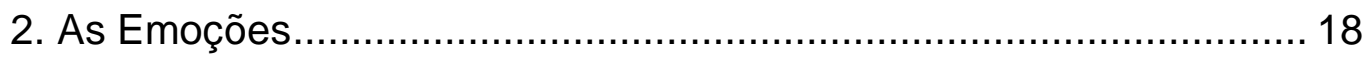

2.1 Definições de Emoção............................................................ 18

2.2 Tipos de Sinais Não Verbais de Emoção ...................................... 21

2.3 Categorização de Emoções....................................................... 23

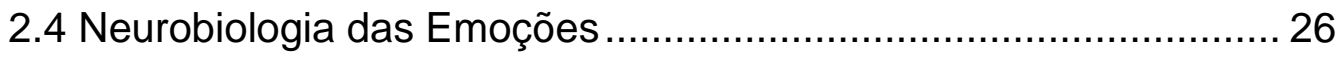

3. Reconhecimento de Expressões Faciais ........................................ 30

3.1 Teoria da Universalidade das Expressões Faciais ....................... 32

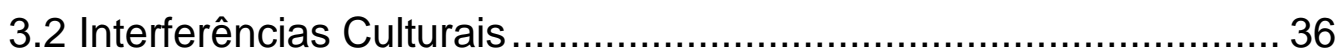

3.3 Expressões Faciais Emocionais Básicas..................................... 40

3.4 Processamentos Top-down e Bottom-up no Reconhecimento de Expressões Faciais 43 


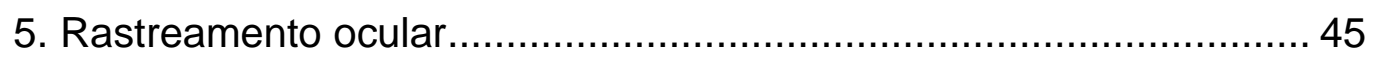

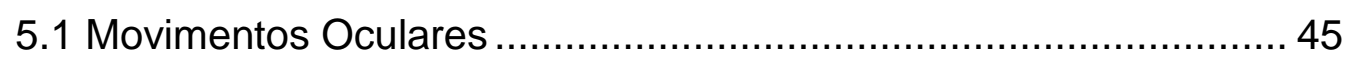

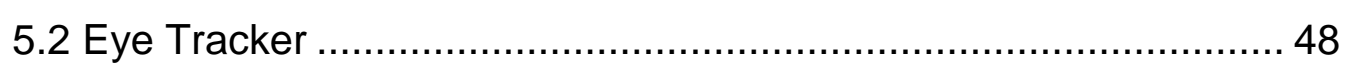

5.3 Rastreamento do Olhar e Reconhecimento de Expressões Faciais

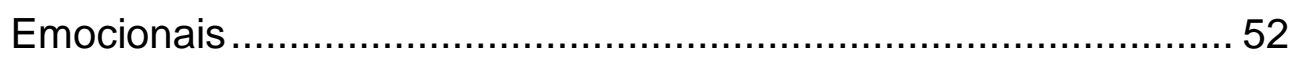

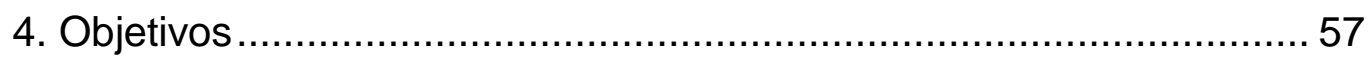

5. Delineamento Experimental e Hipóteses .......................................... 58

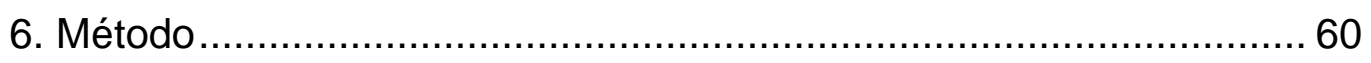

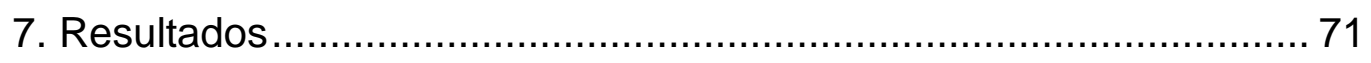

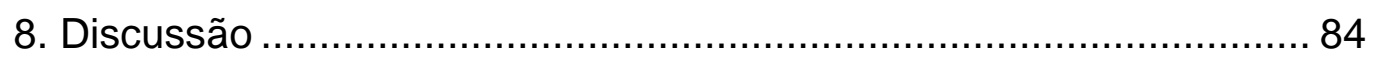

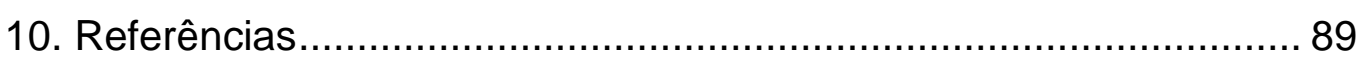

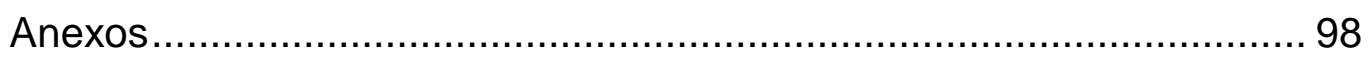

Anexo 1 - Questionário / Roteiro de Entrevista Estruturada ............... 99

Anexo 2 - Termo de Consentimento Livre e Esclarecido - Experimento 102

Anexo 5 - Script em VBA-Excel, para extração das trajetórias dos

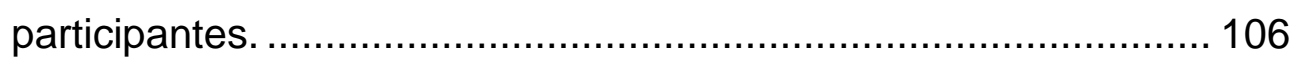

Anexo 6 - Script adaptado para VBA-Excel, para comparação das

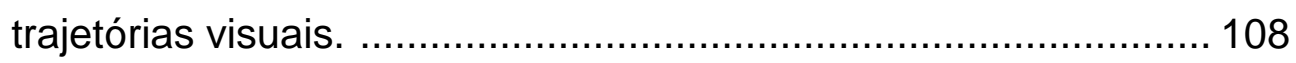

Anexo 7 - Comparação de similaridade das trajetórias de um participante (Exemplificação) .......................................................111 
Anexo 7.1. Comparação de similaridade entre as sequências da Tarefa 1 (participante X - exemplificação)

Anexo 7.2. Comparação de similaridade entre as sequências da Tarefa 2 (participante X - exemplificação)

Anexos 8 - Tabelas de visualização da porcentagem de fixações nas AOI "Vazio" por emoção 113

Anexo 8.1. Tarefa 1 113

Anexo 8.2.Tarefa 2 113

Anexos 9 - Tabelas de porcentagem de fixações nas AOI "Nariz" para cada emoção. 114

Anexo 9.1. Tarefa 1 114

Anexo 9.2. Tarefa 2 114

Anexos 10 - Tabelas para visualização da porcentagem de fixações nas AOI "Boca" por emoção. 115

Anexo 10.1. Tarefa 1 115

Anexo 10.2. Tarefa 2 115

Anexos 11. Tabelas para visualização da porcentagem de fixações nas AOI "Entre sobrancelhas" por emoção 116

Anexo 11.1. Tarefa 1 116

Anexo 11.2. Tarefa 2 116

Anexos 12 - Tabelas para visualização da porcentagem de fixações nas AOI "Testa" por emoção

Anexo 12.1. Tarefa 1 
Anexo 12.2. Tarefa 2

Anexos 13. Tabelas de visualização da porcentagem de fixações nas AOI "Olhos" por emoção.

Anexo 13. 1. Tarefa 1

Anexo 13.2. Tarefa 2

Anexos 14 - Tabelas de visualização da porcentagem de fixações nas AOls "Sobrancelhas".

Anexo 14. 1 Tarefa 1

Anexo 14.2. Tarefa 2

Anexo 15 - Porcentagem de hits nas AOls conforme sequência de fixações para as tarefas 1 (fig. A) e 2 (fig. B) - MEDO 120

Anexo 16 - Porcentagem de hits nas AOls conforme sequência de fixações para as tarefas 1 (fig. A) e 2 (fig. B) - NEUTRO. 121

Anexo 17 - Porcentagem de hits nas AOls conforme sequência de fixações para as tarefas 1 (fig. A) e 2 (fig. B) - NOJO. 122

Anexo 18 - Porcentagem de hits nas AOls conforme sequência de fixações para as tarefas 1 (fig. A) e 2 (fig. B) - RAIVA 123

Anexo 19 - Porcentagem de hits nas AOls conforme sequência de fixações para as tarefas 1 (fig. A) e 2 (fig. B) - SURPRESA. 124

Anexo 20 - Porcentagem de hits nas AOls conforme sequência de fixações para as tarefas 1 (fig. A) e 2 (fig. B) - TRISTEZA 125 


\section{Introdução}

Em nosso cotidiano, sinais não verbais de emoções são frequentemente utilizados como parte essencial da transmissão de mensagens entre indivíduos, bem como elementos complementares às mensagens verbais transmitidas. Expressões faciais, gestos, entonação, postura corporal são exemplos de mecanismos de comunicação não verbal utilizados por diferentes grupos culturais e também por espécies distintas.

É sabido que entre os diferentes sinais não verbais de expressão da emoção, as expressões faciais são aquelas com maior destaque, mediando boa parte das interações sociais e da comunicação não verbal. Através da observação da expressão alheia podem-se inferir informações sobre seu estado emocional, suas intenções e, inclusive, suas reações aos eventos apresentados em nosso ambiente (Whalen et al., 2013).

O estudo das emoções através das expressões faciais ganhou destaque ao longo dos últimos anos, desde o trabalho de Ekman e Friesen (1971), que avaliaram transculturalmente a expressão e o reconhecimento de diferentes constructos emocionais, corroborando a teoria da universalidade das emoções, proposta no trabalho pioneiro de Darwin (1872/1998). Ao longo dos anos, sucessivas pesquisas investigaram o comportamento de expressar e reconhecer categorias de emoções básicas entre diferentes populações, controlando variáveis como idade, sexo, patologias psiquiátricas e neurológicas, processos neurobiológicos subjacentes, atividades cognitivas paralelas e suplementares, entre outras variáveis.

Diferentes métodos foram utilizados ao longo dos anos para as investigações, incluindo identificação de expressões faciais, de cenas visuais 
emocionais, indução de emoção através de vídeos, música ou fotografias, acompanhamento de respostas galvânicas e de sinais autonômicos diante de uma exposição a um contexto emocional, até a utilização de métodos de neuroimagem, em busca de ativação de áreas correlatas para a atividade emocional, que, sem dúvida, são as mais utilizadas em pesquisas com emoções atualmente (Lewis, Haviland-Jones, \& Barrett, 2008).

A metodologia do rastreamento do olhar é tida como uma nova abordagem para o estudo das emoções. Embora não seja uma técnica recente, observou-se através do levantamento bibliográfico realizado que as pesquisas envolvendo reconhecimento de expressões faciais emocionais e o rastreamento do olhar ainda podem ser consideradas restritas, visto que, focam principalmente no comportamento do olhar de populações clínicas, com algum transtorno psiquiátrico ou comprometimento neurológico, sendo poucos os estudos que trabalham com populações sem patologias, de uma maneira mais abrangente. Ademais, por ser uma técnica de difícil manipulação, haja vista a quantidade de dados que gera, aparentemente, os pesquisadores optam por reduzir os tipos de movimento do olhar avaliados, quase sempre restringindo suas análises às regiões de interesse $(\mathrm{ROI})$ ou a somente pontos de fixação, aspectos relativamente estáticos do olhar (Vassallo, Cooper e Douglas, 2009).

Também não foi encontrada, na busca bibliográfica realizada, uma padronização nos métodos utilizados para a avaliação e comparação dos movimentos oculares em expressões faciais. A proposta de investigar um padrão de exploração das expressões faciais, utilizando-se da trajetória visual (visual scanpath), engloba diferentes variáveis avaliadas isoladamente em 
outros estudos, bem como, fornece um dado que captura a dinamicidade do reconhecimento das expressões faciais.

Esta tese pretende contribuir para o estudo do reconhecimento de expressões faciais, utilizando-se da metodologia de rastreamento ocular, em busca de um modelo descritivo para a trajetória visual normal realizada em diferentes tarefas de reconhecimento de expressões faciais, incluindo mais variáveis e movimentos oculares, primando pela busca de um modelo integrado de trajetória visual para cada uma das emoções faciais básicas. A hipótese primária é de que existe um padrão comum de trajetória visual para o reconhecimento das expressões faciais referentes a cada uma das emoções básicas e universais.

Assim, com os resultados desta pesquisa, propõe-se expandir os conhecimentos acerca da trajetória visual diante de estímulos emocionais, ampliando as estratégias metodológicas utilizadas até o momento. Como impacto teórico, tem-se a obtenção de um dado psicofísico que corrobore a teoria do reconhecimento de expressões faciais, e, como impacto aplicado, os dados obtidos, caso confirmada a hipótese principal, poderão ser utilizados para o treinamento sistemático, melhorando o desempenho de reconhecimento de emoções na face, através do direcionamento do olhar, seja no contexto de reabilitação de indivíduos com dificuldades no reconhecimento associadas a patologias, ou no treinamento para expertise, aprimorando a detecção de emoção por expressões faciais. 


\section{As Emoções}

O estudo da emoção data de tempos remotos no âmbito da ciência. Envolve não somente a psicologia, mas questões teóricas pertinentes à filosofia, sociologia, neurociências, entre outras. O debate surge desde a tripartição cognição-emoção-motivação de Platão, evoluindo junto com a ciência, incluindo a marcante divisão mente-corpo de Descartes, a universalidade e o evolucionismo de Darwin e a importância da percepção dos estados corporais de William James, conforme resumido por Scherer (2000), até os modelos contemporâneos de estudo das emoções, que englobam conceituações epistemológicas, reações comportamentais e fisiológicas, juntamente com correlatos cerebrais.

\subsection{Definições de Emoção}

Definir emoção pode ser considerado uma tarefa difícil dentro do contexto psicológico. Diferentes investigadores utilizam diferentes objetos e consequentemente diferentes métodos. No entanto, reportam seus resultados como se referindo ao mesmo fenômeno: emoção. Alguns se utilizam da descrição de reações corpóreas, outros a colocam no campo da avaliação de eventos interiores e exteriores, dos conceitos morais, entre outros (Pessoa, 2008).

O conceito de emoção não deve ser confundido com outros estados afetivos, como humor, atitudes, motivação, sentimento, que compõem outros constructos teóricos, embora estejam relacionados e possam interferir um no outro (Izard, 2010). 
O propósito desta tese não é encontrar uma definição de emoções, ou mesmo esgotar as possibilidades. No entanto, em meio a tantas perspectivas, cabe ressaltar a importância de se destacar qual definição de emoção está-se utilizando, haja vista a implicação na conceituação das variáveis envolvidas, na operacionalização, nos métodos e interpretação dos resultados.

Apesar das diferentes definições possíveis para emoção e suas correntes de estudo associadas (Lindquist, Wager, Kober, Bliss-Moreau, \& Barrett, 2012), e seguindo a recomendação de Izard (2010), define-se para o presente estudo que emoção é um processo de nível básico, que não pode ser completamente dissociado de outros processos cognitivos, que é compartilhado por diferentes espécies, possuindo importância e características evolutivas e que tem seu significado compartilhado através de mecanismos verbais, bem como, através de sinais não verbais de comunicação.

Emoções distintas incluem informações faciais, vocais, uma fisiologia específica associada. Cada emoção não é um único estado afetivo ou psicológico, mas sim uma família de estados relacionados, no sentido de que não são estáticos ou isolados, mas sim, modulados conforme as especificidades do momento, embora mantenham características comuns, que Ihes dão pertença àquela categoria. Todas as emoções podem ser experimentadas em um continuum de intensidade e estão sujeitas a variação individual e contextual (Ekman \& Cordaro, 2011; Ekman, 1970, 1999).

Por emoções básicas, compreendem-se respostas afetivas préprogramadas evolutivamente e de caráter universal, que seriam expressas e reconhecidas de modo semelhante por toda uma espécie, sendo constituídas de respostas fisiológicas distintas para situações de sobrevivência e 
fundamentais para a vida, que foram úteis em nosso ambiente ancestral (Tracy \& Randles, 2011). Estas respostas são universalmente compartilhadas dentro de nossas espécies e algumas podem ser encontradas em primatas e outros mamíferos. Boa parte da pesquisa realizada em emoções básicas envolve pesquisas empíricas, iniciadas em campo, e adaptadas posteriormente ao laboratório e que costumeiramente focam nas expressões faciais (Ekman \& Cordaro, 2011; Ekman, 1992; Izard, 2010).

Conforme apresentado por Ekman e Cordaro (2011), para definir uma emoção como básica, algumas características devem ser consideradas, pois costumam estarem presentes na maioria delas: são sinais universais distintos, com respostas fisiológicas autonômicas distintas; pressupõem uma avaliação automática do contexto; são compartilhadas por outras espécies, principalmente, primatas; possuem um início rápido, ocorrendo espontaneamente e podendo ser de curta duração; apresentam pensamentos, memórias e imagens distintos associados, bem como, uma experiência subjetiva distinta.

As emoções básicas, por constituírem uma forma de "programação evolutiva", não são aprendidas através da cultura ou do contexto social, embora possam sofrer sua influência. Dael, Mortillaro e Scherer (2012) ressaltam a influência de regras de exibição culturalmente definidas, que podem ser responsáveis por modificar ou inibir expressões faciais básicas, como no caso dos orientais (Matsumoto, Hwang, \& Yamada, 2010; Matsumoto, 1990).

Quando se menciona a existência de um aparato fisiológico específico, não se quer reafirmar teorias localizacionistas (Panksepp \& Watt, 2011; 
Panksepp, 2010), de que emoções específicas estariam atreladas a áreas específicas do cérebro, numa correspondência de um para um, o que seria um retrocesso científico, haja vista os conhecimentos neurobiológicos atuais. Existem especificidades neurobiológicas para os tipos de exibição de emoção (expressão facial, prosódia emocional, identificação de estímulos dinâmicos e estáticos), mas não, necessariamente, para cada uma das emoções. A ideia é da existência de conexões neuronais específicas para a regulação, expressão e reconhecimento da emoção, que não são completamente distintas de outras atividades cognitivas.

Os modelos de emoções básicas são consagrados na ciência, considerando o reconhecimento de diferentes estados emocionais em diferentes culturas, bem como na comparação entre espécies, com os seres humanos possuindo uma série de formas de expressões de emoção compartilhadas com outros animas, como o caso das expressões faciais e corporais (Darwin, 1872/1998; Hess \& Thibault, 2009). Assim, tem-se a importância evolutiva de sinais de comunicação não verbal, rápidos e visíveis em contextos sociais diferenciados, onde a comunicação verbal não pode ser utilizada.

\subsection{Tipos de Sinais Não Verbais de Emoção}

Sinais não verbais de comunicação da emoção são comuns e estão presentes em nosso cotidiano. Compreender a emoção do outro está associado a questões de relevância e competência social, como interação e empatia e sofre influência de diferentes fatores, como regras culturais (Ekman, 2003), intimidade com o outro (Ma-Kellams \& Blascovich, 2012), contexto 
ambiental e emocional (Marian \& Shimamura, 2012) e até posturas corporais (Dael et al., 2012), sendo muitos os meios pelos quais sentimos ou reconhecemos diferentes emoções.

Darwin (1872/1998) foi um dos primeiros pesquisadores em emoções básicas a alertar para a pluralidade de formas de expressão emocional, focando principalmente em expressões faciais, entonações e postura corporal, e também a investigar estes fenômenos em diferentes culturas. Ekman e Friesen (1969) prosseguiram os estudos transculturais, investigando diferentes sinais não verbais de comunicação, em busca de informações acerca de significados, funções, origens, categorizações, atribuindo às expressões faciais a função de transmitir emoções de forma universal.

Apesar de também poderem ser classificadas pelas categorias de emoções básicas, ainda não existem estudos conclusivos que apontem indícios certos de universalidade na expressão e no reconhecimento da postura corporal, do gestual (emblemas) e da prosódia emocional, sendo considerados, geralmente, como construídos culturalmente, tendo seu reconhecimento, significado e interpretação vinculados ao contexto social. No entanto, um reconhecimento bidirecional entre duas culturas (tribo himba - Namíbia e ingleses), dentro das categorias das emoções básicas, foi identificado para vocalizações emocionais como gritos, gargalhadas, murmúrios, choros, entre outros (Sauter, Eisner, Ekman, \& Scott, 2010).

Vale aqui ressaltar que, no cotidiano, os sinais não verbais emocionais não se apresentam de modo isolado e costumam interagir entre si, interferindo no reconhecimento da emoção, na maior parte das vezes facilitando o reconhecimento e interpretação dos sinais emocionais, embora também 
possam interferir negativamente, como no caso de informações incongruentes entre os diferentes estímulos (Jessen \& Kotz, 2011; Paulmann \& Pell, 2011; Regenbogen et al., 2012).

\subsection{Categorização de Emoções}

Categorizar faz parte do processo de reconhecer e classificar e também de permitir um código comum, que possibilite a interação. Influencia o modo como percebemos o nosso ambiente, como interagimos com ele e com os outros.

Quando se categoriza um estímulo, agrupam-se certos objetos ou conceitos como equivalentes ou análogos, reduzindo a complexidade de informações do ambiente externo. Ao mesmo tempo, uma grande quantidade de informação sobre o estímulo é deduzida devido a sua associação com uma categoria previamente estabelecida e armazenada mentalmente. $\mathrm{O}$ ato de categorização é, portanto, fundamental para a cognição e permite dar sentido ao mundo (Harnad, 2005).

Pensando no contexto e no cotidiano, essa categorização pode ocorrer em um continuum de intensidade e não apenas em recortes estáticos das expressões de emoção. Assim, teríamos uma sequência de processos "percepção-categorização" para os estímulos emocionais, incluindo processos bottom-up, em que o processamento perceptual de estímulos emocionais seria decomposto e se organizaria de uma forma categórica, e também processos top-down, com as categorias inatas sendo universalmente encontradas nos seres humanos e com uma influência da cultura e do aprendizado, em que as características componentes das diferentes categorias poderiam ser 
expandidas ou combinadas conforme a vivência emocional (Brosch, Pourtois, \& Sander, 2010).

Diferentes teorias sobre emoção acabam por implicar em diferentes classificações para os tipos de emoção. Até o presente momento, não existe um consenso entre quais seriam as emoções básicas. Os principais estudiosos da atualidade, que defendem o modelo de emoções básicas, dentre eles Ekman, Izard e Levinson, não apresentam um consenso absoluto sobre quais seriam estas categorias de emoção (Ortony et al., 1990; Tracy \& Randles, 2011). No entanto, as pesquisas costumam apontar, principalmente no âmbito das expressões faciais, para uma congruência no entendimento entre seis emoções básicas: alegria, tristeza, raiva, nojo, medo, surpresa. Essa divisão foi bastante divulgada por Ekman, Friesen e Ellsworth (1982), utilizando como base principal as suas descobertas transculturais referentes às expressões faciais.

De fato, existem equívocos no que diz respeito às emoções básicas, com a compreensão de que os rótulos, nomeações atribuídas a cada uma das categorias, sejam universais, quando na verdade a referência se deve ao conjunto de comportamentos, de sinais comunicativos e reações fisiológicas a determinados desencadeadores ambientais, que são experimentados e compreendidos por toda a espécie humana. Estas categorias de emoção não são estáticas e imutáveis, sendo que o contexto, a vivência e história de vida podem moldá-las, mas não criá-las. Pode-se ampliar ou diminuir a intensidade de determinada emoção, bem como os eventos associados a ela, mas não seria necessário ensinar como experimentar ou reconhecer uma situação de raiva, por exemplo. As emoções básicas seriam pré-programadas e herdadas 
na espécie evolutivamente. Então, a categorização para as emoções básicas não trataria apenas de nomeação e rótulos, mas da experiência que envolve antecedentes, uma história evolutiva, atividades neurobiológicas específicas para uma resposta adequada para aquele estímulo, mas que, por ser evolutiva, sofre interferências e adaptações ao meio (Ekman, 1999).

Como bem salientou Levenson (2011), as maneiras pelas quais pensamos sobre, falamos sobre e nomeamos nossas emoções são construídas socialmente, são amplamente determinas pelo aprendizado, pela influência social e pela cultura. Embora parcialmente fundamentada no fenômeno emocional real, a linguagem emocional é influenciada pelo costume, moral, tradição, valores culturais. A linguagem emocional pode fornecer pistas importantes sobre o fenômeno emocional subjacente, mas não pode ser considerada definitiva no julgamento do status de emoções básicas. Os valores culturais e as crenças possuem maior influência sobre as formas que as pessoas falam, pensam, e rotulam as suas experiências emocionais que sobre os aspectos comportamentais e fisiológicos da emoção em si.

Uma proposta mais ecológica e mais condizente com a ideia da evolução adaptativa é a de integração de certos aspectos dos modelos explicativos existente, utilizando-os de modo integrado, considerando os componentes básicos e as possíveis adaptações através das culturas, a moldagem pela linguagem, a influência do contexto específico, a temporalidade de apresentação dos estímulos, entre outros aspectos (Brosch et al., 2010; Gendron, Lindquist, Barsalou, \& Barrett, 2012; Marian \& Shimamura, 2012).

Assim, esta linha teórica de emoção básica (Ekman et al., 1982; Ekman, 1970, 1999; Sauter et al., 2010) foi escolhida para esta tese, 
considerando alegria, tristeza, raiva, medo, surpresa e nojo como categorias discretas, universais e essenciais, por sua popularidade, decorrente de consagração científica no estudo de expressões faciais (Ekman, 2003).

\subsection{Neurobiologia das Emoções}

Dentro do modelo de emoções básicas, na perspectiva localizacionista, a hipótese neurobiológica é da existência de circuitos específicos para cada emoção, implantados e reforçados pela seleção natural, sendo as nossas reações emocionais acionadas conforme uma programação evolutiva (Panksepp, 2010). É dentro desta perspectiva, que podemos sustentar a função específica da amígdala para o medo e as consequentes reações automáticas a possíveis estímulos aversivos no ambiente (Ledoux, 2000). Já em uma perspectiva naturalística dos modelos de emoções básicas (Ekman \& Cordaro, 2011; Ekman, 1992), pressupõe-se que as categorias emocionais básicas, como raiva, tristeza, medo, alegria, nojo, surpresa, correspondem a categorias biológicas que não podem ser reduzidas a partes psicológicas mais básicas, e que contam com o envolvimento do cérebro e do corpo em sua expressão e reconhecimento, e principalmente do sistema nervoso autônomo, contando com um sistema afetivo para cada tipo de emoção básica, como uma "programação evolutivamente pré-instalada", não existindo obrigatoriamente uma correspondência entre áreas cerebrais específicas e os sistemas afetivos (Lindquist et al., 2012).

No entanto, no âmbito da neurociência, bem como, no tocante à neurobiologia das emoções, definir áreas específicas associadas às outras emoções, pode ser um grande desafio, visto que o fenômeno em si é complexo 
e envolve diferentes processos, já que podem ser consideradas a experiência emocional, a expressão e a percepção, a construção psicológica do fenômeno, a reação evolutiva aos estímulos, entre tantos outros aspectos, envolvendo regiões subcorticais e corticais (Pessoa, 2008).

Um estímulo emocional dificilmente envolve uma única perspectiva perceptual (ex. apenas visão ou apenas audição). Na maior parte do tempo, os estímulos emocionais são multimodais, envolvendo diferentes mecanismos perceptuais, bem como outros mecanismos cognitivos.

Pessoa (2008), em seu estudo sobre a relação entre emoção e cognição, salientou esta dificuldade e propôs uma sobreposição entre o processamento da informação visual emocional e as funções executivas. Ele apontou para um sistema principal envolvido no processamento das informações emocionais e áreas secundárias, também ativas, salientando em sua hipótese a fragilidade da divisão entre cognição e emoção, considerando as áreas ativadas. As regiões emocionais centrais incluem, sub-corticalmente: a amígdala, o núcleo acumbens e o hipotálamo. Considerando a área cortical, tem-se o córtex órbito-frontal, o córtex cingulado anterior (especialmente a parte rostral) e o córtex pré-frontal ventro-medial. Já as regiões complementares incluem, sub-corticalmente: o tronco cerebral, a área tegmental ventral, o hipocampo, a matéria cinza periaquedutal, o septo e o prosencéfalo basal (incluindo o núcleo basal de Meynert). No concernente às áreas corticais: a ínsula anterior, o córtex pré-frontal, o lobo temporal anterior, o córtex cingulado posterior, o sulco temporal superior e o córtex somatossensorial. Aqui, verifica-se a extensão da atividade cerebral durante 
processamentos de informações emocionais e vale salientar que nenhuma dessas regiões pode ser considerada puramente afetiva.

Lindquist e colaboradores (2012), em uma extensa meta-análise sobre as bases cerebrais da emoção encontraram resultados interessantes. É importante ressaltar que os pesquisadores realizaram a meta-análise para questionar a perspectiva localizacionista das emoções básicas e buscar sustentáculo teórico para a sua própria teoria sobre emoções, a Abordagem do Construtivismo Psicológico. Diferentes variáveis foram utilizadas na análise, incluindo percepção e experiência das emoções básicas, tipo de tarefa, tipo de estímulo, a valência afetiva dos estímulos (positivo-negativo), entre outras variáveis. Como os próprios autores sintetizam, apesar de não serem encontrados sistemas neurobiológicos afetivos próprios a cada uma das emoções, algumas áreas cerebrais foram associadas especificamente a percepção de algumas emoções básicas, embora outras áreas se repitam em diferentes emoções como no caso do córtex pré-frontal, córtex órbito-frontal, a região occiptotemporal, que inclusive também são citadas por Pessoa (2008). Tais achados não invalidam a ideia de um "sistema afetivo" autonômico, mas não necessariamente cerebral, com padrões de reação autonômicas específicos, como defendido por Ekman e Cordaro (2011). Na tabela 1, estão relacionados alguns dos resultados mais expressivos da meta-análise de Lindquist e colaboradores (2012).

Certamente, não é possível tirar conclusões definitivas acerca dos estudos. A ciência vinha seguindo uma tendência localizacionista na abordagem das emoções, com muitos resultados corroborando esta perspectiva, principalmente devido aos estudos relacionados ao medo. No 
entanto, verifica-se uma tendência ao processamento complexo e não completamente automático, o que acaba por envolver diferentes áreas cerebrais. Tais indefinições possuem influência da dificuldade em unificar o conceito de emoção e dos múltiplos modelos e métodos existentes, o que não é necessariamente algo maléfico, mas que traduz a evolução do conhecimento dentro deste campo científico.

Tabela 1. Áreas cerebrais associadas às seis emoções básicas ª

\begin{tabular}{l|l}
\hline \multicolumn{1}{c|}{ Emoção } & \multicolumn{1}{c}{ Área cerebral } \\
\hline Raiva - Experiência * & $\begin{array}{l}\text { Insula anterior; córtex órbito-frontal inferior; córtex pré- } \\
\text { frontal ventrolateral; lobo temporal anterior. }\end{array}$ \\
\cline { 2 - 3 } Raiva - Percepção** pré-frontal ventrolateral esquerdo; córtex \\
etorrinal; córtex pré-frontal dorsomedial; córtex peri- \\
estriado; região occipitotemporal; área motora \\
suplementar.
\end{tabular}

Nota: Resultados retirados e adaptados de "The Brain Basis of emotion: a meta-analytic review" por K. Lindquist, T. Wager, H. Kober, E. Bliss-Moreau e L.F. Barret, 2012, The Behavioral and brain sciences, 35, p.139

${ }^{a}$ As informações acerca da percepção de alegria e tristeza não foram informadas. *ativação exclusiva de áreas do hemisfério esquerdo. **ativação exclusiva de áreas do hemisfério direito, com exceção do córtex pré-frontal ventrolateral esquerdo. 


\section{Reconhecimento de Expressões Faciais}

As expressões faciais fornecem uma série de informações não verbais sobre os pares, incluindo informações emocionais. É possível perceber sinais de dor, orgulho, contentamento, desprezo, entre tantos outros. Por exemplo, através do olhar, uma pessoa pode sinalizar a outra uma fonte de perigo ou para onde deveria direcionar sua atenção. Através deste mesmo olhar pode-se perceber aprovação ou reprovação ao que está sendo conversado. Expressões faciais estão sendo utilizadas, inclusive, na identificação de mentiras, sendo um campo atual proeminente de estudos, com o uso das microexpressões faciais .

Dentro do contexto de reconhecimento muitas palavras podem ser utilizadas como sinônimos, mas que, na verdade, podem evidenciar processos cognitivos diferentes, dependentes da tarefa realizada. Reconhecimento, identificação e nomeação são processos associados, estratégias utilizadas para acessar o reconhecimento, mas que não constituem, necessariamente, a mesma coisa (Brosch et al., 2010).

Ressalta-se que reconhecimento de expressões faciais é diferente de expressar emoções através da face. No reconhecimento, identifica-se determinada emoção na face de outrem, através da percepção das contrações de músculos faciais específicos daquele que vivencia a emoção (Smith \& Kosslyn, 2007). No entanto, ambos são universais e ambos podem sofrer interferências de fatores culturais, mesmo que indiretamente, como no caso do reconhecimento (ex. indivíduo "disfarça ou mascara" a emoção que está sentindo naquele momento, para evitar seu reconhecimento). 
É sabido que diferentes processos psicológicos estão associados ao reconhecimento de expressões faciais, como percepção, memória, atenção, sendo necessário compreender o processo de reconhecimento de expressões de modo multidimensional e integrado. O reconhecimento de expressões faciais envolve aspectos perceptuais, inicialmente, com identificação de características gerais da face e, posteriormente, comparações e associações com informações armazenadas na memória. Assim, para falar em reconhecimento é necessário pensar na exposição prévia a certos tipos de características componentes de uma expressão facial (Adolphs, 2002). Todavia, essa exposição não seria uma função estritamente cultural, mas sim, em parte uma marcação (imprinting) evolutiva (Darwin, 1872/1998), para permitir que os seres humanos reconheçam expressões faciais e faces com a rapidez e acurácia de um expert ao longo de diferentes culturas, embora possa ser moldada, mas não determinada por interações culturais ao longo dos anos (Calder, Young, Keane, \& Dean, 2000; McAndrew, 1986).

Uma das teorias mais proeminentes no reconhecimento de expressões faciais afirma que existem rotas diferenciadas para o reconhecimento de identidade e de expressões faciais, embora elas estejam inicialmente conectadas e a divisão ocorra apenas posteriormente, com um sistema multimodal único, embora existindo uma independência parcial. 0 reconhecimento seria feito a partir da análise de componentes principais (PCA - principal component analysis), uma teoria semelhante à utilizada para interação computador e humanos, em que características essenciais seriam extraídas da face, conforme as diferentes emoções, utilizando-se de pistas faciais específicas ( Calder \& Young, 2005; Calder et al., 2003). Talvez, seja 
possível pensar numa analogia às regiões de interesse avaliadas pelo eyetracker, regiões onde o olhar se fixaria por mais tempo ou numa maior frequência, apresentando-se como um componente principal do reconhecimento de determinada emoção. E, principalmente, pensar em termos psicofísicos, quais tipos de estratégias são utilizadas visualmente para o reconhecimento de expressões faciais emocionais.

\subsection{Teoria da Universalidade das Expressões Faciais}

Desde Darwin (1872/1998), em seu estudo sobre as expressões das emoções nos homens e nos animais, a questão evolutiva é defendida, tendo as emoções um objetivo de sobrevivência, auxiliando na comunicação e no estabelecimento de vínculos entre espécies. Acreditava-se na expressão e no reconhecimento de emoções de modo inato, visto que algumas emoções eram expressas desde o nascimento e poderiam ser reconhecidas em neonatos e não dependiam da idade para serem expressas ou reconhecidas. Em sua obra, são fornecidas sustentações a estas ideias através de expressões de emoções semelhantes entre espécies e também pelo estudo das crianças com cegueira congênita, que ainda assim apresentam expressões de emoções semelhantes a crianças não cegas, mesmo não tendo sido submetidas à modelação cultural, hipótese testada e confirmada por Matsumoto e Willingham (2009) em um estudo com atletas cegos congênitos, não congênitos e sem problemas visuais.

A teoria da universalidade das expressões faciais surge paralelamente à teoria universal das emoções. As expressões emocionais são diversas e a expressão facial emocional é um dos sinais não verbais mais utilizados rotineiramente (Biehl et al., 1997). Assim, evolutivamente, pela pressão da 
seleção natural, algumas expressões foram sendo selecionadas pelo seu valor adaptativo e de sobrevivência, principalmente no tocante à comunicação entre os indivíduos, inclusive de diferentes espécies. O reconhecimento de uma expressão facial de raiva, primitivamente, poderia indicar um ataque iminente, e sua expressão poderia auxiliar na demarcação do território e na defesa de si e do grupo. No entanto, é importante ressaltar que nem todos os movimentos faciais são considerados expressões faciais emocionais universais. Alguns foram desenvolvidos conforme a cultura e com outras finalidades comunicativas, além das emocionais (Ekman, 1994).

Muitos estudos buscaram comprovar a universalidade das expressões e do reconhecimento de emoções faciais, investigando estes estímulos entre diferentes culturas. São estudos clássicos e pioneiros (Ekman, 1994; Ekman \& Friesen, 1971; Ekman, 1972; Izard, 1994) - para citar alguns - que auxiliaram no entendimento destes processos e confirmaram a hipótese inicial postulada por (Darwin, 1872/1998).

Ekman e Friesen (1971) também apontaram esta constância entre culturas em seu estudo clássico envolvendo culturas mais isoladas, sócioeconomicamente pré-industriais, expandindo e fornecendo fundamentos empíricos de que existiriam emoções básicas compartilhadas universalmente. Certamente, uma das áreas mais estudadas nas pesquisas sobre emoções básicas envolve o reconhecimento e a expressão de faces emocionais, haja vista a facilidade de manipulação e mensuração do fenômeno.

Uma das teorias mais expressivas é a teoria neurocultural da emoção (Ekman, 1972), que postula a existência de um "programa de afeto facial" universal, que fornece um mapa correlato e específico entre a emoção que 
uma pessoa sente e a expressão facial que esta mesma pessoa indica. Segundo esta teoria, músculos faciais se alterariam especificamente para cada emoção, logo o "programa de afeto facial" é o mesmo para todas as pessoas em todas as culturas e, portanto, todos os indivíduos expressam e reconhecem emoções da mesma maneira em ambientes não-sociais (Ekman, 1994).

De acordo com Tracy e Randles (2011), existe um consenso de que as emoções básicas específicas, diferentes uma das outras, possuem componentes expressivos neurais e fisiológicos pré-fixados, associados a cada uma delas, e também um componente subjetivo, seja ele motivacional ou relacionado a sentimentos, que foi selecionado por meio de interações de longa data com estímulos ecologicamente válidos. A generalização entre espécies, ou seja, a observação de uma emoção em outros animais, também pode ser considerada como um indicador claro do aspecto evolutivo. E, como bem resumiram Jack, Garrod, Yu, Caldara e Schyns (2012) - apesar de discordarem da referida hipótese - a hipótese da universalidade prediz que, em cada cultura, os modelos mentais ("programa de afeto facial") formam seis categorias específicas de reconhecimento, uma para cada emoção básica, já que cada emoção é expressa através de uma combinação de movimentos faciais comum a todos os humanos.

De certo, a teoria da universalidade das expressões faciais emocionais não é unanimidade, apesar de ser bastante difundida. Afora os autores da teoria do construtivismo psicológico (Barrett, 2012; Gendron et al., 2012; Lindquist et al., 2012), que estendem sua concepção de construção da emoção em torno da cultura e linguagem às expressões faciais, algumas outras pesquisas preocuparam-se com a investigação específica da universalidade 
das emoções, encontrando incongruências entre culturas. Russell (1994) foi um dos primeiros pesquisadores a diretamente questionar a teoria da universalidade do reconhecimento de expressões faciais com dados, compilando taxas de acerto para cada emoção de diferentes estudos transculturais, ressaltando a dificuldade de reconhecimento diferencial entre medo e surpresa e as baixas taxas de concordância para nojo. Neste mesmo trabalho, inclusive compilou os métodos utilizados nos diferentes experimentos, apontando falhas e possíveis direcionamentos de resposta por conta dos métodos utilizados. As afirmações apresentadas foram tão contundentes que Paul Ekman (1994), revisou e rebateu cada uma das argumentações de Russel, elucidando questões sobre a influência da cultura no reconhecimento de expressões faciais, que não é ignorado ou negado, apenas não se tem a cultura como ponto inicial de reconhecimento de expressões, incluindo aprendizagem.

Nelson e Russell (2013) reavaliaram recentemente as produções transculturais e verificaram novamente a dificuldade de reconhecimento em expressões faciais negativas, com um melhor desempenho das culturas ocidentais. Vale ressaltar que o estudo é descritivo e nos permite verificar uma série de interferências culturais no processo do reconhecimento. Ainda assim, não consiste em evidência suficiente para o questionamento da teoria da universalidade, visto que, interferências culturais são reconhecidas, tais como as regras de exibição e a teoria do dialeto emocional, e também, não conseguem sustentar a afirmação de que expressões emocionais são aprendidas, visto que a taxa de precisão para a maioria delas ainda é bastante alta. 
Jack et al., (2012), em um estudo mais recente utilizaram modelação computacional 3D, com base no FACS - Facial Action Coding System (Ekman \& Rosenberg, 1997), para recriar diferentes expressões faciais básicas para ocidentais e orientais e submetê-las a avaliação de indivíduos dos dois grupos. Através de uma análise de clusters encontraram uma alta concordância para os ocidentais em cada uma das emoções básicas, mas para os orientais encontraram intrusões e sobreposição entre categorias, como surpresa-medo, raiva-medo, sendo alegria e tristeza as únicas "puras". No entanto, os métodos do estudo podem ser questionados, visto que não existe uma precisão absoluta na modelação computacional realizada através do FACS, até porque já é de conhecimento da comunidade científica que existem diferenças na expressão e no reconhecimento de expressões faciais por parte de orientais, devido a normas culturais (Biehl et al., 1997; Matsumoto, 1992).

\subsection{Interferências Culturais}

Apesar da universalidade do processo, de fato, diferentes fatores culturais e étnicos podem interferir no processo de expressão e reconhecimento de expressões faciais emocionais. A interferência, no entanto, não torna o reconhecimento em si fruto de algo cultural, mas algo que interage com as características do meio. Isto não é um paradoxo, visto que os pressupostos evolutivos apontam que fenômenos característicos da espécie e resultantes da seleção natural são também adaptados conforme a pressão do meio (Cosmides \& Tooby, 2013).

Em ambientes sociais, as pessoas conscientemente utilizam técnicas de gestão, chamadas regras de exibição (display rules), para controlar e, por 
vezes, substituir o funcionamento do programa de afeto facial universal. Estas regras de exibição podem variar entre as culturas, e elas são normas sociais que servem para intensificar, diminuir, neutralizar ou mascarar as expressões emocionais que podem ser produzidas automaticamente, ocorrendo com maior frequência em culturas que prezam pela harmonia social, como as orientais (Ekman, 1972). Estendendo a teoria neurocultural a partir da expressão para a percepção da emoção, Matsumoto (1989) argumentou que todas as pessoas em todas as culturas expressam e percebem expressões emocionais de forma semelhante, mas que, como regra social e cultural, nem sempre se deve demonstrar a percepção ou reconhecimento de determinada emoção.

Elfenbein, Beaupré, Lévesque e Hess (2007), após pesquisas transculturais, envolvendo o reconhecimento de expressões faciais (Elfenbein, Mandal, Ambady, Harizuka, \& Kumar, 2002), as diferenças encontradas entre culturas (Elfenbein \& Ambady, 2003), bem como, o treino e o aprimoramento no reconhecimento (Elfenbein, 2006), formularam uma teoria explicativa, chamada de Teoria do Dialeto para Emoção, que consiste em dizer que as expressões faciais possuiriam dialetos, assim como na linguagem, específicos em cada cultura, que poderiam facilitar o reconhecimento entre pessoas de mesma cultura, ou dificultar o reconhecimento, entre pessoas de culturas diferentes, este último configurando os dialetos. Elfenbein (2013) também salienta a existência de sotaques não verbais, que seriam pequenas alterações nas expressões que não atrapalhariam ou interfeririam na expressão e no reconhecimento de expressões faciais entre culturas distintas. Já os dialetos não verbais seriam um subconjunto destes sotaques, que impediriam 0 
reconhecimento preciso por indivíduos não pertencentes àquela cultura específica.

Assim, Elfenbein (2013) afirma que:

"É importante distinguir os dois processos interconectados na teoria do dialeto: primeiramente, membros de diferentes grupos culturais possuem diferentes estilos de geração de pistas não verbais, que são sistemáticas, mesmo quando súbitas. Este processo também é chamado de expressão, embora este termo sugira intencionalidade, ao passo que alguém pode gerar estas pistas sem tentar. Em segundo lugar, indivíduos tendem a julgar as dicas fornecidas baseados em seus estilos culturais próprios. Este processo de julgamento também é chamado de reconhecimento, embora, este termo, assim como o anterior, implique em intencionalidade, também pode ser implícito (...). De acordo com a distinção entre a expressão e o reconhecimento, a teoria do dialeto distingue entre sotaques não verbais e dialetos. Sotaques não verbais são quaisquer diferenças entre culturas distintas na aparência de uma expressão emocional. Dialetos não verbais são um subconjunto desses sotaques - a saber, os sotaques que impedem o reconhecimento preciso de um sinal não verbal (pp. 90-91) ${ }^{1}{ }^{2}$

\footnotetext{
${ }^{1}$ Tradução realizada pela autora desta tese.

${ }^{2}$ Texto original: "It is important to distinguish the two interconnected processes within dialect theory: First, members of different cultural groups have different styles of generating nonverbal cues, which are systematic even if subtle. This process is also called expression, although that term implies intentionality whereas one can also generate cues without trying. Second, individuals tend to judge other people's cues based on their own cultural style. This judgment process is also called recognition, although likewise this term implies intentionality yet can also be implicit. (...) In keeping with the distinction between expression and recognition, dialect theory distinguishes between nonverbal accents and dialects. Nonverbal accents are any difference across cultures in the appearance of an emotional expression. Nonverbal dialects are a subset of these accents - namely, the accents that also impede accurate recognition. (pp. 90-91)".
} 
É certo que existem evidências de diferenças dentro e entre grupos culturais na forma como essas emoções são vivenciadas e controladas, e as consequências destas diferenças, certamente, podem produzir alterações nos fenômenos da vida cotidiana. No entanto, deve-se ressaltar que muitos são os sustentáculos, replicações de pesquisa para a teoria das emoções básicas, sustentada pelo evolucionismo. Em nenhum momento, trata-se de rejeitar as influências culturais nas emoções. O próprio Darwin (1872/1998), mencionava a influência dos fatores culturais, considerando inclusive em um de seus princípios, a força dos hábitos. É certo que as emoções podem ser moldadas conforme regras culturais, como o fato de orientais não demonstrarem determinadas emoções em público (Matsumoto, 1990). A cultura também pode moldar a importância que damos a certos tipos de emoção ou a nossa linguagem sobre as emoções, como no fato de não existirem palavras para exemplificar certos tipos de emoção em determinadas culturas. No entanto, a ausência de palavras não suprime a experiência da emoção. Ademais, não se trata aqui da afirmação de que todas as emoções são universais, mas de que algumas delas, sendo importantes para a sobrevivência da espécie e diante das adversidades ambientais encontradas em gerações primitivas, foram naturalmente selecionadas e tornaram-se compartilhadas por todos os humanos. Portanto, não seria uma contradição dizer que a expressão de emoções é universal, apesar de existirem diferenças sutis em todas as culturas, que podem criar um desafio para uma comunicação eficaz. 


\subsection{Expressões Faciais Emocionais Básicas}

Quando Darwin (1872/1998) propôs a investigação sobre emoções universais e postulou a existência de expressões faciais universais, ele não se referiu apenas às expressões que hoje consideramos como básicas. $\mathrm{Na}$ verdade, até o presente momento, diferentes autores propõem expressões faciais básicas distintas, existindo, no entanto, uma concordância entre algumas delas (Biehl et al., 1997; Ekman, 1999; Izard, 1994; Matsumoto \& Willingham, 2009; Panksepp \& Watt, 2011). Alguns autores como Paul Ekman, por exemplo, incluíram ao longo dos anos novas expressões como orgulho e desprezo (Ekman \& Cordaro, 2011). No entanto, não existem estudos transculturais suficientes utilizando estas novas expressões, para garantir sua universalidade.

Nesta tese, serão utilizadas as expressões faciais derivadas das emocionais universais, que já foram testadas e inclusive tiveram os músculos utilizados para expressá-las, chamados de unidade de ação, descritos detalhadamente. São elas: alegria, tristeza, raiva, medo, nojo e surpresa. Como linha de base para o reconhecimento, será utilizada a expressão facial neutra, também reconhecida como uma expressão universal, embora possa ser mais bem definida como uma ausência de expressão facial (Ekman, 2003).

Estas expressões básicas foram mapeadas por Ekman e Friesen (1978), em sua pesquisa descritiva sobre como os músculos faciais (unidades de ação) são ativados durante a expressão de determinada emoção básica, sendo que cada emoção possui uma série de ativações musculares que a caracterizam como genuína e que também interferem no reconhecimento da intensidade da 
emoção. A universalidade da expressão das emoções básicas pelas unidades de ação foi testada em diferentes culturas (Ekman \& Rosenberg, 1997) e também em uma pesquisa entre espécies, comparando as unidades de ação de seres humanos com as de chimpanzés, encontrando similaridades no processo de expressão, existindo correspondência entre grupos de músculos ativados para a mimetização de determinadas expressões, embora tenha sido influenciado pela morfologia facial das diferentes espécies (Vick, Waller, Parr, Smith Pasqualini, \& Bard, 2007). As unidades de ação também são bastante utilizadas na interação homem-máquina, para desenvolvimento de modelos e softwares de reconhecimento de expressões faciais por computadores e outras máquinas interativas (Cohn, Zlochower, Lien, \& Kanade, 1999; Fasel \& Luettin, 2003; Krumhuber, Tamarit, Roesch, \& Scherer, 2012; Tracy, Robins, \& Schriber, 2009).

Expressões faciais melhor reconhecidas. Vale salientar que as expressões faciais básicas não são reconhecidas de maneira uniforme, não apresentando altas taxas de concordância para todas.

Expressões faciais em fotografias de medo e surpresa são frequentemente confundidas entre si, mesmo dentro de um grupo cultural, e ainda mais frequentemente em julgamentos transculturais. Já as expressões faciais de alegria são raramente confundidas com outras expressões faciais. Uma possível explicação para tal é que a configuração da expressão de alegria seja muito distinta das outras expressões (Elfenbein et al., 2007). Também existe a possibilidade de diferentes fatores influenciarem o reconhecimento de expressões faciais, como distratores ambientais; expressões posadas, não espontâneas, que tanto podem inflar a taxa de reconhecimento (Russell, 1994), 
quando feitas em intensidade máxima, como podem ser um fator de confusão, quando a expressão é feita sem utilizar as unidades de ação do FACS adequadas.

Ekman (1972) realizou um estudo entre diferentes culturas (Estados Unidos, Brasil, Chile, Argentina e Japão) com estímulos fotográficos diferentes, cada qual priorizando diferentes unidades de ação e encontrou, no geral, uma boa taxa de concordância para a maioria das emoções, com algumas porcentagens afetadas negativamente devido a determinadas fotografias. Em sua comparação, encontrou que Alegria era a emoção com uma maior taxa de reconhecimento, com as seguintes médias ${ }^{3}$ : 97,1\% para americanos, 91,6\% para brasileiros, 90,25\% para chilenos, 94\% para argentinos e $86,7 \%$ para japoneses. A expressão com maior dificuldade de reconhecimento pelos países foi raiva, com as seguintes médias de reconhecimento: 68,4\% para americanos, $82,2 \%$ para brasileiros, $76 \%$ para chilenos, $71,6 \%$ para argentinos e 63\% para japoneses. Apesar da uniformidade para a maioria dos resultados é interessante observar que emoções evolutivamente importantes, como o medo e a raiva, apresentaram baixas médias de taxas de reconhecimento em determinadas culturas (medo na Argentina - 68\% e raiva nos Estados Unidos $68,4 \%$ e no Japão - 63\%). No entanto, este caso específico pode ser explicado pelo baixo número de estímulos utilizados (duas fotografias), sendo que a segunda fotografia apresentou baixa taxa de reconhecimento em todos os países, podendo ser um problema no estímulo em si. Também apresentou os

\footnotetext{
${ }^{3}$ As médias das taxas de reconhecimento geral, em cada país, para cada expressão facial foram calculadas a partir das médias do reconhecimento fornecida por Ekman (1972), de cada país para cada estímulo fotográfico associado a uma emoção. Para as médias do reconhecimento por estímulo, consultar a referência mencionada.
} 
erros (trocas) mais comuns entre as expressões, como os pares surpresamedo e nojo-tristeza.

Nelson e Russell (2013), em sua atualização da revisão sistemática proposta por Russell (1994), encontraram taxas variáveis de concordância para cada emoção, em estudos entre 1992-2010. As maiores taxas de concordância de acertos são apresentadas por Alegria, com uma media geral de $90 \%$ de acerto, enquanto medo e nojo apresentam as menores taxas de concordância, com 55.3 e $56.6 \%$ de acerto respectivamente. Os autores consideram que a baixa taxa de concordância pode ser um forte indício da não universalidade das expressões. No entanto, tais taxas podem ser devidas a diferentes método e instrumentos utilizados. Além do que, vale ressaltar que boa parte das baterias existentes utiliza-se de estímulos estáticos e não espontâneos, o que pode influenciar na percepção, visto que, no cotidiano, nos utilizamos da dinâmica do movimento para determinar a expressão facial, assim como outras dicas ambientais, como o contexto, gestual e postura corporal.

\subsection{Processamentos Top-down e Bottom-up no Reconhecimento de} Expressões Faciais

No estudo das emoções, como no estudo de outros tipos de processamento de informação duas estratégias se distinguem: estratégias topdown, onde a teoria influencia a observação, dirigindo-a conforme categorias pré-estabelecidas, e estratégias bottom-up, onde o próprio estímulo fornece as informações, através de suas características, que serão processadas e incorporadas ao conhecimento pré-existente (Fernandez-Dols, 2013; Kagan, 2007). É sempre importante salientar que ambos os processos ocorrem de 
modo simultâneo, na maioria das situações de percepção, como numa combinação entre aquilo que é imediatamente percebido e as informações previamente armazenadas sobre aquele objeto ou situação visual específica. Esse processamento simultâneo caracteriza-se como um suporte evolutivo da espécie ao conhecimento do ambiente, no qual estamos inseridos, (Whalen et al., 2013).

Dentro do contexto do processamento de informação de expressões faciais emocionais, não existe um consenso sobre o tema, haja vista que poucos são os estudos envolvendo a tentativa de separação dos dois processos cognitivos. No entanto, o material existente segue a direção apontada pelos estudos com reconhecimento de faces, em que se afirma a preponderância dos processamentos top-down. Assim, a decodificação de expressões faciais envolveria mecanismos prévios de conhecimento dos padrões e características de determinada expressão facial (Lee et al., 2010; Wallbot \& Ricci-Bitti, 1993), o que vai ao encontro da teoria neurocultural (Ekman, 1972), que propõe mecanismos prévios de reconhecimento afetivo das emoções básicas, existindo uma predisposição universal para reconhecer e categorizar determinadas expressões faciais.

Alguns estudos recentes também sugerem a importância das saliências visuais das expressões faciais em seu processo de reconhecimento (Sassi et al, 2014). Para Matsumoto e Hwang (2014), o reconhecimento das expressões faciais é influenciado por características específicas, componentes visuais, por vezes relacionados à ausência ou ativação de determinados grupos musculares, como é o caso do zigomático, para o bom reconhecimento. 


\section{Rastreamento ocular}

O procedimento de rastreamento do olhar, também conhecido como eye tracking, é uma metodologia bastante utilizada dentro da ciência psicológica e ganhou bastante destaque ao ser associada a medidas de diferentes processamentos cognitivos, incluindo leitura, atenção e processamento de informações (Rayner, 1998).

Consiste no acompanhamento do movimento ocular em relação a alguma informação visual. Este rastreamento pode ser realizado através de diferentes métodos, sendo o mais utilizado, o rastreamento do movimento da pupila (Toh, Rossell, \& Castle, 2011), acompanhando assim os diferentes tipos de movimentos oculares utilizados durante a observação de uma cena ou a realização de uma tarefa, por exemplo.

\subsection{Movimentos Oculares}

Young e Sheena (1975), sistematizaram tipos de movimentos oculares, considerando as possíveis rotações no eixo horizontal, principalmente, e no eixo vertical, levando em conta também um eixo de torção ao longo do ângulo do olhar. A seguir, serão apresentadas as definições dos movimentos mais comuns e mais utilizados em situações de rastreamento do olhar, segundo esses autores.

Movimentos sacádicos. Movimentos conjugados rápidos, através dos quais se muda de um ponto de fixação a outro. Aqui estão inclusos os movimentos de fixação saltatórios, ou de "salto e descanso", observados na visualização de uma cena ou durante a leitura. Movimentos sacádicos são 
caracterizados pela elevada aceleração inicial e desaceleração final. A duração de um sacádico varia entre 20 e 40 milissegundos. Quando o movimento do alvo ultrapassa 30 graus, normalmente temos associada à movimentação da cabeça. O objetivo do sistema de movimento sacádico parece ser a fixação da imagem do alvo na fóvea.

Movimentos de perseguição. Perseguição, ou rastreamento lento, são movimentos oculares conjugados utilizados para acompanhar alvos movimentando-se lentamente. Parecem estabilizar parcialmente a imagem do alvo em movimento sobre a retina, independente dos movimentos sacádicos. Este sistema de rastreamento e busca parece ter limitações em relação à aceleração e velocidade. Movimentos de perseguição lenta geralmente não estão sob controle voluntário e normalmente requerem a existência de um campo visual em movimento para sua execução.

Movimentos compensatórios. Movimentos oculares compensatórios são movimentos suaves, intrinsecamente relacionadas com os movimentos de perseguição, que compensam o movimento ativo ou passivo da cabeça ou tronco. Eles tendem a estabilizar a imagem na retina de objetos fixos durante o movimento da cabeça.

Fixação. Também chamados de movimentos miniaturas, incluem uma variedade de movimentações, que são geralmente inferiores a 1 grau de amplitude e ocorrem durante a tentativa de fixação constante em um alvo. Aqui estão inclusos os drifts e as microssacadas, que são pequenos movimentos oculares rápidos, dinamicamente semelhantes às grandes sacadas voluntárias e que geralmente redirecionam o olho para a posição necessária para a fixação sobre o alvo. 
Já existe estabelecido a relação de determinados movimentos oculares com processos cognitivos específicos, como movimentos sacádicos indicando a modificação do ponto de atenção e a fixação como um ponto de atenção (Kowler, 2011).

Estes movimentos também são utilizados no cotidiano, pois auxiliam na localização de pontos ou objetos de interesse, como sistemas de buscas integrados e comuns aos indivíduos, e interagem intimamente com o sistema motor e vestibular, permitindo a obtenção da informação necessária para determinada ação (Land, 2006).

Trajetória visual. Trajetória visual pode ser resumidamente definida como os movimentos oculares de busca, exploração ou observação de determinada cena ou imagem, ao longo de determinado tempo. É composta de uma sequência de fixações e movimentos sacádicos, que informa o modo como o indivíduo explorou visualmente determinado estímulo visual (Tatler, Wade, Kwan, Findlay, \& Velichkovsky, 2010).

Essa trajetória visual pode ocorrer em uma situação de observação espontânea, quando o indivíduo observa uma cena ou figura sem nenhuma tarefa pré-estabelecida. Pode também ser um olhar associado a uma tarefa específica, quando a observação do indivíduo é guiada por uma questão particular ou tarefa (Yang, Dempere-Marco, Hu, \& Rowe, 2002). Assim, é sabido que o tipo de tarefa ou instrução proposta pode influenciar a direção do olhar e consequentemente a trajetória visual.

A Teoria da Trajetória Visual, proposta por Noton e Stark (1971), previa que a primeira fixação para uma imagem é muito semelhante àquelas realizadas ao reconhecer a mesma imagem em um momento posterior. De 
acordo com esta teoria, quando uma pessoa codifica uma imagem, os movimentos dos olhos são armazenados na memória como um modelo espacial. Quando eles visualizam a mesma imagem em um momento posterior, este padrão de fixações e sacadas é reutilizado para facilitar o reconhecimento da imagem (Noton \& Stark, 1971). Um problema nesta teoria é que está sustentada no fato de que as trajetórias visuais são geradas quase inteiramente por processos top-down, reduzindo a influência do processo bottom-up.

Por isso, a importância de investigar os tipos de processamento subjacentes às trajetórias visuais, atrelados a diferentes tarefas, dentro do contexto do reconhecimento de expressões faciais, visto que já existem comprovações desta influência em estudos com cenas visuais emocionais, cenas complexas, observação de objetos, tarefas cotidianas (Kowler, 2011).

\subsection{Eye Tracker}

Eye tracker é um equipamento que permite acesso à informação e dados sobre a direção do olhar de determinada pessoa, de uma maneira não intrusiva, fornecendo diferentes medidas objetivas e dados quantitativos sobre o olhar e, consequentemente, sobre o processamento visual e atencional.

O funcionamento do equipamento é dependente de um software, que realiza, através de algoritmos específicos, a correspondência entre a posição do olhar e o estímulo visual apresentado. É normalmente através destes softwares que são coletados os dados específicos referentes ao movimento dos olhos, como tempo de duração e localização (Cooke, 2005). 
Atualmente, existem diferentes modelos de eye trackers no mercado. No geral, o hardware consiste em uma ou duas câmeras LED (dependendo se o rastreamento realizado será monocular ou binocular), com emissão de luz infravermelha direcionada aos olhos, que geralmente captam o reflexo da pupila e da córnea para calcular a distância vetorial de ambos, acompanhando sua movimentação (Duchowski, 2002). O equipamento também pode ser fixo, quando montado em uma mesa ou com as câmeras diretamente acopladas a uma tela de computador, e pode contar com auxílio de aparadores para o queixo e testa, caso sejam necessárias estabilização e pouca movimentação angular da cabeça. Os equipamentos móveis apresentam-se em forma de óculos ou capacetes e são bastante utilizados em pesquisas envolvendo situações reais, em que o sujeito precisa atuar no ambiente que o cerca, como no caso de pesquisa com aviadores, motoristas ou mesmo pesquisas de rótulos e identidade visual para o marketing (Cooke, 2005).

Desenvolvimento da metodologia de rastreamento do olhar. $A$ evolução dos equipamentos e metodologias de rastreamento do olhar iniciouse no final do século XIX, tendo progredido significativamente ao longo do século passado, com o desenvolvimento de técnicas menos invasivas. Conforme classifica Duchowski (2002), atualmente, estamos na quarta geração de equipamentos para rastreamento do olhar, tendo como característica principal o desenvolvimento de aplicações interativas, sendo as três gerações anteriores assim descritas: a primeira - focada na descoberta dos diferentes tipos de movimentos oculares; a segunda - mais voltada para pesquisas aplicadas, principalmente com o uso dos pressupostos da teoria experimental e comportamental; e a terceira - voltada para o aprimoramento da metodologia, 
da mensuração e gravação dos movimentos, buscando garantir maior precisão e obtenção de dados com maior facilidade e de modo menos invasivo.

$\mathrm{Na}$ verdade, as primeiras técnicas utilizadas para acompanhamento do olhar, antes da invenção de eye trackers, eram técnicas observacionais, que se utilizavam de recursos como espelhos, telescópios, vidros e tinham a vantagem de ser pouco invasivas. No entanto, apresentavam baixa precisão e só podiam acompanhar movimentos oculares mais extensos e duradouros, visto que dependiam da observação do pesquisador para identificação e classificação do movimento ocular. Esta técnica foi utilizada até a década de 1970, no estudo com bebês e crianças, mas já com o auxílio de câmeras de vídeos, para checagem posterior da marcação do observador (Yang et al., 2002; Young \& Sheena, 1975).

O primeiro equipamento de acompanhamento dos movimentos oculares foi criado por Javal, em 1879, e consistia num híbrido entre as técnicas observacionais e as técnicas de dispositivos acoplados, pois se utilizava de um espelho para observar a leitura do indivíduo e também contava os movimentos sacádicos, através de um microfone ultrassensível posicionado em uma das pálpebras, que captava o barulho da córnea ao chocar-se com ele. Para uma localização aproximada das fixações, Javal induzia pós-imagens e pedia para a pessoa informar a localização das mesmas enquanto lia o material (Richardson \& Spivey, 2004)

Posteriormente outras técnicas foram desenvolvidas, avançando em relação às técnicas observacionais, como os dispositivos acoplados, que consistiam em artefatos acoplados ao olho, como as bobinas para esclera ("anéis" colocados em torno da esclera que registravam os movimentos nas 
direções horizontal, vertical, entre outros), a eletro-oculografia, que se utilizava de sensores para diferenças de potencial entre a parte anterior e posterior do globo ocular, acusando a direção do movimento (Holmqvist et al., 2011), e também, as lentes de contatos espelhadas, que refletiam a luz incidida diretamente sobre o olho, este último método utilizado por (Yarbus, 1967).

Atualmente, os eye trackers modernos são dispositivos ópticos, que se utilizam de metodologias não invasivas, com a projeção de luz infravermelha na superfície do olho, com a marcação e acompanhamento dos reflexos na pupila e na córnea, a gravação das imagens do olho e seu movimento ocular a uma velocidade de coleta de dados do olhar e projeção na imagem variando entre 60 e 2000hz, dependendo do equipamento e software utilizado (Tobbi Technology, 2011).

Medidas aferidas pelo eye tracker. Existem, atualmente, cerca de 120 medidas que podem ser aferidas pelo eye tracker (Holmqvist et al., 2011). Conforme estes autores, as medidas podem ser divididas em grandes grupos, a saber: medidas de movimento, que se voltam para uma gama de movimentos oculares através do espaço e as propriedades destes movimentos; medidas de posição: que informam a localização exata do local para onde o participante estaria olhando; medidas numéricas, que informam o número, proporção ou taxa de qualquer evento de movimento ocular contável; e medidas de latência, que expressam a duração entre o início de um evento e o início de um segundo evento.

Entre as medidas disponíveis, destacam-se algumas no contexto das pesquisas envolvendo expressões faciais. As regiões de interesse, ou áreas de interesse, consistem em pontos pré-determinados pelo pesquisador nas 
imagens a serem observadas. No caso da face, pode-se pensar em olhos, nariz, boca, sobrancelhas, entre outras características faciais, para serem classificadas como regiões de interesse. Vale ressaltar, que também é possível identificar regiões de interesse a posteriori, com a análise da frequência e duração de fixações em determinados pontos da imagem. As medidas de fixações mais comuns são a localização, duração e o primeiro ponto de fixação na figura. Em relação aos movimentos sacádicos, podem ser aferidas a extensão dos movimentos sacádicos (a distância entre um ponto de fixação inicial e um secundário), a frequência, a velocidade, a distribuição e concentração dos sacádicos nas imagens ou vídeos. Também podem ser reconstruídas as trajetórias visuais, unindo os pontos de fixação e os movimentos sacádicos, organizados de modo sequencial, obedecendo a cronologia de exposição ao estímulo. Estes dados podem ser obtidos e analisados individualmente ou para um grupo de participantes. Os resultados podem ser apresentados de diferentes formas gráficas, como mapas de calor (heat maps), ressaltando as áreas com maior número de fixações, ou mapas de trajetórias visuais, que consiste em fornecer a sequência de fixações e movimentos sacádicos que são apresentados para uma figura (Duchowski, 2007; Holmqvist et al., 2011; Richardson \& Spivey, 2004; Tobbi Technology, 2011; Yang et al., 2002).

\subsection{Rastreamento do Olhar e Reconhecimento de Expressões Faciais}

\section{Emocionais}

Estudos com populações clínicas. Diferentes pesquisas apontam para a dificuldade de reconhecimento de expressões faciais em diferentes 
patologias psiquiátricas e neurológicas. Tais dificuldades são bem documentadas em diferentes transtornos, tais como esquizofrenia (Williams, Loughland, Gordon, \& Davidson, 1999), autismo (Karatekin, 2007; Pelphrey et al., 2002; Rutherford \& Towns, 2008; Wilson, Palermo, \& Brock, 2012), fobia social e outros transtornos de ansiedade (Horley, Williams, Gonsalvez, \& Gordon, 2004; Olatunji, Ciesielski, Armstrong, \& Zald, 2011), doença de Parkinson (Clark, Neargarder, \& Cronin-golomb, 2010) e demência de Alzheimer (Ogrocki, Hills, \& Strauss, 2000). Boa parte dos resultados aponta para um decréscimo geral no reconhecimento de expressões faciais emocionais, e em sua maior parte com um padrão de rastreamento difuso, em que se constata uma distribuição de fixações ou movimentos sacádicos considerados inadequados, quando comparados a grupos controles (Toh et al., 2011).

Uma das metodologias utilizadas para a avaliação dos processos de reconhecimento de expressões faciais é o rastreamento do olhar, sob a hipótese de que alterações na exploração visual estivessem relacionadas com o baixo desempenho no reconhecimento de expressões faciais, o que fica evidente em boa parte das pesquisas.

Estudos com expressões faciais em indivíduos sem patologias. Até recentemente, boa parte das pesquisas realizadas com rastreamento do olhar e reconhecimento de expressões faciais estudavam determinadas populações clínicas como foco principal, principalmente o autismo e outros transtornos do mesmo espectro psiquiátrico. As informações obtidas sobre indivíduos sem patologias, frequentemente, estavam associadas aos resultados do grupo 
controle destes estudos, o que levava a informações pouco integradas e detalhadas, já que o foco eram as populações com patologias.

Boa parte do que se conhece sobre o reconhecimento universal de expressões faciais baseia-se em estudos transculturais realizados há décadas e que, por vezes, são taxados por críticos como enviesados, por utilizar tarefas de escolha forçada, fotografias descontextualizadas, pouco naturalísticas, e que tais fatores poderiam interferir nos resultados obtidos (Russell, 1994). O estudo com eye trackers oferece uma medida psicofísica no auxílio ao debate sobre a universalidade, além de identificar generalidades ou particularidades no processo de reconhecimento do olhar.

As pesquisas, conforme explicitadas a seguir, apresentam uma tendência a se utilizar do termo trajetória visual, mas na verdade investigam aspectos isolados e estáticos, como regiões de interesse e pontos de fixação.

Eisenbarth e Alpers (2011), em seu estudo com reconhecimento de expressões faciais, utilizaram como medidas o registro dos locais de fixação e suas durações. Também utilizaram uma proporção dominante, ao que eles chamaram de "proporção dominante" entre boca e olhos, em relação ao resto da face. Em todas as expressões emocionais, as fixações iniciais foram mais frequentemente direcionadas para os olhos ou boca. Em expressões faciais tristes, os participantes apresentaram a fixação inicial nos olhos, quando comparados a outras emoções. Em expressões faciais felizes, os participantes fixaram-se na região da boca por mais tempo em todas as tentativas. Para expressões de medo e neutro, ambos os olhos e a boca são igualmente importantes. No entanto, nas expressões de tristeza e raiva, os olhos receberam mais atenção do que a boca. 
Jack, Blais, Scheepers, Schyns e Caldara (2009) propuseram uma tarefa de identificação de expressões faciais para orientais e ocidentais, com a utilização de um eye tracker para registros de pontos de fixação e regiões de interesse associadas a cada uma das expressões. Os autores encontraram uma tendência nos orientais a focar mais em regiões superiores da face (olhos e parte superior do nariz) e que em todas as emoções existia uma tendência a focar na boca e no nariz para as duas culturas, embora os olhos também tenham sido visualizados (apenas em menor intensidade).

Vassallo, Cooper e Douglas (2009) compararam grupos de homens e mulheres no reconhecimento de expressões faciais. Como variáveis dependentes, foram utilizados o tempo de reação e a precisão, na classificação das seis expressões faciais básicas. Também compararam regiões de interesse pré-determinadas (olho direito e esquerdo, nariz e boca). Não houve diferença significativa na precisão das respostas, embora as mulheres tenham sido mais rápidas no reconhecimento. Em relação às informações de rastreamento visual, ambos os grupos se fixaram mais tempo na região dos olhos e os homens passaram mais tempo fixados na região do nariz e da boca, sendo o número de fixações e o tempo de duração das fixações nestas regiões significativamente superior nos homens.

Hall, Hutton e Morgan (2010) também compararam o reconhecimento entre homens e mulheres das seis expressões faciais básicas através de medidas fornecidas por um eye tracker. Os pesquisadores demarcaram três áreas de interesse (olho direito, olho esquerdo e boca) e registraram a frequência e o tempo de fixação nestas áreas, para as diferentes emoções. Também avaliaram o tempo de latência para a resposta e sua precisão. Os 
resultados mostram que as mulheres foram mais rápidas e precisas no reconhecimento de expressões faciais que os homens. Mulheres também se fixaram mais nos olhos do que os homens e foi encontrada uma correlação positiva entre o número de fixações nas regiões dos olhos e precisão das respostas.

Recentemente, a partir da utilização de um novo algoritmo de comparação de padrões de fixações múltiplas, pesquisadores afirmaram que indivíduos possuem padrões de exploração visual idiossincráticos, embora possam ser influenciados pela especificidade da tarefa. De fato, a trajetória "de identidade" individual alegada aparenta ser muito mais por conta do algoritmo apresentado, que uma característica individual (Kanan et al., 2015).

Percebe-se que mesmo todos utilizando eye trackers, os dados obtidos até o momento não incorporam o conceito de trajetória visual para as diferentes emoções básicas, restringindo-se aos aspectos mais estáticos do movimento ocular, como número e tempo de fixação. Deve-se salientar também a necessidade de dar continuidade às pesquisas nessa área, já que há divergências entre os resultados de estudos com as mesmas variáveis independentes. Cabe, então, dentro deste contexto, uma investigação mais aprofundada dos mecanismos de movimento do olhar e de trajetória visual para o reconhecimento de expressões faciais, investigando a interferência dos tipos de tarefa de reconhecimento de expressão (nomeação e julgamento) e dos tipos de emoção. 


\section{Objetivos}

\section{Objetivo Geral:}

Investigar o padrão de trajetória de exploração visual associado ao reconhecimento de expressões faciais, considerando a influência das próprias expressões faciais e das tarefas de nomeação e julgamento para 0 reconhecimento de expressões faciais, averiguando também a interação dos efeitos destas variáveis no padrão de trajetória visual.

\section{Objetivos Específicos:}

- Mapear as áreas de interesse (AOls) das diferentes expressões faciais emocionais que recebem maior atenção do observador.

- Identificar os acertos e erros, conforme o tipo de emoção e de tarefa, para averiguar a especificidade e dificuldade associada aos estímulos.

- Investigar os efeitos bottom-up e top-down no reconhecimento de expressões faciais, vinculados às tarefas propostas.

- Comparar as trajetórias visuais, para cada expressão facial, entre os indivíduos que acertaram e os que erraram as respostas. 


\section{Delineamento Experimental e Hipóteses}

\section{Delineamento Experimental}

O delineamento deste experimento é multifatorial, com uma configuração de níveis das variáveis independentes $7 \times 2$, envolvendo comparações intra e entre sujeitos, conforme as variáveis dependentes (VDs). Cada participante do grupo passou por todas as tarefas sequencialmente. Os dados foram avaliados de modo descritivo e comparativo, conforme os objetivos e as hipóteses testadas.

\section{Variáveis Dependentes e Variáveis Independentes}

A tabela 2 apresenta de forma esquematizada as variáveis dependentes investigadas e as variáveis independentes (VI) manipuladas, bem como os níveis de cada VI. O número de variáveis dependentes deve-se, em grande parte, à necessidade de medi-las para aumentar a quantidade de informação sobre a trajetória visual. As variáveis independentes são as expressões faciais (com sete níveis, relativos aos tipos de expressões faciais emocionais utilizadas) e os tipos de tarefa (com dois níveis, conforme a atividade proposta e o processo cognitivo preponderante associado). 
Tabela 2. Apresentação das variáveis dependentes e independentes do estudo.

\begin{tabular}{l|l|l}
\hline \multicolumn{1}{c|}{ Variáveis Dependentes } & \multicolumn{2}{c}{ Variáveis Independentes } \\
\hline \multirow{2}{*}{$\begin{array}{l}\text { Média de acerto para cada expressão; } \\
\text { Tempo de visualização dos estímulos }\end{array}$} & Alegria & Tipos de Tarefa \\
\cline { 2 - 3 } Áreas de Interesse ativadas (olhos direito & Tristeza & 1) Nomeação de \\
e esquerdo, nariz, boca, queixo, espaço & Medo & Faces Emocionais \\
entre sobrancelhas, testa); & Raiva & 2) Julgamento de \\
Número total de fixações; & Surpresa & Faces Emocionais \\
Trajetória Visual (visual scanpath) & Nojo & \\
& Neutra & \\
\hline
\end{tabular}

\section{Hipótese}

Existe um padrão de trajetória visual para o reconhecimento de expressões faciais emocionais, que sofre influência do tipo de face emocional e do tipo de tarefa proposta.

Previsões de resultados. Conforme a hipótese inicial, bem como os objetivos, esperava-se a obtenção de alguns resultados, como os citados a seguir:

- Existe uma diferença entre as características da trajetória visual naqueles que acertam e nos que erram;

- Algumas emoções possuem uma maior taxa de reconhecimento, com menor tempo total de exploração, menor número de AOls exploradas e menor quantidade de fixações;

- Existem AOls de maior relevância para o reconhecimento de cada uma das emoções. 


\section{Método}

Participantes. Os critérios de inclusão para a participação no estudo foram escolaridade mínima de Ensino Médio completo e faixa etária entre 18 e 45 anos. Como critérios de exclusão, considerou-se: não apresentar histórico atual ou prévio de doenças neurológicas, prosopagnosia, dificuldades de acuidade visual (salvo com a devida correção por lentes de contato/óculos), estrabismo, daltonismo, transtornos psiquiátricos, especialmente transtornos de humor, ou transtorno do déficit de atenção e hiperatividade, bem como treinamentos no reconhecimento de expressões faciais ou exposição prévia a bateria NimStim. Foram coletados dados de 61 indivíduos, com idade entre 18 e 37 anos, e escolaridade mínima de Ensino Médio completo. Os dados de cinco participantes foram descartados por baixa precisão no rastreamento do olhar ou por encaixar-se em algum dos critérios de exclusão.

A idade média dos participantes foi de 26,5 anos $(\mathrm{dp}= \pm 5,51)$, sendo $46,4 \%$ do sexo feminino e $54,6 \%$ do sexo masculino (ambos os gêneros ocorrem com igual probabilidade, conforme o teste binomial de uma amostra, $\rho=-0,401 ; s i g=0,688)$. No que concerne à escolaridade predomina o ensino superior incompleto, como apresentado no gráfico 1. Tal predominância justifica-se pela faixa etária escolhida, bem como o ambiente de recrutamento dos participantes e realização do experimento (Universidade Federal do Ceará). 


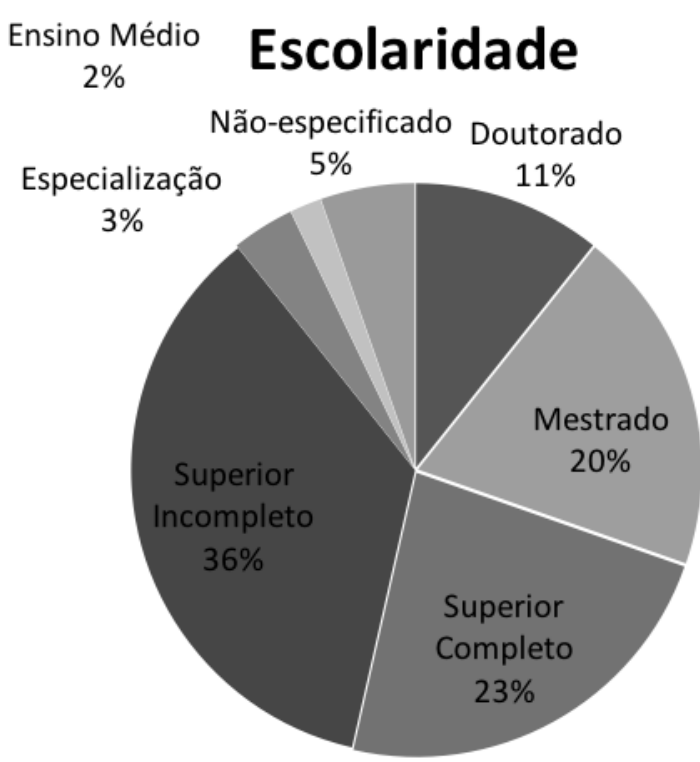

Figura 1. Distribuição percentual da escolaridade da amostra.

Instrumentos. Para a verificação dos critérios de inclusão e exclusão e coleta de informações de identidade e dados demográficos, uma entrevista estruturada, criada pela pesquisadora, foi conduzida (Anexo 1). O Termo de Consentimento Livre e Esclarecido (TCLE) também foi assinado (Anexo 2).

Estímulos para o experimento. A NimStim Set of Facial ExpressionNimstim $^{4}$ (Tottenham et al., 2009) é uma coletânea de 672 fotografias de oito expressões faciais, a saber: alegria, tristeza, medo, raiva, surpresa, nojo, neutro e calmo, sendo as sete primeiras consideradas expressões faciais universais básicas (Ekman \& Cordaro, 2011). Os participantes eram 43 jovens atores profissionais, de ambos os sexos, e de diferentes etnias (africanos, asiáticos, latino-americanos e europeus). Esta bateria foi escolhida pela grande quantidade e variedade de estímulos para cada uma das emoções, por ser recente e atualizada e por buscar características de validade ecológica, com

\footnotetext{
${ }^{4}$ A autorização de uso foi obtida diretamente com a autora, Nim Tottenham, que permitiu o uso para fins de pesquisa, com restrições na divulgação dos estímulos. A única figura utilizada neste manuscrito foi pré-determinada pela autora da bateria.
} 
instruções de posar naturalmente, de modo a minimizar os efeitos de treinos profissionais prévios, técnicas de atuação, entre outros fatores alheios. No presente experimento, foram utilizados 60 estímulos da NimStim, adaptados para a população brasileira (quatro para treino prévio durante as instruções e 56 para o experimento). Em cada figura foram demarcadas sete AOls semanticamente: testa $(\mathrm{Te})$, sobrancelha direita (SD), sobrancelha esquerda (SE), olho direito $(\mathrm{OD})$, olho esquerdo $(\mathrm{OE})$, entre sobrancelhas $(\mathrm{ES})$, nariz(N) e boca(B) (Figura 2). Tal demarcação foi baseada em regiões anteriormente identificadas como importantes para o reconhecimento de expressões faciais bem como nas unidades de ação previamente estabelecidas como importantes nos processos de expressão e reconhecimento de emoções através da face (Ekman \& Rosenberg, 2005). A categoria "calmo" não foi utilizada, por não ser uma expressão facial universal básica e por apresentar uma baixa taxa de concordância de resposta.

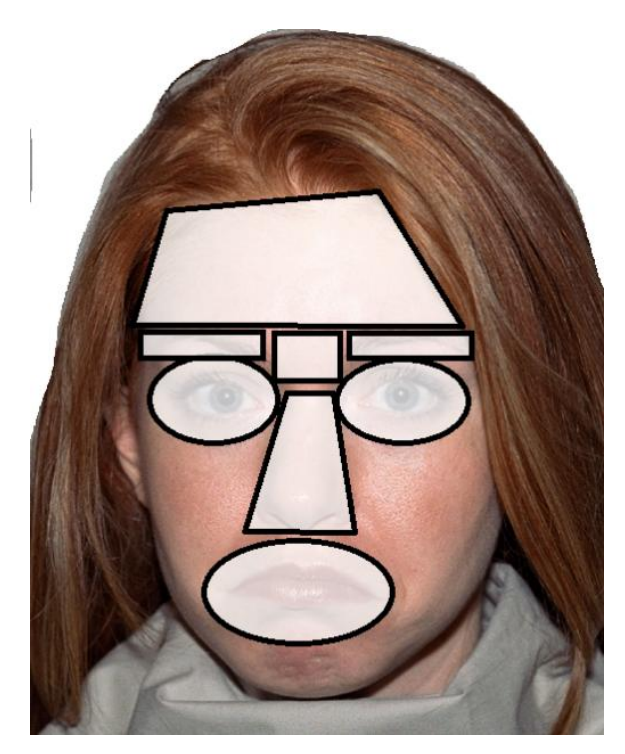

Figura 2. Exemplificação da marcação de AOls nas fotografias de expressões faciais. Fotografia adaptada da bateria NimStim (Tottenham, 2009). Figura reproduzida com autorização. 
Equipamentos. Para a apresentação das tarefas e acompanhamento do olhar foi utilizado Tobii T120 Eyetracker binocular, que permite o rastreamento do olhar em tempo real, através do acompanhamento da pupila de ambos os olhos. Com o auxílio do software Tobii Studio foi possível montar os experimentos, considerando a apresentação dos estímulos e o tempo das respostas, coletar as respostas dos participantes e realizar parte da análise dos dados.

Procedimentos. A presente pesquisa foi submetida previamente à Plataforma Brasil (CONEP), CAEE 22633114.9.0000.5540, obtendo aprovação para sua realização, conforme parecer 606.229.

Os participantes foram recrutados através de busca ativa direta e indireta, por listas de e-mail institucionais, afixação de cartazes nos departamentos da universidade, bem como por indicação de outros participantes.

O experimento foi realizado no Departamento de Física da Universidade Federal do Ceará, em uma sala com disposição adequada, onde se encontra a estrutura experimental do Tobii T120 Eyetracker. Buscou-se minimizar os efeitos de distratores visuais e acústicos, eliminando da sala de aplicação objetos que pudessem desviar o olhar e primando pelo silêncio no ambiente experimental. 

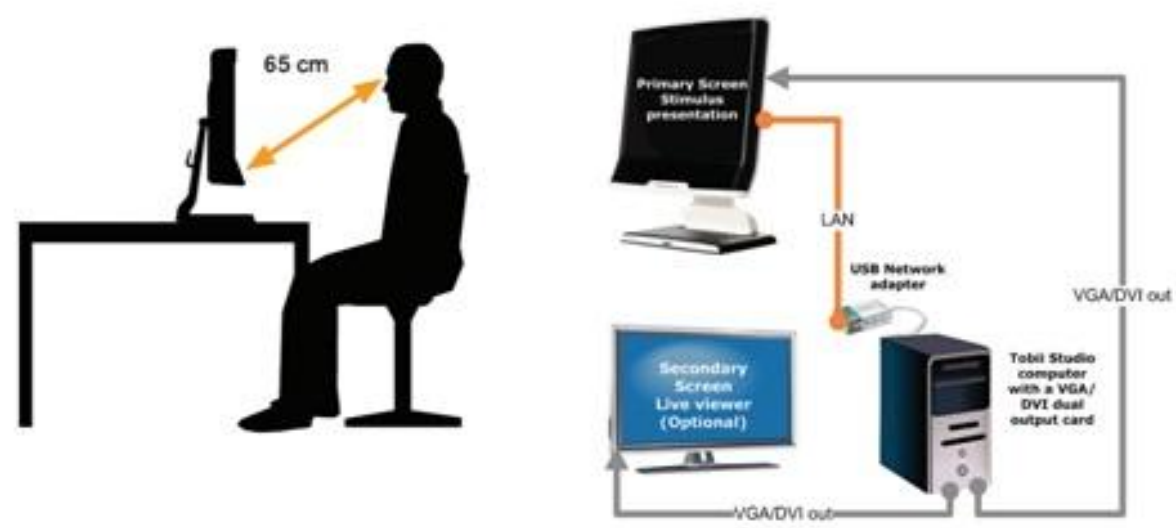

Figura 3. Exemplo de setting básico, utilizado para o rastreamento do olhar, constando do Tobii T120 Eyetracker (monitor preto), ligado a um computador Tobii Studio pré-configurado. O experimentador pode monitorar o experimento e os movimentos oculares do participante em tempo real, através de um monitor secundário (monitor azul). Adaptado de "Tobii T60 \& T120 Eye Tracker: a user guide", por Tobii Technology, 2011. 2011 Direitos autorais por Tobii ®Technology.

O procedimento iniciou-se com uma breve explicação do experimento, seguida da leitura conjunta e assinatura do TCLE (Anexo 2). Posteriormente, foi conduzida a entrevista inicial (Anexo 1), objetivando coletar dados sóciodemográficos, confirmar os critérios de inclusão e investigar preliminarmente possíveis critérios de exclusão. Confirmada a aptidão para participação das tarefas, os participantes foram posicionados diante do eye tracker, seguindo-se a calibração do equipamento para ambos os olhos e início do experimento.

O experimento era composto por duas tarefas de reconhecimento de expressões faciais. Ambas possuíam uma série de fotografias, as quais 0 participante deveria observar e responder, conforme a instrução fornecida previamente. Um pré-teste foi realizado para ambas as tarefas, com dois itens 
cada, de modo a familiarizar o participante com a estrutura dos experimentos, os procedimentos e o tipo de resposta esperado.

Tarefa 1 - Nomeação. Na primeira tarefa, o participante deveria observar diferentes faces emocionais e escolher o mais rápido possível, entre as opções fornecidas, o nome da emoção correspondente (Instruções completas - Anexo 3). Foram apresentadas 28 expressões faciais, sendo quatro estímulos por emoção, realizados por atores diferentes, para evitar efeitos de aprendizagem e de confusão em relação à identidade do estímulo. Após as instruções iniciais em tela, cada face era observada livremente. No entanto, o participante era orientado a identificar a emoção o mais rápido possível, clicando em seguida no mouse. Em seguida, uma tela de fundo escuro aparecia, com as opções de resposta (alegria, tristeza, raiva, medo, nojo, surpresa e neutro), sucedendo-se de outro estímulo. A sequência de apresentação dos estímulos foi estabelecida de modo aleatório, sendo a mesma para todos os participantes.

Tarefa 2 - Julgamento. Nesta segunda tarefa, o nome de uma emoção era fornecido em tela, antes da exibição da expressão facial e o participante respondia se o estímulo visual apresentado correspondia à emoção mencionada inicialmente. O participante deveria observar a fotografia o mais rápido possível e clicar no mouse, ao que se seguia a tela de resposta, onde ele deveria responder a uma pergunta, do tipo sim/não, se a fotografia correspondia ou não a emoção mencionada inicialmente (Instruções completas - Anexo 4).

Foram apresentadas 28 figuras diferentes daquelas do primeiro experimento, sem limite de tempo, sendo quatro de cada emoção (alegria, 
tristeza, medo, raiva, surpresa, nojo e neutro), dois estímulos correspondentes e dois não correspondentes. O participante deveria identificá-la o mais rápido possível, sinalizando com um clique no mouse, e passando para a tela de respostas, na qual constavam as opções de resposta ("sim" e "não").
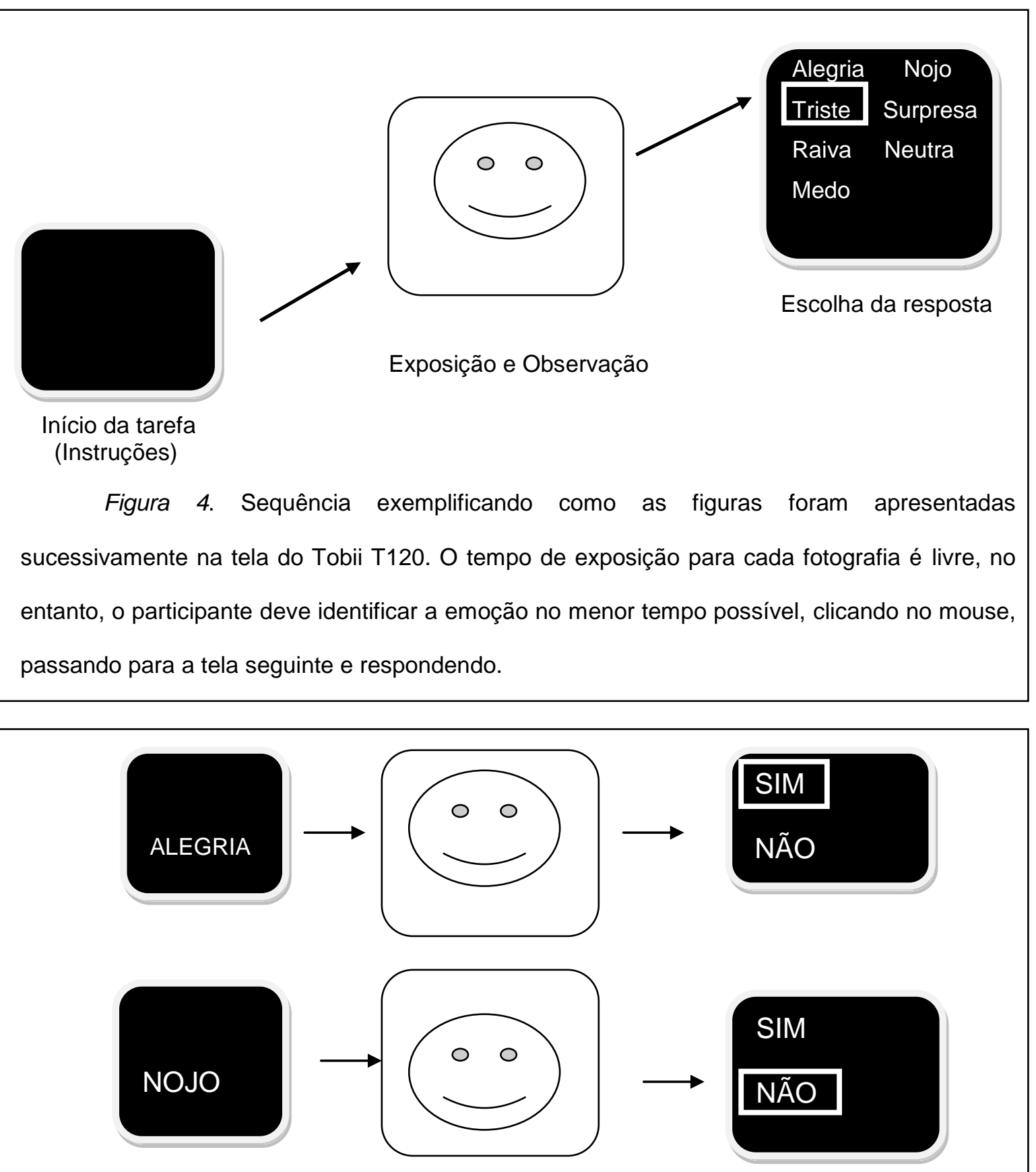

Figura 5. Exemplificação do design da Tarefa 2. Conforme a indicação emocional fornecida previamente, o participante julgou afirmativa ou negativamente a correspondência entre a emoção mencionada e a apresentada na tela. 
Assim, as etapas do experimento podem ser resumidas na seguinte sequência: 1) Apresentação introdutória ao experimento; 2) Leitura conjunta do TCLE e assinatura do mesmo; 3) Preenchimento da Entrevista estruturada; 4) Acomodação e apresentação do participante ao eyetracker; 5) Calibração; 6) Instruções, treino e início da tarefa 1; 7) Finalização da tarefa 1 e pausa; 8) Instruções, treino e início da tarefa 2; 9) Finalização da tarefa 2 e do experimento; 10) Comunicação dos resultados do participante; 11) Feedback dos participantes sobre o experimento (Figura 6).

Todas as etapas foram realizadas em um único encontro, com duração média de 35 minutos. As tarefas do experimento não possuíam duração prédefinida, por serem conduzidas conforme o tempo de reação de cada participante aos estímulos, mas em média não ultrapassaram a duração de 10 minutos.

Pré-Experimento

(aprox. 10 mins)

- Introdução

- TCLE

- Entrevista

\section{Experimento}

(aprox. 15 mins)

- Calibração

- Treino T1

- Tarefa 1

- Treino T2

- Tarefa 2
Pós-Experimento

(aprox. 10 mins)

- Resultados

- Feedback

Figura 6. Linha do tempo das etapas componentes do experimento 


\section{Análise dos Resultados}

De modo a responder as proposições iniciais, utilizaram-se como medidas os erros e acertos da amostra por tarefa e por tipo de emoção, bem como das emoções mais confundidas entre si; o tempo total de execução das tarefas e de reação a cada estímulo proposto e o total de fixações por experimento e por emoções. Tais dados foram comparados através de comparação entre médias (teste te ANOVAs).

Para a formulação da trajetória, foram utilizadas as fixações de cada participante, em cada estímulo, de cada tarefa, em cada uma das AOls previamente demarcadas Para tanto, foi necessário, inicialmente, o tratamento do banco de dados e a criação de um script, com algoritmos para a transposição das respostas de cada participante em uma trajetória (Anexo 5). Assim, as fixações soltas de cada indivíduo, nas AOls, eram encadeadas em um código, formando uma sequência de letras ou uma string. Ex: Participante, durante a visualização de um dos estímulos de "Alegria", realizou três fixações nas áreas de interesse - a primeira na região "ES" e as duas subsequentes na região "N". Sua string resultante seria D-E-E, conforme codificação prévia das AOls, em letras específicas.

Para fins de cálculo de similaridade, a trajetória foi posteriormente restrita às 10 primeiras fixações nas AOls semanticamente escolhidas. A restrição na quantidade das fixações para análise deve-se à simplificação da trajetória para análise, baseada na literatura científica, que sugere que acima do valor anteriormente citado, ocorre a reinspeção da imagem, não mais identificação ou reconhecimento (Liversedge, Gilchrist \& Everling, 2011). De 
modo a avaliar a similaridade intrínseca das trajetórias visuais de cada participante, utilizou-se o algoritmo da Distância de Levenshtein, numa versão adaptada e implementada para linguagem VBA, do Microsoft Excel (Anexo 6). O script deste algoritmo gerou uma matriz para cada indivíduo, com a comparação entre as trajetórias produzidas para cada um dos estímulos visualizados, nas duas tarefas (ver exemplo no Anexo 7), totalizando duas tabelas por participante (tarefa 1 e tarefa 2), num total de 112 tabelas (ver exemplificação na tabela 3). Por último, as médias das diferenças das similaridades para cada indivíduo foram calculadas nas duas tarefas e comparadas estatisticamente (Teste $t$ ).

O algoritmo da distância de Levenshtein ou de distância de edição é um algoritmo tradicional, que permite a comparação entre duas sequências de caracteres e fornece um valor resultante do número de edições necessárias, sejam elas adições, subtrações e substituições de caracteres, para que uma string possa ser transformada no outro. O valor da distância de Levenshtein representa o quão distante uma sequência é da outra, ou seja, a não similaridade. Assim, um valor igual à zero, indica que as sequências de caracteres são idênticas. Um valor próximo à zero indica bastante similaridade. O valor máximo é indicado pelo número de caracteres da maior sequência. Quanto maior o valor, mais diferentes são as duas sequências.

Este algoritmo possui algumas críticas, quando se busca avaliar a trajetória visual, haja vista que permite a inclusão apenas de informações sobre a localização espacial (AOls fixadas) e localização temporal (distribuição das AOls fixadas na linha do tempo, não permitindo a inclusão de outras medidas, como a duração das fixações ou dos movimentos sacádicos). No entanto, sua 
utilização é considerada suficiente e adequada quando se considera a trajetória como a sequência temporal de fixações em AOls semânticas, como é o caso das AOls nas expressões faciais (Mathôt, Cristino, Gilchrist \& Theeuwes, 2012)

Programas utilizados. Foram utilizados os seguintes softwares: Tobii Studio, para a visualização inicial, aplicação de filtros e tratamento dos dados brutos (raw data) para exportação; Excel 2010, para importação, tabulação, classificação dos dados, geração e codificação das trajetórias e comparação de similaridade e o SPSS, para os cálculos e testes estatísticos necessários. 


\section{Resultados}

Esta tese buscou identificar a existência de um padrão de trajetória visual no reconhecimento de expressões faciais emocionais, bem com a interferência do tipo de atividade cognitiva proposta (predominantemente bottom-up ou top-down) e das emoções básicas. Para tanto, avaliou e comparou informações acerca dos acertos e erros nos diferentes estímulos, o tempo de execução das tarefas, a quantidade de fixações realizadas, a frequência e distribuição de fixações nas AOls pré-determinadas para cada tipo de emoção, para as diferentes tarefas, bem como, a média da similaridade entre as trajetórias realizadas pelos participantes. Com tais medidas, buscouse avaliar os efeitos das emoções e das tarefas nos componentes das trajetórias visuais.

Em relação ao tempo de execução das tarefas não houve diferença significativa entre elas, com $t(110)=1,080$, sig $=0,283$, com médias de $3 \mathrm{~m}: 49 \mathrm{~s}$, para a tarefa $1 \mathrm{~m}$ e $3 \mathrm{~m}: 38 \mathrm{~s}$, para a tarefa 2 . Considerando o tempo de visualização dos estímulos (tempo de reação), na tarefa 1, o tempo médio foi de 1,7 segundos $(d p=1,2)$ por estímulo, sendo o mínimo 0,5 segundos e 0 máximo de 5,7 segundos. Já na tarefa 2 , o tempo médio de visualização de cada estímulo foi de 1 segundo ( $d p=0,5)$, sendo o mínimo 0,35 segundos e o máximo 2,9 segundos. Houve diferença significativa (tabela 3) entre os tempos de visualização de cada estímulo, considerando o tipo de tarefa, com um maior tempo de visualização para os estímulos da tarefa 1 , com $t(55)=7,547$, $s i g=0,00$, mas não houve diferença significativa para o tempo de visualização 
de estímulos entre emoções na mesma tarefa. Assim, por exemplo, a diferença entre o tempo de visualização do medo e da alegria, na tarefa 1 , não foram consideradas significativas.

Tabela 3. Comparação do tempo de visualização dos estímulos entre os pares de emoções nas Tarefas 1 e 2

\begin{tabular}{llrrrr}
\hline & & médias & $\mathrm{t}$ & $\mathrm{df}$ & Sig. \\
\hline Par 1 & Raiva T1 & 1,6 & 5,963 & 55 & $p<0,001$ \\
& Raiva T2 & 0,98 & & & \\
Par 2 & Tristeza T1 & 1,69 & 4,686 & 55 & $p<0,001$ \\
& Tristeza T2 & 1,1 & & & \\
Par 3 & Surpresa T1 & 1,6 & 4,719 & 55 & $p<0,001$ \\
& Surpresa T2 & 1 & & & \\
Par 4 & Nojo T1 & 1,65 & 4,337 & 55 & $p<0,001$ \\
& Nojo T2 & 0,99 & & & \\
Par 5 & Neutro T1 & 1,87 & 4,673 & 55 & $p<0,001$ \\
& Neutro T2 & 0,93 & & & \\
Par 6 & Medo T1 & 2,1 & 5,061 & 55 & $p<0,001$ \\
& Medo T2 & 1,25 & & & \\
Par 7 & Alegria T1 & 1,44 & 2,641 & 55 & $p<0,001$ \\
& Alegria T2 & 1,1 & & & \\
\hline
\end{tabular}

$\mathrm{Na}$ avaliação dos erros e acertos, conforme os resultados da ANOVA two-way, foi possível visualizar diferenças significativas entre as médias de acertos nas duas tarefas, com $F(1)=13,113, p<0,005$, com média de acerto superior para a tarefa 1 ( $m=94,32 \%$ de acerto total), de componente cognitivo predominantemente bottom-up. O efeito das emoções na taxa de acerto também pode ser observado, com $F(6)=8,524$, sig $<0,005$. As diferenças entre as médias podem ser observadas na tabela 4, com a descrição das médias por emoção em cada tarefa, bem como a média total de acertos por tarefa e no experimento. A interação entre as variáveis independentes também foi 
significativa, com $F(6)=10,056$, sig $<0,005$, ou seja, as emoções apresentam resultados diferentes conforme a tarefa proposta.

Tabela 4. Médias de acertos por Tarefas e Emoções.

\begin{tabular}{llcc}
\hline Experimento & Emoção & Média & DP \\
\hline Tarefa 1 & Alegria & 98,66 & 0,11521 \\
Medo & 78,13 & 0,41432 \\
Neutro & 95,98 & 0,19682 \\
Nojo & 97,31 & 0,16217 \\
Raiva & 97,77 & 0,14806 \\
Surpresa & 98,21 & 0,13273 \\
& Tristeza & 94,2 & 0,23433 \\
Total T1 & 94,32 & 0,23153 \\
Tarefa 2 & & \\
& Alegria & 91,96 & 0,27245 \\
& Medo & 91,96 & 0,27245 \\
& Neutro & 91,52 & 0,27924 \\
Nojo & 90,18 & 0,29827 \\
Raiva & 89,73 & 0,30422 \\
& Surpresa & 91,96 & 0,27245 \\
& Tristeza & 89,73 & 0,30422 \\
& Total T2 & 91,01 & 0,28616 \\
& Alegria & 95,31 & 0,21161 \\
& Medo & 85,04 & 0,35703 \\
& Neutro & 93,75 & 0,24233 \\
& Nojo & 93,74 & 0,24259 \\
& Raiva & 93,75 & 0,24233 \\
& Surpresa & 95,09 & 0,21633 \\
& Tristeza & 91,96 & 0,27215 \\
& & 0,26078 \\
\hline
\end{tabular}

É possível verificar claramente o efeito da tarefa ao visualizar a Figura 7. Nela, percebe-se uma menor taxa de acerto na Tarefa 2 , em todas as emoções, com exceção do medo, que possui uma taxa de acerto de $78 \%$ na tarefa 1, inferior a sua taxa de reconhecimento de $91 \%$ na tarefa 2 (Tabela 7 ). O medo é a emoção com a menor taxa de acerto na tarefa 1 , seguido da tristeza. Já na tarefa 2, o medo possui alta taxa de reconhecimento, e raiva e 
tristeza são as emoções com menores taxas. Considerando a média total de acertos, Alegria é a emoção melhor reconhecida, e medo a que apresenta mais dificuldade.

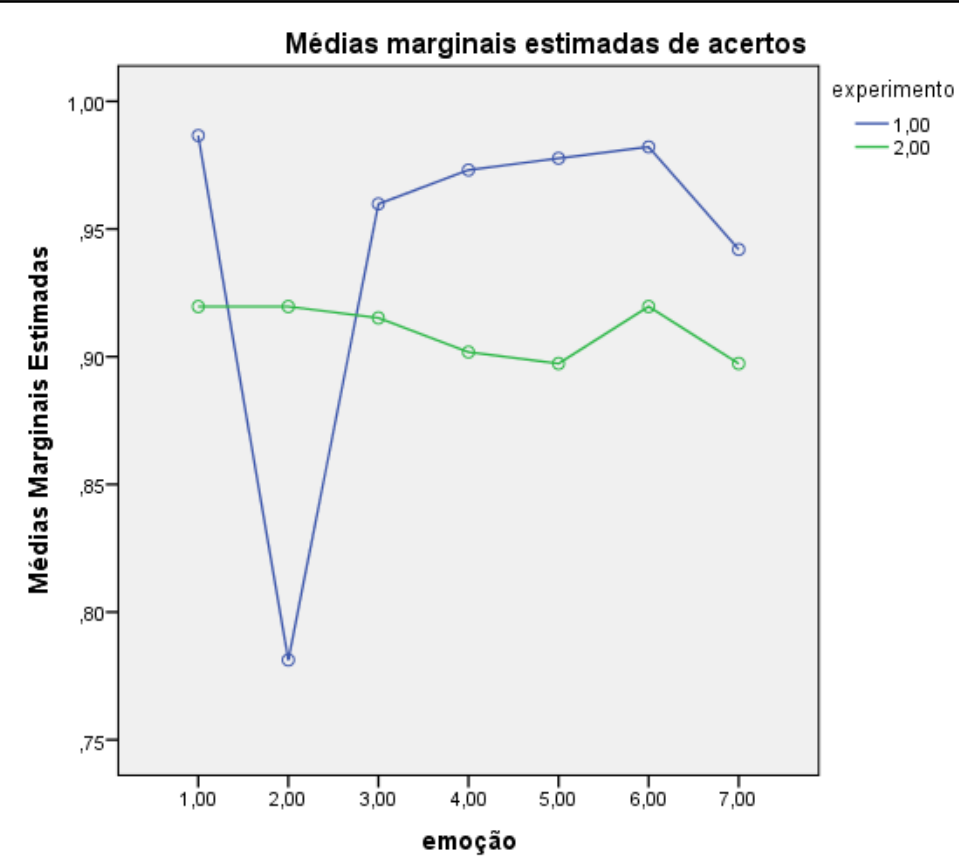

Figura 7. Gráfico apresentando as médias estimadas, conforme as diferentes emoções (1. Alegria, 2. Medo; 3. Neutro; 4. Nojo; 5. Raiva; 6. Surpresa; 7. Tristeza) e as tarefas propostas (tarefas 1 e 2 ).

Assim, é possível perceber que, com exceção do medo, todas as emoções possuem taxas de acertos razoavelmente estáveis, com pequenos desvios-padrão. De modo que, ao se avaliar a influência da emoção na média de acertos, verifica-se que a significância estatística do efeito é catalisada pela discrepância na taxa de acertos do medo. Tal afirmação pode ser verificada a partir dos valores de significância da ANOVA de comparação entre os possíveis pares de emoção $(T 1+T 2)$, que sinalizam significância apenas para as comparações com o medo. Ou seja, a diferença estatisticamente significante para as médias dos acertos entre emoções é explicada apenas pelo medo, 
com sig $=0,00$ em todas as comparações, conforme apresentado na Tabela 5. Assim, excluindo-se o medo, as outras emoções não influenciaram a taxa de acertos.

Tabela 5. Índice de significância da comparação entre as médias (ANOVA) dos acertos entre os pares de emoção.

\begin{tabular}{rccccccc}
\hline & Alegria & Medo & Neutro & Nojo & Raiva & Surpresa & Tristeza \\
\hline Alegria & - & & & & & & \\
Medo & $0,00^{*}$ & - & & & & & \\
Neutro & 0,362 & $0,00^{*}$ & - & & & & \\
Nojo & 0,362 & $0,00^{*}$ & 0,997 & - & & & \\
Raiva & 0,362 & $0,00^{*}$ & 1 & 0,997 & - & & \\
Surpresa & 0,896 & $0,00^{*}$ & 0,434 & 0,432 & 0,434 & - & \\
Tristeza & 0,051 & $0,00^{*}$ & 0,297 & 0,299 & 0,297 & 0,068 & - \\
\hline
\end{tabular}

Nota: * A diferença média é significativa para o nível $<0,05$

$\mathrm{Na}$ avaliação dos erros, é possível perceber que o principal fator de confusão é a avaliação do par medo-surpresa (Tabela 6), no qual o estímulo visual "medo" foi julgado 37 vezes, em 224 tentativas, como sendo "surpresa". Este efeito ocorreu principalmente nas primeiras visualizações do estímulo de medo, antes da visualização de um estímulo de surpresa. A tarefa 1, por ser de livre inspeção e decisão, influenciada primordialmente pelo estímulo visual (bottom-up), influenciou nestas escolhas equivocadas.

Já na avaliação dos erros para a tarefa 2, tem-se uma peculiaridade, a diferença entre os erros dos estímulos congruentes e incongruentes. Os estímulos congruentes são aqueles em que o nome da emoção condiz com a face apresentada. Nos incongruentes, o nome da emoção é diferente da 
expressão facial que se segue. Nesses casos, foram 131 erros para as emoções congruentes e 10 erros para as emoções incongruentes. Isto quer dizer que os participantes tiveram mais sucesso em julgar a emoção como diferente do nome, que como sendo a mesma. A preponderância dos erros nos pares congruentes deve-se provavelmente à mimetização da liberdade de escolha oferecida pela tarefa 1 e do forte efeito top-down dos estímulos incongruentes, já que o contraste fornecido facilitou a decisão. Considerando as emoções, para os estímulos congruentes, foram 15 erros nas expressões de Alegria, 17 nas de Medo, 19 nas faces Neutras, 21 no Nojo, 22 na Raiva, 18 na surpresa e 19 na tristeza. Já para os estímulos incongruentes, foram três erros para as expressões de Alegria, um erro para a de Medo, um para de Nojo, um para de raiva e quatro para tristeza.

Tabela 6. Frequência dos pares de trocas entre as emoções (erros) para a Tarefa 1.

\begin{tabular}{lrrrrrrr}
\multicolumn{1}{c}{ Resposta } & ALEGRIA & TRISTEZA & RAIVA & MEDO & SURPRESA & NOJO & NEUTRO \\
\hline Estímulo & 0 & 1 & 0 & 0 & 1 & 0 & 1 \\
\hline ALEGRIA & 0 & 0 & 0 & 7 & 3 & 1 & 2 \\
TRISTEZA & 0 & 0 & 0 & 4 & 1 & 0 & 0 \\
RAIVA & 0 & 1 & 0 & 0 & 37 & 8 & 2 \\
MEDO & 0 & 0 & 0 & 4 & 0 & 0 & 0 \\
SURPRESA & 0 & 2 & 0 & 4 & 0 & 0 & 1 \\
NOJO & 0 & 2 & 4 & 1 & 1 & 0 & 0 \\
NEUTRO & 1 & 2
\end{tabular}


Para a comparação entre média dos números das fixações, considerando os fatores "Tarefa", "Emoções" e a interação entre eles, utilizouse a Análise Fatorial com um único fator (Tabela 7). Verificou-se o efeito de interação entre as tarefas desempenhadas e as emoções.

Tabela 7. ANOVA para influência das VIs na quantidade de fixações.

\begin{tabular}{lrrr}
\hline Variáveis & gl & \multicolumn{1}{c}{$\mathrm{F}$} & \multicolumn{1}{c}{ Sig. } \\
\hline Tarefa & 1 & 16,29 & $\mathrm{p}<0,01$ \\
Emoções & 6 & 20,896 & $\mathrm{p}<0,01$ \\
Experimento x Emoções & 6 & 8,599 & $\mathrm{p}<0,01$ \\
\hline
\end{tabular}

A partir da comparação entre as médias (Tabela 8) é possível verificar uma maior média de fixações por estímulos na Tarefa 1 que na Tarefa 2, bem como um número maior de fixações para todas as emoções na Tarefa 1 , que na tarefa 2. O reconhecimento do Nojo exigiu um maior número de fixações, na tarefa 1 e na tarefa 2, em relação às demais emoções. O reconhecimento da surpresa, na tarefa 1, exigiu apenas 4 fixações para ser realizada, em contrapartida ao reconhecimento do medo, que exigiu 19 fixações. Tal fato pode ser explicado pelo fato de que algumas expressões de medo apareceram antes de qualquer uma de surpresa, obrigando os participantes a decidirem se era medo ou surpresa, sem a possibilidade de comparação com a surpresa. Ao chegar o momento de responder sobre os estímulos de surpresa, os participantes já haviam visualizado o medo, possibilitando a comparação e uma escolha com menor esforço cognitivo. 
Tabela 8. Comparação entre as médias do número de fixações nos experimento e emoções.

\begin{tabular}{rrrr}
\hline Experimento & Emoções & Média & \multicolumn{1}{l}{ DP } \\
\hline Tarefa 1 & Alegria & 17,3036 & 10,26188 \\
& Medo & 19,8214 & 11,37638 \\
& Neutro & 18,8214 & 8,41234 \\
Nojo & 23,3214 & 13,96503 \\
Raiva & 13,8393 & 7,57214 \\
Surpresa & 4,6607 & 2,94357 \\
& Tristeza & 18,0536 & 12,42639 \\
& & & \\
& Total & 16,5459 & 11,48703 \\
Tarefa 2 & Alegria & 15,3214 & 8,07039 \\
& Medo & 15,1964 & 6,81287 \\
& Neutro & 13,625 & 4,83007 \\
& Nojo & 16,5179 & 9,46955 \\
Raiva & 11,9464 & 5,03233 \\
& Surpresa & 12,1786 & 4,74095 \\
Tristeza & 13,8036 & 5,2481 \\
& & \\
& Total & 14,0842 & 6,6817 \\
\hline
\end{tabular}

Para a realização da análise da trajetória, em busca de tendências que indiquem um padrão de visualização de expressões faciais, três etapas foram conduzidas. Conforme mencionado anteriormente, para este trabalho, uma trajetória foi entendida como uma sequência de fixações em áreas de interesse semanticamente pré-determinadas, de modo a oferecer um entendimento dinâmico da exploração visual de diferentes expressões faciais. Inicialmente, verificou-se a comparação estatística de efeito da emoção e da tarefa na trajetória, através da comparação entre as sequências de AOls ativadas (quantidade de 10 fixações sequenciadas nas diferentes AOls). Nos testes de hipóteses utilizados, não foi possível verificar o efeito da VI emoção. No 
entanto, foi possível verificar que as tarefas 1 e 2 apresentaram efeitos nas trajetórias (Figuras 8 e 9).

\begin{tabular}{|c|c|c|c|c|}
\hline \multicolumn{5}{|c|}{ Resumo de Teste de Hipótese } \\
\hline & Hipótese nula & Teste & Sig. & Decisão \\
\hline 1 & $\begin{array}{l}\text { As categorias de emocoes ocorrem } \\
\text { com iguais probabilidades. }\end{array}$ & $\begin{array}{l}\text { Teste Qui- } \\
\text { Quadrado de } \\
\text { Uma Amostra }\end{array}$ & 1,000 & $\begin{array}{l}\text { Reter a } \\
\text { hipótese } \\
\text { nula. }\end{array}$ \\
\hline 2 & $\begin{array}{l}\text { A distribuição de exp1 é normal } \\
\text { com média } 5,537 \text { e desvio padrão } \\
8,13 \text {. }\end{array}$ & $\begin{array}{l}\text { Um teste } \\
\text { Kolmogorov- } \\
\text { Smirnov de } \\
\text { uma amostra }\end{array}$ &, 000 & $\begin{array}{l}\text { Rejeitar a } \\
\text { hipótese } \\
\text { nula. }\end{array}$ \\
\hline
\end{tabular}

São exibidas significâncias assintóticas. O nivel de significância é ,05.

Figura 8. Teste de Hipóteses para a verificação do efeito das emoções e da distribuição normal dos experimentos.

Resumo de Teste de Hipótese

\begin{tabular}{|clrl|}
\hline \multicolumn{1}{|c}{ Hipótese nula } & \multicolumn{1}{c|}{ Teste } & Sig. & Decisão \\
\hline & $\begin{array}{l}\text { Teste dos } \\
\text { postos } \\
\text { sinalizados de } \\
\text { Wilcoxon de } \\
\text { Amostras } \\
\text { Relacionadas }\end{array}$ & A mediana das diferenças entre \\
exp1 e exp2 é igual a 0. & $\begin{array}{l}\text { Rejeitar a } \\
\text { hipótese } \\
\text { nula. }\end{array}$ \\
& & & \\
\hline
\end{tabular}

São exibidas significâncias assintóticas. O nível de significância é ,05.

Figura 9. Teste de hipóteses para as trajetórias conforme os experimentos.

O efeito da diferenciação da trajetória em relação às duas tarefas é claramente percebido quando distribuímos as frequências das 10 primeiras 
fixações nas AOls para as emoções básicas. Existe uma predominância inicial, independente das emoções, nas AOls referentes ao nariz e à boca (para verificar porcentagens por áreas de interesse, conferir os Anexos de 8 a 14). Tal predominância é maior na tarefa 1, que na tarefa 2, em todas as emoções, conforme apresentado na figura 10.

(A)

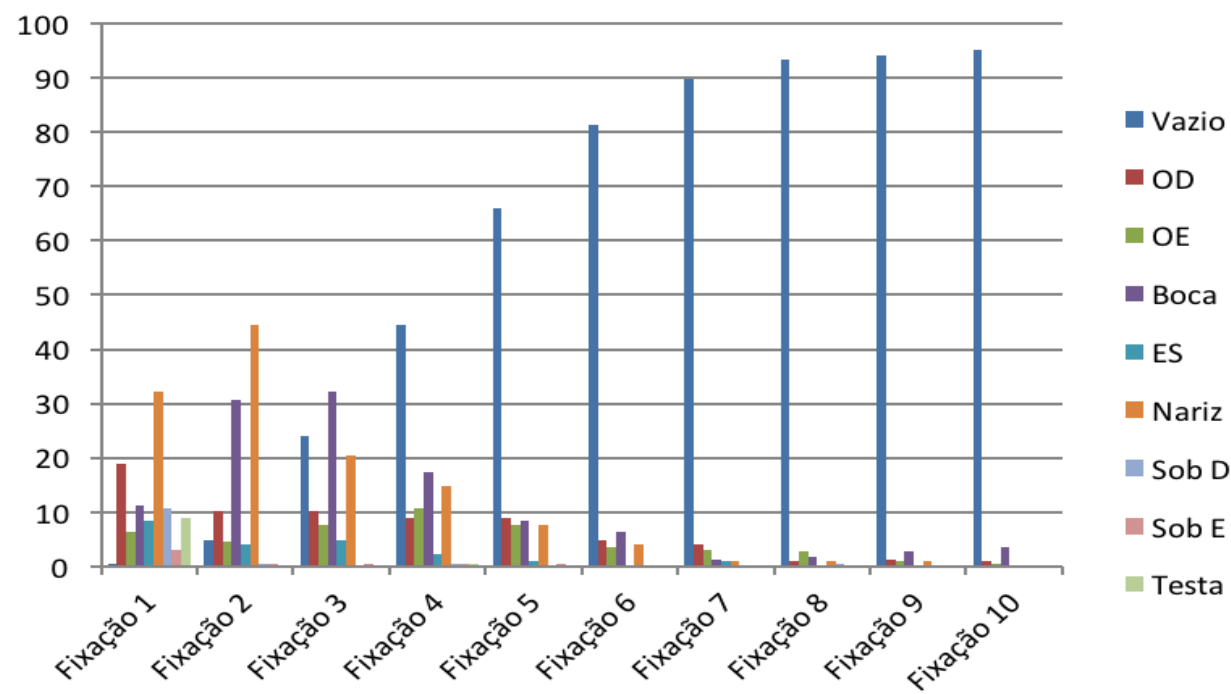

(B)

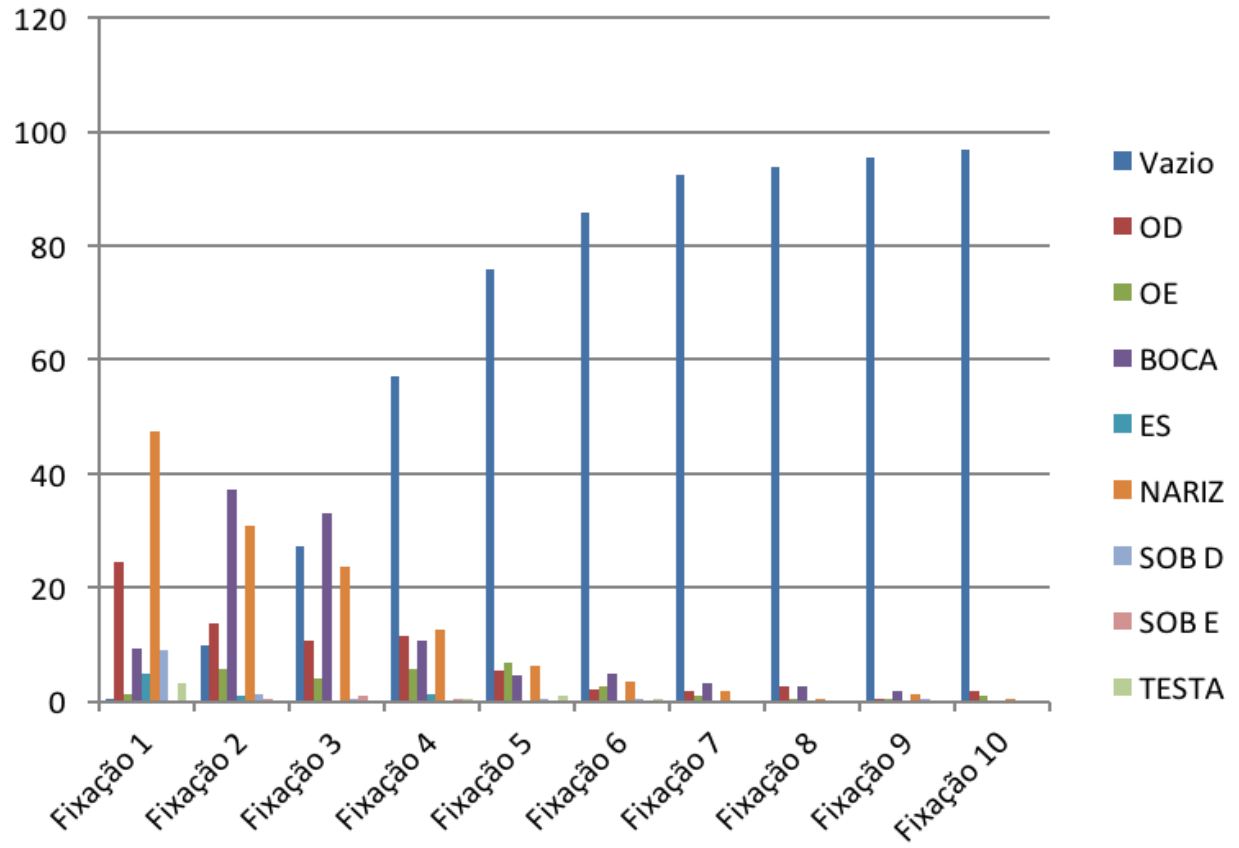

Figura 10. Porcentagem hits nas AOls conforme sequência de fixações para as tarefas 1 (fig A) e 2 (fig. B) - ALEGRIA. 
Ao analisarmos a figura 10(a e b) percebemos que a trajetória para estímulos de alegria é formada inicialmente por fixações no nariz, seguidas de duas fixações na boca. A partir da quarta e quinta fixação nas figuras 10 A e B, respectivamente, a taxa de "vazio", ou seja, ausência de fixações nas AOls semanticamente pré-determinadas aumenta progressivamente, com índices superiores a $50 \%$ das fixações, indicando que mais da metade dos participantes não se fixam mais nestas AOls. Tais efeitos podem ser percebidos nas figuras que retratam as outras emoções, com predominância similar (ver Anexos de 15 a 20).

Assim, as fixações no nariz e na boca, nas duas primeiras fixações, são as de maior expressividade, independente das emoções e da tarefa, seguidos de um pouco de mais de dispersão nas fixações subsequentes, com um aumento na visualização do olho direito e olho esquerdo nas fixações que continuam a ocorrer. Áreas como as das sobrancelhas, entre sobrancelhas e testa são visivelmente ignoradas nas primeiras fixações. Elas são ativadas com fixações, em sua maioria, naqueles indivíduos que continuam a visualização além das quatro ou cinco primeiras fixações.

O efeito da tarefa é visível no tamanho das trajetórias realizadas. A tarefa 1 possui fixações mais longas, já que a quantidade de fixações "vazias", ou seja, a ausência de fixações nas AOls passa a ser maior que a chance $(>50 \%$ ) a partir da quinta fixação, enquanto que na tarefa 2 , isto ocorre a partir da terceira ou quarta fixação. Fica evidenciado, mais uma vez, o efeito bottomup. Por não contar com a facilitação do priming, a tarefa 1 exige uma maior inspeção visual para a tomada de decisão - escolher a qual emoção àquela face se refere. Isto reflete que as fixações na tarefa 1 possivelmente são mais 
curtas individualmente, já que ambas as tarefas possuem tempos muito parecidos de execução (ver Anexos de 8 a 14 para porcentagem de fixações por $\mathrm{AOI})$.

A última etapa da avaliação da trajetória, após a verificação dos efeitos estatísticos e da descrição qualitativa das trajetórias baseada na sequência de fixações em AOls semanticamente relevantes para o reconhecimento de expressões faciais, foi a comparação das médias das distâncias de Levenshtein de cada participante entre as tarefas 1 e 2, já cientes dos efeitos da mesma nas trajetórias. A distância de Levenshtein fornece a quantidade de modificações necessárias para que uma sequência torne-se idêntica a outra.

$\mathrm{Na}$ avaliação das médias das distâncias de Levenshtein para cada participante, pode-se perceber a diferença estatisticamente significativa das similaridades entre as tarefas 1 e 2 , com médias de $3,99(\mathrm{dp}=2,17)$ e $2,89(\mathrm{dp}=1,82)$, respectivamente, sendo $t(55)=5,323$, com $\operatorname{sig}<0,01$, indicando a necessidade de aproximadamente 4 e 3 modificações nas sequencias de trajetórias para que possam se assemelhar. Estas modificações podem ser acrescentando ou diminuindo a extensão da string, acrescentando ou retirando fixações, bem como realizando trocas na sequência de AOls. Há uma maior necessidade de modificações na tarefa 1 , que na tarefa 2 , o que pode ser explicado pelas trajetórias mais longas e dispersas (maior número de fixações). A seguir os índices médios da distância de Levenshtein para os 56 participantes nas duas tarefas (Tabela 9): 
Tabela 9. Índices médios da distância de Levenshtein para as trajetórias.

\begin{tabular}{rrr|rrr} 
Participante & Tarefa 1 & Tarefa 2 & Participante & Tarefa 1 & Tarefa 2 \\
\hline P01 & 4,121693 & 3,743386 & P29 & 1,177249 & 1,248677 \\
P02 & 2,100529 & 1,645503 & P30 & 3,079365 & 2,002646 \\
P03 & 2,769841 & 2,677249 & P31 & 5,915344 & 3,164021 \\
P04 & 3,246032 & 3,079365 & P32 & 9,44709 & 4,121693 \\
P05 & 4,007937 & 5,089947 & P33 & 2,240741 & 1,738095 \\
P06 & 5,164021 & 4,034392 & P34 & 1,375661 & 1,597884 \\
P07 & 5,126984 & 2,843915 & P35 & 2,608466 & 3,214286 \\
P08 & 1,661376 & 1,642857 & P36 & 4,002646 & 2,404762 \\
P09 & 2,357143 & 2,071429 & P37 & 1,957672 & 2,497354 \\
P10 & 1,857143 & 0,941799 & P38 & 3,621693 & 1,537037 \\
P11 & 1,328042 & 1,579365 & P39 & 6,925926 & 5,240741 \\
P12 & 3,465608 & 2,761905 & P40 & 2,193122 & 2,193122 \\
P13 & 2,515873 & 2,566138 & P41 & 9,944444 & 6,727513 \\
P14 & 6,346561 & 3,121693 & P42 & 3,489418 & 2,470899 \\
P15 & 5,626984 & 2,873016 & P43 & 1,865079 & 1,272487 \\
P16 & 2,671958 & 1,494709 & P44 & 2,425926 & 3,994709 \\
P17 & 5,07672 & 2,878307 & P45 & 3,462963 & 2,425926 \\
P18 & 6,074074 & 5,608466 & P46 & 1,351852 & 1,521164 \\
P19 & 4,931217 & 2,767196 & P47 & 2,955026 & 3,494709 \\
P20 & 2,465608 & 2,801587 & P48 & 4,468254 & 3,796296 \\
P21 & 3,835979 & 3,351852 & P49 & 1,566138 & 2,603175 \\
P22 & 6,888889 & 4,952381 & P50 & 5,013228 & 1,640212 \\
P23 & 3,18254 & 2,917989 & P51 & 5,037037 & 2,886243 \\
P24 & 3,399471 & 2,558201 & P52 & 4,851852 & 2,767196 \\
P25 & 5,314815 & 4,047619 & P53 & 4,52381 & 2,494709 \\
P26 & 5,833333 & 5,177249 & P54 & 4,214286 & 2,484127 \\
P27 & 4,746032 & 2,962963 & P55 & 2,338624 & 1,404762 \\
P28 & 11,85979 & 4,367725 & P56 & 3,415344 & 2,346561 \\
\hline & & & & &
\end{tabular}




\section{Discussão}

Os resultados obtidos no presente trabalho estão em conformidade e atingiram os objetivos iniciais de investigar uma tendência e um padrão de trajetória visual, considerando os possíveis efeitos da variação afetiva (diferentes expressões faciais) e dos mecanismos de processamento cognitivo (bottom-up e top-down), através das duas tarefas propostas.

A baixa congruência interna da similaridade das trajetórias para cada participante evidencia que não há uma trajetória idiossincrática no que concerne ao reconhecimento de expressões faciais. No geral, os mecanismos de visualização se concentraram em áreas centrais da face, ocorrendo posteriormente uma dispersão. Este dado contraria resultados propostos em um artigo recente (Kanan et al, 2015), que afirma que o processo de exploração visual segue uma trajetória específica, própria do indivíduo. No entanto, o presente trabalho oferece sustentação a outro dado apresentado neste artigo, no que se refere à influência da tarefa na trajetória visual.

A localização central das primeiras fixações (nariz e boca), independentemente da emoção, sugere a evidência de que a inspeção visual para o julgamento da expressão facial é feita baseada em PCAs (Calder \& Young, 2005), com a junção de componentes relevantes na face, formando um conjunto de características que permitem a identificação da emoção, e não a inspeção pormenorizada da face como um todo. A concentração nestas áreas centrais também se deve, provavelmente, a utilização da visão parafoveal, já que não são necessários tantos detalhes para a identificação de PCAs 
marcantes e evolutivos, como as características principais de expressões faciais.

Calvo, Beltrán e Fernandéz-Martins (2014) afirmam que, considerando a influência da visão periférica no reconhecimento de expressões faciais, o processo de reconhecimento seria muito mais perceptivo e conduzido perceptualmente, levando em conta os componentes de saliência das diferentes expressões, que propriamente um processo de discriminação afetiva. Tais autores fornecem evidências, através de tarefas de mascaramento de estímulos, da influência da visão periférica e parafoveal no reconhecimento de faces, considerando as saliências dos estímulos. Os dados aqui apresentados corroboram estes resultados, visto que a concentração central de fixações iniciais posicionam-se no nariz, permitindo uma identificação de signos rotineiramente associados a diferentes emoções e, consequentemente salientes, como a boca aberta de surpresa, a língua para fora do nojo e o sorriso da alegria. De fato, tem-se muito mais uma questão de saliência e significação semântica, que propriamente de identificação afetiva.

A baixa taxa de fixação em áreas semanticamente reconhecidas como importantes no processo de reconhecimento como os olhos, e áreas associadas às unidades de ação de Paul Ekman, como as sobrancelhas e a região entre sobrancelhas também sugere que o reconhecimento de faces é fortemente dirigido pela visão parafoveal. Outro aspecto de relevância é que boa parte de estudos que apontam os olhos como áreas frequentemente visualizadas, utilizam-se apenas de informações espaciais, em seus métodos de análises, desconsiderando a distribuição temporal das fixações. 
O efeito da tarefa fica bastante evidente quando consideramos a extensão das trajetórias e a distância de Levenshtein. Tais achados permitem, mais uma vez, fornecer subsídios à teoria de Yarbus (1967), que sustenta que a trajetória visual é influenciada pela tarefa, bem como, apresenta mais evidências do priming e no direcionamento do olhar. Integrando as informações acerca do tempo e da taxa de erros, percebe-se que o priming favorece a diminuição do tempo de visualização dos estímulos, no caso da tarefa 2 . No entanto, os estímulos congruentes acabam por dificultar a tarefa, sendo guiado muito mais pelo processo bottom-up. O efeito top-down ocorre muito mais fortemente nos estímulos incongruentes da tarefa 2. Alguns participantes relataram que a "dica" da emoção na tarefa 2 auxiliava na exploração visual mais rápida, mas a tarefa tornava-se mais difícil devido a necessidade de recordar-se do nome da emoção apresentada, do estímulo visualizado, depois comparar as duas informações e assim escolher a melhor resposta. Quando as emoções eram incongruentes, a diferença era evidente e exigia um menor esforço cognitivo.

Em relação a não predominância da visualização da região dos olhos, conforme indicado por estudos anteriores, faz-se a ressalva de que talvez isto se deva a uma questão metodológica. Quando consideramos a duração das fixações e sua distribuição, mas não sua ordem cronológica, como no caso da representação gráfica dos mapas de calor, percebe-se fixações nas áreas dos olhos, nariz e boca. A referência às áreas do nariz e da boca não traduzem a predominância destas na resultante das fixações totais, mas sim, na predominância no início das fixações de uma trajetória. 
A presente pesquisa objetivou identificar padrões de trajetória visual para o reconhecimento de expressões faciais, considerando os efeitos afetivos das diferentes emoções básicas e das tarefas propostas. Uma tendência na exploração visual inicial foi identificada, com predominância de visualização do nariz, boca e olho direito nas primeiras fixações, bem como uma distribuição das AOls acessadas nas fixações subsequentes. Foi possível identificar um tamanho curto de trajetória visual na exploração e reconhecimento de expressões faciais, sendo ainda menor nas tarefas que envolviam componentes de processamento cognitivo primordialmente top-down. $\mathrm{O}$ efeito perceptual e psicofísico foi percebido, traduzido no conceito de saliência visual, na execução das tarefas, dada a centralização das fixações, evidenciando uma possível visualização parafoveal dos estímulos emocionais e uma exploração baseada em análises de componentes principais (PCAs), com foco em regiões de interesse com conteúdo significativo para as tarefas propostas.

A trajetória visual, por ser dinâmica e formada por diferentes dimensões, é uma medida de difícil comparação e análise. Para a utilização da distância de Levenshtein, foi necessário excluir a duração das fixações dos cálculos. De fato, diferentes algoritmos oferecem diferentes análises. E a divergência de resultados entre os pesquisadores, ainda é fruto do desenvolvimento da área.

A magnitude do banco de dados também foi um fator de forte influência na presente tese. Foram 56 participantes avaliados, explorando 56 expressões faciais diferentes, totalizando 3136 trajetórias visuais. Espera-se utilizar futuramente este banco de dados para testes de diferentes algoritmos em 
busca de agrupamentos dinâmicos, que possam sustentar a trajetória visual no processo de reconhecimento de expressões faciais emocionais. 


\section{Referências}

Adolphs, R. (2002). Recognizing Emotion From Facial Expressions:

Psychological and Neurological Mechanisms. Behavioral and Cognitive Neuroscience Reviews, 1(1), 21-62.

Barrett, L. F. (2012). Emotions are real. Emotion (Washington, D.C.), 12(3), 413-29. http://doi.org/10.1037/a0027555

Biehl, M., Matsumoto, D., Ekman, P., Meant, V., Heider, K., Kudoh, T., \& Ton, V. (1997). Matsumoto and Ekman's japanese and caucasia facial expressions of emotion: reliability data and cross-national differences. Journal of Nonverbal Behavior, 21(1), 3-21.

Brosch, T., Pourtois, G., \& Sander, D. (2010). The perception and categorisation of emotional stimuli: A review. Cognition \& Emotion, 24(3), 377-400. http://doi.org/10.1080/02699930902975754

Calder, A. J., Keane, J., Manly, T., Sprengelmeyer, R., Scott, S., Nimmo-Smith, I., \& Young, A. W. (2003). Facial expression recognition across the adult life span. Neuropsychologia, 41(2), 195-202. Retrieved from http://www.ncbi.nlm.nih.gov/pubmed/12459217

Calder, A. J., \& Young, A. W. (2005). Understanding the recognition of facial identity and facial expression. Nature Reviews. Neuroscience, 6(8), 64151. http://doi.org/10.1038/nrn1724

Calder, A. J., Young, A. W., Keane, J., \& Dean, M. (2000). Configural information in facial expression perception. Journal of Experimental Psychology. Human Perception and Performance, 26(2), 527-51. Retrieved from http://www.ncbi.nlm.nih.gov/pubmed/10811161

Clark, U. S., Neargarder, S., \& Cronin-golomb, A. (2010). Visual Exploration of Emotional Facial Expressions in Parkinson's Disease. Neuropsychologia, 48(7), 1901-1913.

http://doi.org/10.1016/j.neuropsychologia.2010.03.006.Visual

Cohn, J. F., Zlochower, a J., Lien, J., \& Kanade, T. (1999). Automated face analysis by feature point tracking has high concurrent validity with manual FACS coding. Psychophysiology, 36(1), 35-43. Retrieved from http://www.ncbi.nlm.nih.gov/pubmed/10098378

Cooke, L. (2005). Eye Tracking: How It Works and How It Relates to Usability. Technical Communication, 52(4), 456-463. 
Cosmides, L., \& Tooby, J. (2013). Evolutionary psychology: new perspectives on cognition and motivation. Annual Review of Psychology, 64, 201-29. http://doi.org/10.1146/annurev.psych.121208.131628

Dael, N., Mortillaro, M., \& Scherer, K. R. (2012). Emotion expression in body action and posture. Emotion (Washington, D.C.), 12(5), 1085-101. http://doi.org/10.1037/a0025737

Darwin, C. (1872/1998). The expression of the emotions in man and animals (3rd ed.). New York: Oxford University Press.

Duchowski, A. T. (2002). A breadth-first survey of eye-tracking applications. Behavior Research Methods, Instruments, \& Computers : A Journal of the Psychonomic Society, Inc, 34(4), 455-70. Retrieved from http://www.ncbi.nlm.nih.gov/pubmed/12564550

Duchowski, A. T. (2007). Eye Tracking Methodology: Theory and Practice (2nd ed.). London: Springer.

Eisenbarth, H., \& Alpers, G. W. (2011). Happy mouth and sad eyes: scanning emotional facial expressions. Emotion (Washington, D.C.), 11(4), 860-5. http://doi.org/10.1037/a0022758

Ekman, P. (1970). Universal Facial Expressions of Emotion. California Mental Health Research Digest, 8(4), 151-158.

Ekman, P. (1972). Universal and Cultural Differences in Facial Expression of Emotion. In J. Cole (Ed.), Nebraska Symposium on Motivation, vol. 19 (pp. 207-282). Nebraska: Lincoln University of Nebraska Press.

Ekman, P. (1992). Are There Basic Emotions? Psychology Review, 99(3), 550553.

Ekman, P. (1994). Strong Evidence for Universals in Facial Expressions: a reply to Russel's mistaken critique. Psychological Bulletin, 115(2), 268-287.

Ekman, P. (1999). Basic Emotions. In T. Dalgleiish \& M. Power (Eds.), Handbook of Cognition and Emotion. Sussex: Wiley \& Sons.

Ekman, P. (2003). Emotions Revealed (1st ed.). New York, New York, USA: Henry Holt and Company.

Ekman, P. (2006). Darwin, Deception, and Facial Expression. Annals of the New York Academy of Sciences, 1000(1), 205-221.

http://doi.org/10.1196/annals.1280.010

Ekman, P., \& Cordaro, D. (2011). What is Meant by Calling Emotions Basic. Emotion Review, 3(4), 364-370. http://doi.org/10.1177/1754073911410740 
Ekman, P., \& Friesen, W. V. (1971). Constants across cultures in the face and emotion. Journal of Personality and Social Psychology, 17(2), 124-9. Retrieved from http://www.ncbi.nlm.nih.gov/pubmed/5542557

Ekman, P., \& Friesen, W. (1969). The repertoire of non verbal behavior: categories, origins, usage, and coding. Semiotica, 1(1), 49-98.

Ekman, P., \& Friesen, W. (1978). Facial Action Coding System: A Technique for the Measurement of Facial Movement. Palo Alto: Consulting Psychologists Press.

Ekman, P., Friesen, W., \& Ellsworth, P. (1982). What emotion categories or dimensions can observers judge from facial behavior? In P. Ekman (Ed.), Emotion in the Human Face (pp. 39-55). New York: Cambridge University Press.

Ekman, P., \& Rosenberg, E. L. (1997). What the face reveals: Basic and applied studies of spontaneous expression using the Facial Action Coding System (FACS). Oxford University Press.

Elfenbein, H. A. (2006). Learning in emotion judgments: Training and the crosscultural understanding of facial expressions. Journal of Nonverbal Behavior, 30(1), 21-36. http://doi.org/10.1007/s10919-005-0002-y

Elfenbein, H. A. (2013). Nonverbal Dialects and Accents in Facial Expressions of Emotion. Emotion Review, 5(1), 90-96.

http://doi.org/10.1177/1754073912451332

Elfenbein, H. A., \& Ambady, N. (2003). Universals and cultural differences in recognizing emotions. Current Directions in Psychological ..., 12(5), 159164. Retrieved from http://cdp.sagepub.com/content/12/5/159.short

Elfenbein, H. A., Beaupré, M., Lévesque, M., \& Hess, U. (2007). Toward a dialect theory: cultural differences in the expression and recognition of posed facial expressions. Emotion (Washington, D.C.), 7(1), 131-46. http://doi.org/10.1037/1528-3542.7.1.131

Elfenbein, H. A., Mandal, M. K., Ambady, N., Harizuka, S., \& Kumar, S. (2002). Cross-cultural patterns in emotion recognition: Highlighting design and analytical techniques. Emotion, 2(1), 75-84. http://doi.org/10.1037//15283542.2.1.75

Fasel, B., \& Luettin, J. (2003). Automatic facial expression analysis: a survey. Pattern Recognition, 36(1), 259-275. http://doi.org/10.1016/S00313203(02)00052-3

Fernandez-Dols, J.-M. (2013). Advances in the Study of Facial Expression: An Introduction to the Special Section. Emotion Review, 5(1), 3-7. http://doi.org/10.1177/1754073912457209 
Gendron, M., Lindquist, K. A., Barsalou, L., \& Barrett, L. F. (2012). Emotion words shape emotion percepts. Emotion (Washington, D.C.), 12(2), 31425. http://doi.org/10.1037/a0026007

Hall, J. K., Hutton, S. B., \& Morgan, M. J. (2010). Sex differences in scanning faces: Does attention to the eyes explain female superiority in facial expression recognition? Cognition \& Emotion, 24(4), 629-637. http://doi.org/10.1080/02699930902906882

Harnad, S. (2005). To Cognize is to Categorize: Cognition is Categorization. In $\mathrm{H}$. Cohen \& C. Lefebvre (Eds.), Handbook of Categorization in Cognitive Sciences (1st ed., pp. 19-43). Oxford: Elsevier Science. http://doi.org/10.1016/B978-008044612-7/50056-1

Hess, U., \& Thibault, P. (2009). Darwin and emotion expression. The American Psychologist, 64(2), 120-8. http://doi.org/10.1037/a0013386

Holmqvist, K., Nyström, M., Andersson, R., Dewhurst, R., Jarodzka, H., \& Van de Weijer, J. (2011). Eye tracking: A comprehensive guide to methods and measures (1st ed.). New York: Oxford University Press.

Horley, K., Williams, L. M., Gonsalvez, C., \& Gordon, E. (2004). Face to face: visual scanpath evidence for abnormal processing of facial expressions in social phobia. Psychiatry Research, 127(1-2), 43-53.

http://doi.org/10.1016/j.psychres.2004.02.016

Izard, C. E. (1994). Innate and Universal Facial Expressions: Evidence from developmental and cross-cultural research. Psychological Bulletin, 115(2), 288-299.

Izard, C. E. (2010). The Many Meanings/Aspects of Emotion: Definitions, Functions, Activation, and Regulation. Emotion Review, 2(4), 363-370. http://doi.org/10.1177/1754073910374661

Jack, R. E., Blais, C., Scheepers, C., Schyns, P. G., \& Caldara, R. (2009). Cultural confusions show that facial expressions are not universal. Current Biology : CB, 19(18), 1543-8. http://doi.org/10.1016/j.cub.2009.07.051

Jack, R. E., Garrod, O. G. B., Yu, H., Caldara, R., \& Schyns, P. G. (2012). Facial expressions of emotion are not culturally universal. Proceedings of the National Academy of Sciences of the United States of America, 109(19), 7241-4. http://doi.org/10.1073/pnas.1200155109

Jessen, S., \& Kotz, S. A. (2011). The temporal dynamics of processing emotions from vocal, facial, and bodily expressions. Neurolmage, 58(2), 665-74. http://doi.org/10.1016/j.neuroimage.2011.06.035

Kagan, J. (2007). What is emotion? History, measures and meanings. New Haven: Yale University Press. 
Kanan, C., Bseiso, D., Ray, N., Hsiao, J., \& Cottrell, G. (2015). Humans have idiosyncratic and task-specific scanpaths for judging faces. Vision Research,108: 67-76. http://dx.doi.org/10.1016/j.visres.2015.01.013.

Karatekin, C. (2007). Eye tracking studies of normative and atypical development. Developmental Review, 27(3), 283-348. http://doi.org/10.1016/j.dr.2007.06.006

Kowler, E. (2011). Eye movements: the past 25 years. Vision Research, 51(13), 1457-83. http://doi.org/10.1016/j.visres.2010.12.014

Krumhuber, E. G., Tamarit, L., Roesch, E. B., \& Scherer, K. R. (2012).

FACSGen 2.0 animation software: generating three-dimensional FACSvalid facial expressions for emotion research. Emotion (Washington, D.C.), 12(2), 351-63. http://doi.org/10.1037/a0026632

Land, M. F. (2006). Eye movements and the control of actions in everyday life. Progress in Retinal and Eye Research, 25(3), 296-324. http://doi.org/10.1016/j.preteyeres.2006.01.002

Ledoux, J. E. (2000). Emotion circuits in the brain. Annual Review of Neuroscience, 23, 155-184.

Lee, K.-Y., Lee, T.-H., Yoon, S.-J., Cho, Y. S., Choi, J.-S., \& Kim, H. T. (2010). Neural correlates of top-down processing in emotion perception: an ERP study of emotional faces in white noise versus noise-alone stimuli. Brain Research, 1337(2006), 56-63. http://doi.org/10.1016/j.brainres.2010.03.094

Levenson, R. W. (2011). Basic Emotion Questions. Emotion Review, 3(4), 379386. http://doi.org/10.1177/1754073911410743

Lewis, M. B., Haviland-Jones, J. M., \& Barrett, L. F. (2008). Handbook of Emotions. Contemporary Sociology (3rd ed., Vol. 24). New York: The Guilford Press.

Lindquist, K. A., Wager, T. D., Kober, H., Bliss-Moreau, E., \& Barrett, L. F. (2012). The brain basis of emotion: a meta-analytic review. The Behavioral and Brain Sciences, 35(3), 121-43. http://doi.org/10.1017/S0140525X11000446

Liversedge, S. P., Gilchrist, I. D., \& Everling, S. (2011). The Oxford handbook of eye movements. Oxford: Oxford University Press.

Ma-Kellams, C., \& Blascovich, J. (2012). Inferring the emotions of friends versus strangers: the role of culture and self-construal. Personality \& Social Psychology Bulletin, 38(7), 933-45. http://doi.org/10.1177/0146167212440291 
Marian, D. E., \& Shimamura, A. P. (2012). Emotions in context: pictorial influences on affective attributions. Emotion (Washington, D.C.), 12(2), 371-5. http://doi.org/10.1037/a0025517

Mathôt, S., Cristino, F., Gilchrist, I.D., \& Theeuwes, J. (2012). A simple way to estimate similarity between pairs of eye movement sequences. Journal of Eye Movement Research 5(1):4, 1-15.

Matsumoto, D. (1989). Cultural influences on the percetion of emorion. Journal of Cross-Cultural Psychology, 20(1):92-105.

Matsumoto, D. (1990). Cultural similarities and differences in display rules. Motivation and Emotion, 14(3), 195-214. http://doi.org/10.1007/BF00995569

Matsumoto, D. (1992). American-Japanese Cultural Differences in the Recognition of Universal Facial Expressions. Journal of Cross-Cultural Psychology, 23(1), 72-84. http://doi.org/10.1177/0022022192231005

Matsumoto, D., \& Hwang, H. S. (2011). Evidence for training the ability to read microexpressions of emotion. Motivation and Emotion, 35(2), 181-191. http://doi.org/10.1007/s11031-011-9212-2

Matsumoto, D., \& Hwang, H. C. (2014). Judgments of subtle facial expressions of emotion. Emotion, 14(2): 349-357. doi: 10.1037/a0035237.

Matsumoto, D., Hwang, H. S., \& Yamada, H. (2010). Cultural Differences in the Relative Contributions of Face and Context to Judgments of Emotions. Journal of Cross-Cultural Psychology, 43(2), 198-218. http://doi.org/10.1177/0022022110387426

Matsumoto, D., \& Willingham, B. (2009). Spontaneous facial expressions of emotion of congenitally and noncongenitally blind individuals. Journal of Personality and Social Psychology, 96(1), 1-10. http://doi.org/10.1037/a0014037

McAndrew, F. T. (1986). A cross-cultural study of recognition thresholds for facial expressions of emotion. Journal of Cross-Cultural Psychology, 17(2), 211-224.

Nelson, N. L., \& Russell, J. A. (2013). Universality Revisited. Emotion Review, 5(1), 8-15. http://doi.org/10.1177/1754073912457227

Noton, D., \& Stark, L. (1971). Scanpaths in saccadic eye movements while viewing and recognizing patterns. Vision Research, 11(9), 929-42.

Retrieved from http://www.ncbi.nlm.nih.gov/pubmed/6487407

Ogrocki, P., Hills, A., \& Strauss, M. (2000). Visual Exploration of Facial Emotion by Healthy Older Adults and Patients with Alzheimer Disease. 
Neuropsychiatry, Neuropsychology, and Behavioral Neurology, 13(4), 271 $-278$.

Olatunji, B. O., Ciesielski, B. G., Armstrong, T., \& Zald, D. H. (2011). Emotional expressions and visual search efficiency: specificity and effects of anxiety symptoms. Emotion (Washington, D.C.), 11(5), 1073-9. http://doi.org/10.1037/a0021785

Ortony, A., Clore, G., Frijda, N., Gray, J., Ellsworth, P., Johnson-laird, P., ... Watts, F. (1990). What's Basic About Basic Emotions? Psychological Review, 97(3), 315-331.

Panksepp, J. (2010). Affective neuroscience of the emotional BrainMind: evolutionary perspectives and implications for understanding depression. Dialogues in Clinical Neuroscience, 12(4), 533-545.

Panksepp, J., \& Watt, D. (2011). What is Basic about Basic Emotions? Lasting Lessons from Affective Neuroscience. Emotion Review, 3(4), 387-396. http://doi.org/10.1177/1754073911410741

Paulmann, S., \& Pell, M. D. (2011). Is there an advantage for recognizing multimodal emotional stimuli? Motivation and Emotion, 35(2), 192-201. http://doi.org/10.1007/s11031-011-9206-0

Pelphrey, K., Sasson, N. J., Reznick, J. S., Paul, G., Goldman, B. D., \& Piven, J. (2002). Visual scanning of faces in autism. Journal of Autism and Developmental Disorders, 32(4), 249-61. Retrieved from http://www.ncbi.nlm.nih.gov/pubmed/12199131

Pessoa, L. (2008). On the relationship between emotion and cognition. Nature Reviews. Neuroscience, 9(2), 148-58. http://doi.org/10.1038/nrn2317

Rayner, K. (1998). Eye movements in reading and information processing: 20 years of research. Psychological Bulletin, 124(3), 372-422. Retrieved from http://www.ncbi.nlm.nih.gov/pubmed/9849112

Regenbogen, C., Schneider, D. a, Gur, R. E., Schneider, F., Habel, U., \& Kellermann, T. (2012). Multimodal human communication--targeting facial expressions, speech content and prosody. Neurolmage, 60(4), 2346-56. http://doi.org/10.1016/j.neuroimage.2012.02.043

Richardson, D. C., \& Spivey, M. J. (2004). Eye-Tracking: Characteristics and Methods. In Encyclopedia of Biomaterials and Biomedical Engineering (pp. 568-572). http://doi.org/10.1081/E-EBBE-120013920

Russell, J. A. (1994). Is there universal recognition of emotion from facial expression? A review of the cross-cultural studies. Psychological Bulletin, 115(1), 102-41. Retrieved from http://www.ncbi.nlm.nih.gov/pubmed/8202574 
Rutherford, M. D., \& Towns, A. M. (2008). Scan path differences and similarities during emotion perception in those with and without autism spectrum disorders. Journal of Autism and Developmental Disorders, 38(7), 137181. http://doi.org/10.1007/s10803-007-0525-7

Sassi, F., Campoy, G., Castillo, A., Inuggi, A., \& Fuentes, L. J. (2014). Task difficulty and response complexity modulate affective priming by emotional facial expressions. Quaterly Journal of Experimental Psychology, 67(5): 861-871, doi: 10.1080/17470218.2013.836233

Sauter, D. a, Eisner, F., Ekman, P., \& Scott, S. K. (2010). Cross-cultural recognition of basic emotions through nonverbal emotional vocalizations. Proceedings of the National Academy of Sciences of the United States of America, 107(6), 2408-12. http://doi.org/10.1073/pnas.0908239106

Scherer, K. R. (2000). Psychological Models of Emotion. In J. Borod (Ed.), The Neuropsychology of Emotion (1st ed., pp. 137 -162). New York: Oxford University Press.

Smith, E., \& Kosslyn, S. (2007). Perception. In Cognitive Psychology: Mind and Brain (1st ed., pp. 49-102). New Jersey: Pearson Prentice Hall.

Tatler, B. W., Wade, N. J., Kwan, H., Findlay, J. M., \& Velichkovsky, B. M. (2010). Yarbus, eye movements, and vision. I-Perception, 1(1), 7-27. http://doi.org/10.1068/i0382

Tobbi, T. (2011). Tobii T60 \& T120 Eye Tracker: User Manual. Tobii Technology AB. Retrieved from http://www.tobii.com/Global/Analysis/Downloads/User_Manuals_and_Guid es/Tobii_T60_T120_EyeTracker_UserManual.pdf

Toh, W. L., Rossell, S. L., \& Castle, D. J. (2011). Current visual scanpath research: a review of investigations into the psychotic, anxiety, and mood disorders. Comprehensive Psychiatry, 52(6), 567-79. http://doi.org/10.1016/j.comppsych.2010.12.005

Tottenham, N., Tanaka, J. W., Leon, A. C., McCarry, T., Nurse, M., Hare, T. a, ... Nelson, C. (2009). The NimStim set of facial expressions: judgments from untrained research participants. Psychiatry Research, 168(3), 242-9. http://doi.org/10.1016/j.psychres.2008.05.006

Tracy, J. L., \& Randles, D. (2011). Four Models of Basic Emotions: A Review of Ekman and Cordaro, Izard, Levenson, and Panksepp and Watt. Emotion Review, 3(4), 397-405. http://doi.org/10.1177/1754073911410747

Tracy, J. L., Robins, R. W., \& Schriber, R. a. (2009). Development of a FACSverified set of basic and self-conscious emotion expressions. Emotion (Washington, D.C.), 9(4), 554-9. http://doi.org/10.1037/a0015766 
Vassallo, S., Cooper, S. L., \& Douglas, J. M. (2009). Visual scanning in the recognition of facial affect : Is there an observer sex difference? Journal of Vision, 9(3)(11), 1-10. http://doi.org/10.1167/9.3.11. Introduction

Vick, S.-J., Waller, B. M., Parr, L. A., Smith Pasqualini, M. C., \& Bard, K. A. (2007). A Cross-species Comparison of Facial Morphology and Movement in Humans and Chimpanzees Using the Facial Action Coding System (FACS). Journal of Nonverbal Behavior, 31(1), 1-20. http://doi.org/10.1007/s10919-006-0017-z

Wallbot, H. G., \& Ricci-Bitti, P. (1993). Decoder' processing of emotional facial expression - a top-down or bottom-up mechanism? European Journal of Social Psychology, 23, 427-443.

Whalen, P. J., Raila, H., Bennett, R., Mattek, A., Brown, A., Taylor, J., ... Palmer, A. (2013). Neuroscience and facial expressions of emotion: The role of amygdala-prefrontal interactions. Emotion Review, 5(1), 78-83. http://doi.org/10.1177/1754073912457231

Williams, L. M., Loughland, C. M., Gordon, E., \& Davidson, D. (1999). Visual scanpaths in schizophrenia: is there a deficit in face recognition? Schizophrenia Research, 40(3), 189-99. Retrieved from http://www.ncbi.nlm.nih.gov/pubmed/10638857

Wilson, C. E., Palermo, R., \& Brock, J. (2012). Visual scan paths and recognition of facial identity in autism spectrum disorder and typical development. PloS One, 7(5), e37681. http://doi.org/10.1371/journal.pone.0037681

Yang, G.-Z., Dempere-Marco, L., Hu, X.-P., \& Rowe, A. (2002). Visual search: psychophysical models and practical applications. Image and Vision Computing, 20(4), 291-305. http://doi.org/10.1016/S0262-8856(02)00022-7

Yarbus, A. L. (1967). Eye Movements and Vision. New York: Plenum Press.

Young, L. R., \& Sheena, D. (1975). Survey of eye movement recording methods. Behavior Research Methods \& Instrumentation, 7(5), 397-429. 
Anexos 


\section{Anexo 1 - Questionário / Roteiro de Entrevista Estruturada}

A seguir, peço que você responda estas perguntas com sinceridade. Não se preocupe, pois sua identidade e respostas não serão divulgados. As informações aqui obtidas serão utilizadas apenas para os fins desta pesquisa e não serão compartilhadas com outros pesquisadores.

Nome:

Sexo:

Idade:

Escolaridade:

Instituição afiliada:

Email para contato:

Lateralidade:

1. Você dormiu bem na noite anterior? ( ) Sim ( ) Não

2. Você possui histórico de alguma doença psiquiátrica? ( ) Sim ( ) Não Se sim, qual(is)?

( ) Depressão

( ) Transtorno Bipolar

( ) Episódio Maníaco

( ) Episódio Hipomaníaco

( ) Episódio Depressivo

( ) Fobia

3. Você já apresentou:

Crise convulsiva ( ) Sim ( ) Não

Com que frequência?

Há quanto tempo?

Epilepsia ( ) Sim ( ) Não

Crises com que frequência?

4. Você apresenta ou apresentou alguma outra condição neurológica?

( ) $\operatorname{Sim}($ ) Não.

Se sim, qual?
( ) Transtorno do Stress Pós-

Traumático

( ) Transtorno de Ansiedade

Generalizada

( ) Esquizofrenia

( ) Outro(a). Qual? 
5. Você faz uso de alguma medicação psicotrópica ou neurolépticos?

( ) $\operatorname{Sim}($ ) Não

Se sim, qual(is)?

6. Você possui alguma dificuldade visual? ( ) Sim ( ) Não

( ) Miopia Grau: OD__ OE

( ) Astigmatismo Grau: OD__ OE

( ) Hipermetropia Grau: OD__ OE

( ) Catarata ( ) Estrabismo

( ) Daltonismo ( ) Glaucoma

( ) Outra(s)

7. Você usa óculos ou lentes de contato adequados para a sua dificuldade visual? ( ) Sim ( ) Não

8. Você possui dificuldade em reconhecer e identificar uma face ou de reconhecer objetos?

( ) Sim ( ) Não

9. Você consegue identificar emoções nos outros através das expressões faciais que eles produzem?

( ) $\operatorname{Sim}($ ) Não

10. Você já visualizou anteriormente alguma fotografia da bateria NimStim?

( ) Sim ( ) Não

11. Você possui algum treinamento prévio em reconhecimento de expressões faciais?

( ) $\operatorname{Sim}($ ) Não

12. Como você classificaria o seu estado de humor nesse exato momento (Escolha no máximo três opções):

( ) Feliz

( ) Calmo(a)

( ) Triste

( ) Angustiado(a) / Preocupado(a)
( ) Irritado(a) / Impaciente

( ) Ansioso(a)

( ) Indiferente

( ) Outro 
Declaro para os devidos fins que as informações acima são verídicas.

Fortaleza, de de 201

Assinatura 


\section{Anexo 2 - Termo de Consentimento Livre e Esclarecido - Experimento}

Ao participante da pesquisa

Prezado (a)

Somos pesquisadores da Universidade de Brasília (UnB), da área de Psicologia. Você está sendo convidado(a) a participar de uma pesquisa que investigará o reconhecimento das expressões emocionais.

Compreender este fenômeno é importante, pois essa pesquisa pode contribuir, no futuro, para um entendimento mais ampliado do processo de reconhecimento de emoções através das expressões faciais.

O objetivo é investigar como imagens de diferentes expressões faciais são classificadas por nossa população e de que maneira nós visualizamos as diferentes expressões emocionais faciais básicas.

Nossa pesquisa está dividida em duas ações:

1) Leitura conjunta e assinatura deste Termo de Consentimento

2) Reconhecimento de expressões faciais em um computador apresentadas individualmente e medição da posição do seu olhar com o auxílio de um equipamento rastreador do olhar.

O procedimento deve demorar, em média, 20 minutos. 0 procedimento poderá causar um pouco de cansaço, no momento, mas não será prejudicial ao seu organismo. Todas as informações relacionadas à sua participação serão mantidas em sigilo. Seus dados pessoais não serão divulgados em hipótese alguma. Esses dados serão utilizados apenas para os fins desta pesquisa, na Universidade de Brasília, não sendo utilizados novamente em pesquisas futuras. Depois de encerrada esta etapa da pesquisa, você receberá os resultados de sua participação. Após a finalização completa da pesquisa, você poderá ter acesso ao trabalho, caso tenha interesse. 
Não há despesas pessoais para o participante em qualquer fase do estudo. Também não há compensação financeira relacionada à sua participação. Se existir qualquer despesa adicional, ela será contemplada pelo orçamento da pesquisa.

Lembramos que a participação neste estudo é voluntária e que a qualquer momento é possível desistir por qualquer motivo, sem nenhum tipo de prejuízo para você. Caso haja alguma dúvida, a pesquisadora responsável pode ser contatada a partir do telefone e do email que constam ao final deste documento.

Caso você se sinta suficientemente informado sobre este estudo e concorde em participar desta pesquisa, solicitamos que assine no espaço abaixo.

Desde já, agradecemos por sua confiança e colaboração.

Cordialmente,

Hélida Arrais Costa Telefone: (85) 96349111

Email: helida@unb.br

Assinatura do participante:

Data:

Telefone:

Email:

Comitê de Ética em Pesquisa - COMEPE / UFC: comepe@ufc.br 
Anexo 3 - Transcrição das instruções fornecidas para o participante ao início da Tarefa 1.

A seguinte instrução foi fornecida na tela do computador:

\section{Instrução 1:}

"A seguir, você verá uma sequência de fotografias de pessoas. Elas aparentam alguma emoção. Peço que observe atentamente cada uma destas figuras e identifique QUAL emoção a pessoa está expressando, o mais rapidamente possível. Assim que você reconhecer a emoção, peço que clique uma vez no mouse, sem desviar o olhar da tela, e aguarde a tela seguinte para responder, clicando na resposta pretendida. Após sua resposta, outra figura será apresentada, dando continuidade ao experimento. ATENÇÃO! Evite desviar o olhar da tela".

\section{Instrução 2:}

"Inicialmente, você realizará duas tentativas, para conhecer a tarefa."

(Seguiram-se os dois estímulos para as tentativas)

\section{Instrução 3:}

"Vamos iniciar o experimento?

Lembre-se de clicar no mouse assim que identificar a emoção." 
Anexo 4 - Transcrição das instruções fornecidas para o participante ao início da Tarefa 2.

As seguintes instruções foram fornecidas em tela, no início do experimento:

\section{Instrução 1}

"Nesta tarefa, você também visualizará diferentes expressões faciais, uma de cada vez. Inicialmente, você visualizará o nome de uma emoção. Você deverá clicar com o mouse ao finalizar a leitura. Em seguida, você visualizará uma expressão facial, a qual você deverá observar o mais rapidamente possível, tentando identificar se a emoção apresentada na figura corresponde ou não ao nome da emoção apresentada anteriormente. Você deverá clicar no mouse assim que souber responder e escolher SIM ou NÃO".

\section{Instrução 2}

"Inicialmente, você realizará duas tentativas, para conhecer a tarefa."

(Seguiram-se os dois estímulos para as tentativas)

\section{Instrução 3}

"Agora, vamos começar o experimento." 


\section{Anexo 5 - Script em VBA-Excel, para extração das trajetórias dos participantes. $^{5}$}

Sub excluirCelulasVazias()

Dim vLin As Long

Dim vCol As Long

Dim lastRow, lastCol As Long

Dim vLinFinal As Long

$\mathrm{vCol}=4$

vLinFinal $=6879$

' lastRow = Cells(Cells.Rows.Count, "A").End(xIUp).Row

' lastCol = Cells(1, Cells.Columns.Count).End(x|ToLeft).Column

' MsgBox "Num. Linhas = " \& lastRow \& " Num.Col = " \& lastCol

For vLin $=3589$ To vLinFinal Step 1

vNulo $=$ True

Do While vNulo $=$ True

' se a célula for vazia

If Len(Cells(vLin, vCol).Value) $=0$ Then

Cells(vLin, vCol).Delete xIToLeft

' --- MsgBox " Lin = " \& vLin \& "Col= " \& vCol \& " Excluída"

Else

vNulo $=$ False

End If

Loop

' próxima linha

Next vLin

MsgBox "Operação Concluída"

End Sub

${ }^{5}$ Autoria de José Sérgio F. da Costa. Fortaleza, 2015. 
Vlin $=2$

Do While Vlin $<6880$

wParticip $=$ Cells $($ Vlin, "A").Value

wEstim = Cells(Vlin, "B").Value

wLin1Grupo $=$ Vlin

' ---- MsgBox "Próximo Par: " \& wParticip \& " " \& wEstim

Do While Cells(Vlin, "A").Value = wParticip And Cells(Vlin, "B").Value = wEstim

For $\mathrm{i}=4$ To 11 Step 1

If Cells(Vlin, i).Value $=1$ Then

' ---- MsgBox " Encontrou valor"

Cells(wLin1Grupo, "M").Value = Cells(wLin1Grupo, "M").Value \& $\operatorname{Mid}($ VLetras, i, 1)

' ---- MsgBox " Marcadores: " \& Cells(wLin1Grupo, "M").Value

Exit For

End If

Next i

Vlin $=$ Vlin +1

Loop ' -- próx. par participante x estímulo

Loop

MsgBox "Operação Encerrada"

End

End Sub 
Anexo 6 - Script adaptado para VBA-Excel, para comparação das trajetórias visuais. ${ }^{6}$

\section{Option Explicit}

\section{Sub CalcSimilar()}

Dim s1 As String, s2 As String, Pi, pNext, vCol, linMax As Long

'---- Indicar a letra da coluna onde estão as strings a serem comparadas linMax = 29 '--- última linha da planilha dos dados a comparar For $\mathrm{Pi}=2$ To linMax Step 1 ' ---- percorre todas as linhas $\mathrm{vCol}=5^{\prime}$---- coluna inicial dos valores Levenshtein $\mathrm{s} 1=$ Cells(Pi, "D").Value For pNext $=\mathrm{Pi}+1$ To linMax Step 1 ' --- percorre todas as linhas seguintes s2 = Cells (pNext, "D").Value Cells $(\mathrm{Pi}, \mathrm{vCol}) \cdot$ Value $=$ Levenshtein $(\mathrm{s} 1, \mathrm{~s} 2)$ $\mathrm{vCol}=\mathrm{vCol}+1$

Next

Next

MsgBox "Operação concluída"

End Sub

'Option Base 0 assumed

'POB: fn with byte array is 17 times faster

Function Levenshtein(ByVal string1 As String, ByVal string2 As String) As Long

Dim i As Long, j As Long, bs1() As Byte, bs2() As Byte

Dim string1_length As Long

Dim string2_length As Long

\footnotetext{
${ }^{6}$ Adaptado e implementado por José Sérgio F. da Costa. Fortaleza, 2015.
} 
Dim distance() As Long

Dim min1 As Long, min2 As Long, min3 As Long

string1_length $=$ Len(string1)

string2_length $=$ Len(string2)

ReDim distance(string1_length, string2_length)

bs1 $=$ string 1

bs2 $=$ string2

For $\mathrm{i}=0$ To string1_length

distance $(i, 0)=i$

Next

For $\mathrm{j}=0$ To string2_length

distance $(0, \mathrm{j})=\mathrm{j}$

Next

For $\mathrm{i}=1$ To string1_length

For $\mathrm{j}=1$ To string2_length

'slow way: If Mid $\$$ (string1, i, 1$)=\operatorname{Mid} \$($ string2, j, 1 ) Then

If bs $1\left((i-1){ }^{*} 2\right)=b s 2((j-1) * 2)$ Then $\quad * 2$ because Unicode every 2 nd byte is 0

distance $(\mathrm{i}, \mathrm{j})=\operatorname{distance}(\mathrm{i}-1, \mathrm{j}-1)$

Else

'distance $(\mathrm{i}, \mathrm{j})=$ Application.WorksheetFunction.Min

(distance $(i-1, j)+1$,

distance $(\mathrm{i}, \mathrm{j}-1)+1$,

distance $(i-1, j-1)+1)$

' spell it out, 50 times faster than worksheetfunction.min

$\min 1=\operatorname{distance}(i-1, j)+1$

$\min 2=\operatorname{distance}(\mathrm{i}, \mathrm{j}-1)+1$

$\min 3=\operatorname{distance}(\mathrm{i}-1, \mathrm{j}-1)+1$

If $\min 1<=\min 2$ And $\min 1<=\min 3$ Then

distance $(\mathrm{i}, \mathrm{j})=\min 1$ 
Elself $\min 2<=\min 1$ And $\min 2<=\min 3$ Then distance $(\mathrm{i}, \mathrm{j})=\min 2$

Else

distance $(\mathrm{i}, \mathrm{j})=\min 3$

End If

End If

Next

Next

Levenshtein = distance(string1_length, string2_length)

End Function 
Anexo 7 - Comparação de similaridade das trajetórias de um participante (Exemplificação)

Anexo 7.1. Comparação de similaridade entre as sequências da Tarefa 1 (participante X - exemplificação)

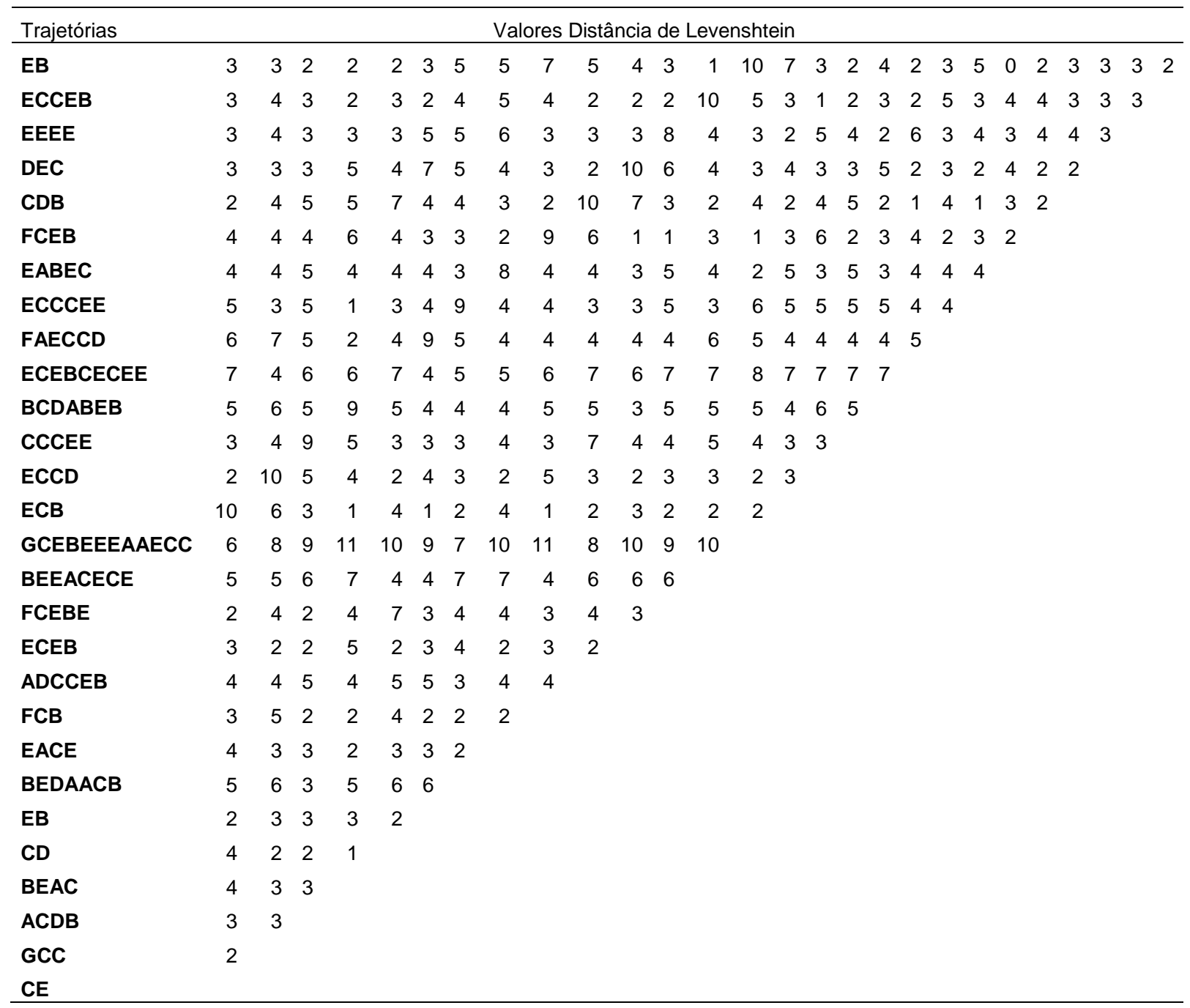

Nota. Os valores das identidades (ex: comparação ECB-ECB), que deveriam iniciar cada linha, foram omitidos. Para visualização, considerar que os valores de cada linha correspondem as comparações do string com seus sucessores. Quanto menor o valor, maior a semelhança entre as trajetórias. Legenda

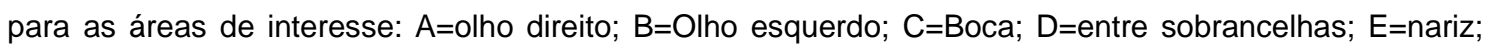
$F=$ sobrancelha direita; $G=$ sobrancelha esquerda; $H=$ Testa. 
Anexo 7.2. Comparação de similaridade entre as sequências da Tarefa 2 (participante $X$ - exemplificação)

\begin{tabular}{|c|c|c|c|c|c|c|c|c|c|c|c|c|c|c|c|c|c|c|c|c|c|c|c|c|c|c|c|}
\hline \multirow{2}{*}{$\begin{array}{l}\text { Trajetórias } \\
\text { ECED }\end{array}$} & \multicolumn{27}{|c|}{ Valores da Distância de Similaridade } \\
\hline & 3 & 3 & 4 & 1 & 5 & 2 & 3 & 3 & 3 & 2 & 2 & 4 & 2 & 8 & 4 & 3 & 5 & 2 & 2 & 2 & 5 & 2 & 3 & 2 & 3 & 4 & 3 \\
\hline ACA & 3 & 4 & 3 & 5 & 3 & 2 & 2 & 3 & 2 & 2 & 4 & 3 & 8 & 5 & 3 & 6 & 4 & 2 & 3 & 6 & 3 & 2 & 3 & 3 & 5 & 3 & \\
\hline FECB & 3 & 2 & 7 & 3 & 2 & 2 & 2 & 3 & 2 & 3 & 3 & 8 & 4 & 2 & 6 & 3 & 3 & 1 & 5 & 3 & 4 & 3 & 3 & 5 & 2 & & \\
\hline EAEECB & 3 & 6 & 3 & 2 & 4 & 4 & 5 & 4 & 4 & 3 & 7 & 4 & 3 & 5 & 4 & 4 & 4 & 4 & 4 & 6 & 4 & 4 & 4 & 4 & & & \\
\hline ECEB & 5 & 1 & 2 & 3 & 2 & 2 & 2 & 4 & 1 & 8 & 4 & 2 & 4 & 2 & 2 & 3 & 4 & 2 & 3 & 2 & 2 & 3 & 2 & & & & \\
\hline EABCAAEA & 5 & 5 & 6 & 6 & 6 & 6 & 5 & 5 & 3 & 5 & 6 & 5 & 6 & 5 & 7 & 7 & 5 & 6 & 5 & 5 & 5 & 6 & & & & & \\
\hline ECEAB & 3 & 3 & 3 & 3 & 3 & 3 & 0 & 7 & 4 & 1 & 3 & 2 & 2 & 4 & 3 & 3 & 3 & 3 & 2 & 4 & 3 & & & & & & \\
\hline EACB & 3 & 2 & 3 & 2 & 3 & 3 & 7 & 4 & 2 & 5 & 2 & 2 & 3 & 5 & 2 & 4 & 2 & 3 & 3 & 2 & & & & & & & \\
\hline DECA & 3 & 3 & 2 & 4 & 3 & 8 & 4 & 3 & 6 & 4 & 2 & 2 & 4 & 3 & 3 & 3 & 3 & 5 & 3 & & & & & & & & \\
\hline EDB & 3 & 2 & 3 & 3 & 9 & 4 & 2 & 6 & 2 & 3 & 3 & 5 & 3 & 4 & 3 & 3 & 5 & 1 & & & & & & & & & \\
\hline CE & 2 & 4 & 3 & 9 & 4 & 3 & 6 & 4 & 3 & 3 & 6 & 2 & 3 & 2 & 4 & 5 & 2 & & & & & & & & & & \\
\hline EC & 3 & 3 & 9 & 4 & 3 & 6 & 3 & 2 & 2 & 6 & 2 & 3 & 2 & 3 & 5 & 1 & & & & & & & & & & & \\
\hline BEABC & 3 & 7 & 3 & 2 & 4 & 5 & 4 & 4 & 5 & 4 & 4 & 4 & 2 & 4 & 3 & & & & & & & & & & & & \\
\hline ECEAB & 7 & 4 & 1 & 3 & 2 & 2 & 4 & 3 & 3 & 3 & 3 & 2 & 4 & 3 & & & & & & & & & & & & & \\
\hline EEABBCAABEA & 5 & 7 & 6 & 8 & 8 & 9 & 9 & 8 & 9 & 8 & 7 & 7 & 9 & & & & & & & & & & & & & & \\
\hline EEBBCE & 3 & 5 & 5 & 4 & 4 & 6 & 3 & 6 & 3 & 3 & 5 & 4 & & & & & & & & & & & & & & & \\
\hline EEAB & 4 & 3 & 3 & 3 & 3 & 3 & 3 & 3 & 2 & 4 & 2 & & & & & & & & & & & & & & & & \\
\hline ECCEABEC & 4 & 4 & 7 & 6 & 4 & 6 & 4 & 3 & 3 & 6 & & & & & & & & & & & & & & & & & \\
\hline ECCDB & 2 & 3 & 5 & 2 & 4 & 2 & 3 & 3 & 3 & & & & & & & & & & & & & & & & & & \\
\hline ECCA & 3 & 5 & 1 & 3 & 1 & 3 & 4 & 3 & & & & & & & & & & & & & & & & & & & \\
\hline FECD & 6 & 3 & 4 & 3 & 4 & 6 & 3 & & & & & & & & & & & & & & & & & & & & \\
\hline HDEEEAB & 6 & 6 & 6 & 5 & 6 & 5 & & & & & & & & & & & & & & & & & & & & & \\
\hline ECCE & 3 & 0 & 3 & 3 & 3 & & & & & & & & & & & & & & & & & & & & & & \\
\hline GCAG & 3 & 3 & 5 & 4 & & & & & & & & & & & & & & & & & & & & & & & \\
\hline ECCE & 3 & 3 & 3 & & & & & & & & & & & & & & & & & & & & & & & & \\
\hline ECABC & 2 & 5 & & & & & & & & & & & & & & & & & & & & & & & & & \\
\hline ЕСАСЕВС & & & & & & & & & & & & & & & & & & & & & & & & & & & \\
\hline
\end{tabular}

Nota. Os valores das identidades, que deveriam iniciar cada linha, foram omitidos. Para visualização, considerar que os valores de cada linha correspondem as comparações do string com seus sucessores. Quanto menor o valor, maior a semelhança entre as trajetórias. Legenda para as áreas de interesse:

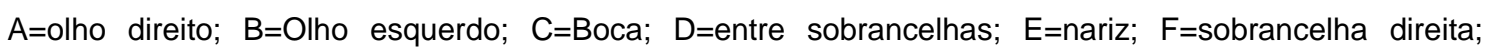
$\mathrm{G}=$ sobrancelha esquerda; $\mathrm{H}=$ Testa. 
Anexos 8 - Tabelas de visualização da porcentagem de fixações nas AOI "Vazio" por emoção

\section{Anexo 8.1. Tarefa 1}

\begin{tabular}{lrrrrrrr} 
& Alegria & Medo & Neutro & Nojo & Raiva & Surpresa & Tristeza \\
\hline Fixação 1 & 0,4 & 0,4 & 0 & 1,3 & 0,9 & 0 & 1,8 \\
Fixação 2 & 4,9 & 7,1 & 5,4 & 10,7 & 6,7 & 14,3 & 6,7 \\
Fixação 3 & 24,1 & 20,1 & 21,4 & 28,1 & 23,2 & 30,4 & 23,2 \\
Fixação 4 & 44,6 & 35,3 & 41,5 & 48,2 & 42 & 48,2 & 42 \\
Fixação 5 & 66,1 & 50,4 & 58 & 67,9 & 57,6 & 63,4 & 56,7 \\
Fixação 6 & 81,3 & 62,1 & 70,5 & 79,5 & 71 & 77,7 & 71 \\
Fixação 7 & 89,7 & 72,3 & 77,2 & 83 & 78,1 & 83,5 & 79,9 \\
Fixação 8 & 93,3 & 77,7 & 85,3 & 89,3 & 86,2 & 89,3 & 84,8 \\
Fixação 9 & 94,2 & 82,1 & 89,7 & 91,1 & 89,7 & 90,2 & 87,5 \\
Fixação & & & & & & & \\
10 & 95,1 & 85,7 & 91,1 & 93,3 & 92,9 & 93,3 & 90,2 \\
\hline
\end{tabular}

\section{Anexo 8.2.Tarefa 2}

\begin{tabular}{rrrrrrrr} 
& Alegria & Medo & Neutro & Nojo & Raiva & Surpresa & Tristeza \\
\hline Fixação 1 & 0,4 & 1,3 & 1,7 & 0,9 & 0,9 & 3,1 & 0,9 \\
Fixação 2 & 9,8 & 9,4 & 13,8 & 8,5 & 8 & 13,4 & 11,6 \\
Fixação 3 & 27,2 & 27,7 & 40,6 & 31,7 & 36,2 & 44,2 & 31,3 \\
Fixação 4 & 57,1 & 55,4 & 75 & 61,2 & 60,7 & 68,8 & 59,4 \\
Fixação 5 & 75,9 & 73,2 & 89,3 & 79 & 79 & 86,6 & 75,4 \\
Fixação 6 & 85,7 & 81,7 & 94,2 & 89,3 & 87,9 & 94,2 & 83,9 \\
Fixação 7 & 92,4 & 87,1 & 97,3 & 94,2 & 95,1 & 96,4 & 89,3 \\
Fixação 8 & 93,8 & 90,6 & 97,8 & 96,9 & 96,9 & 97,8 & 91,5 \\
Fixação 9 & 95,5 & 95,1 & 98,2 & 97,8 & 98,7 & 98,2 & 94,6 \\
Fixação & & & & & & & \\
10 & 96,9 & 96 & 99,6 & 98,7 & 100 & 98,7 & 95,5 \\
\hline
\end{tabular}


Anexos 9 - Tabelas de porcentagem de fixações nas AOl "Nariz" para cada emoção.

\section{Anexo 9.1. Tarefa 1}

\begin{tabular}{rrrrrrrr} 
& Alegria & Medo & Neutro & Nojo & Raiva & Surpresa & Tristeza \\
\hline Fixação 1 & 32,1 & 50,9 & 46,4 & 22,3 & 24,6 & 36,6 & 33,5 \\
Fixação 2 & 44,6 & 41,5 & 46 & 21,9 & 42,4 & 35,7 & 42,9 \\
Fixação 3 & 20,5 & 28,1 & 25,4 & 10,7 & 16,1 & 16,1 & 26,3 \\
Fixação 4 & 14,7 & 22,3 & 18,3 & 7,1 & 15,2 & 15,2 & 14,3 \\
Fixação 5 & 7,6 & 13,8 & 11,6 & 4 & 12,1 & 12,1 & 8 \\
Fixação 6 & 4 & 10,7 & 8,5 & 3,6 & 6,3 & 5,8 & 6,7 \\
Fixação 7 & 0,9 & 8,9 & 5,4 & 2,7 & 4,5 & 4 & 3,6 \\
Fixação 8 & 0,9 & 6,3 & 4 & 2,2 & 4 & 3,1 & 3,1 \\
Fixação 9 & 0,9 & 4 & 0,9 & 1,8 & 3,1 & 0,9 & 1,3 \\
Fixação & & & & & & & \\
10 & 0 & 1,8 & 1,8 & 0,4 & 1,8 & 0,9 & 1,8 \\
\hline
\end{tabular}

\section{Anexo 9.2. Tarefa 2}

\begin{tabular}{lrrrrrrr} 
& Alegria & Medo & Neutro & Nojo & Raiva & Surpresa & Tristeza \\
\hline Fixação 1 & 47,3 & 47,3 & 52,2 & 57,6 & 25 & 58,5 & 35,3 \\
Fixação 2 & 30,8 & 33,9 & 42,4 & 39,7 & 38,4 & 32,1 & 31,3 \\
Fixação 3 & 23,7 & 23,7 & 19,2 & 25 & 16,1 & 18,3 & 23,2 \\
Fixação 4 & 12,5 & 10,7 & 7,6 & 13,8 & 8 & 7,1 & 6,7 \\
Fixação 5 & 6,3 & 8,5 & 3,1 & 7,6 & 4,5 & 5,8 & 8,9 \\
Fixação 6 & 3,6 & 5,4 & 1,3 & 4 & 2,7 & 1,8 & 2,2 \\
Fixação 7 & 1,8 & 2,7 & 0,4 & 0,4 & 0,9 & 0,9 & 2,7 \\
Fixação 8 & 0,4 & 1,3 & 0,4 & 1,3 & 0,9 & 0,9 & 1,8 \\
Fixação 9 & 1,3 & 1,3 & 0,4 & 0,4 & 0 & 0 & 0,4 \\
Fixação 10 & 0,4 & 1,8 & 0 & 0 & 0 & 0 & 1,3 \\
\hline
\end{tabular}


Anexos 10 - Tabelas para visualização da porcentagem de fixações nas AOI "Boca" por emoção.

Anexo 10.1. Tarefa 1

\begin{tabular}{rrrrrrrr} 
& Alegria & Medo & Neutro & Nojo & Raiva & Surpresa & Tristeza \\
\hline Fixação 1 & 11,2 & 14,3 & 4 & 17 & 13,4 & 15,6 & 4,5 \\
Fixação 2 & 30,8 & 29,9 & 17 & 36,2 & 22,8 & 20,1 & 17,9 \\
Fixação 3 & 32,1 & 26,8 & 16,5 & 32,1 & 26,8 & 25,9 & 19,2 \\
Fixação 4 & 17,4 & 14,7 & 11,6 & 14,3 & 13,4 & 15,2 & 12,9 \\
Fixação 5 & 8,5 & 13,4 & 6,7 & 10,3 & 11,6 & 6,7 & 9,8 \\
Fixação 6 & 6,3 & 11,2 & 5,8 & 7,6 & 6,3 & 4 & 4 \\
Fixação 7 & 1,3 & 8 & 4,5 & 4,5 & 5,8 & 3,1 & 4,9 \\
Fixação 8 & 1,8 & 6,3 & 1,3 & 1,8 & 4 & 1,3 & 2,7 \\
Fixação 9 & 2,7 & 5,4 & 0,9 & 3,6 & 2,2 & 1,3 & 4,5 \\
Fixação & & & & & & & \\
10 & 3,6 & 6,3 & 1,8 & 0,9 & 1,8 & 2,7 & 2,7 \\
\hline
\end{tabular}

Anexo 10.2. Tarefa 2

\begin{tabular}{rrrrrrrr} 
& Alegria & Medo & Neutro & Nojo & Raiva & Surpresa & Tristeza \\
\hline Fixação 1 & 9,4 & 4,9 & 1,3 & 4,5 & 2,7 & 8 & 1,8 \\
Fixação 2 & 37,1 & 25,4 & 13,4 & 29 & 15,2 & 22,8 & 17 \\
Fixação 3 & 33 & 20,5 & 12,5 & 24,6 & 20,1 & 13,4 & 13,8 \\
Fixação 4 & 10,7 & 10,7 & 2,7 & 10,3 & 8,5 & 6,3 & 10,3 \\
Fixação 5 & 4,5 & 4 & 1,3 & 4,9 & 4,9 & 3,6 & 4 \\
Fixação 6 & 4,9 & 5,4 & 1,3 & 0,9 & 1,3 & 0,4 & 2,7 \\
Fixação 7 & 3,1 & 4,9 & 0,9 & 1,3 & 1,3 & 2,2 & 0,9 \\
Fixação 8 & 2,7 & 2,2 & 0,9 & 0,4 & 0,4 & 0 & 1,8 \\
Fixação 9 & 1,8 & 1,3 & 0 & 0 & 0,4 & 0 & 0,4 \\
Fixação & & & & & & & \\
10 & 0 & 0 & 0 & 0 & 0 & 0,4 & 0,9 \\
\hline
\end{tabular}


Anexos 11. Tabelas para visualização da porcentagem de fixações nas AOI "Entre sobrancelhas" por emoção

Anexo 11.1. Tarefa 1

\begin{tabular}{rrrrrrrr} 
& Alegria & Medo & Neutro & Nojo & Raiva & Surpresa & Tristeza \\
\hline Fixação 1 & 8,5 & 4,9 & 6,7 & 5,8 & 15,2 & 5,8 & 11,6 \\
Fixação 2 & 4 & 2,7 & 1,3 & 8,9 & 7,1 & 1,8 & 5,8 \\
Fixação 3 & 4,9 & 1,8 & 1,8 & 1,8 & 6,3 & 2,2 & 2,7 \\
Fixação 4 & 2,2 & 1,3 & 0,9 & 4 & 4 & 1,3 & 0,9 \\
Fixação 5 & 0,9 & 0 & 0,4 & 1,3 & 2,2 & 0,9 & 0,9 \\
Fixação 6 & 0 & 0 & 1,3 & 0 & 0,9 & 0 & 1,3 \\
Fixação 7 & 0,9 & 0,4 & 0 & 2,2 & 0,4 & 0,4 & 1,3 \\
Fixação 8 & 0 & 0,4 & 0 & 1,3 & 0,4 & 0,4 & 0,4 \\
Fixação 9 & 0 & 0,4 & 0,4 & 0,9 & 0,4 & 0 & 0 \\
Fixação & & & & & & & \\
10 & 0 & 0,4 & 0 & 0 & 0 & 0 & 0,4 \\
\hline
\end{tabular}

Anexo 11.2. Tarefa 2

\begin{tabular}{rrrrrrrr} 
& Alegria & Medo & Neutro & Nojo & Raiva & Surpresa & Tristeza \\
\hline Fixação 1 & 4,9 & 4,9 & 10,3 & 7,1 & 27,2 & 4,5 & 12,5 \\
Fixação 2 & 0,9 & 0,4 & 1,3 & 2,2 & 9,8 & 0,9 & 2,7 \\
Fixação 3 & 0 & 0,9 & 0,4 & 0,4 & 1,8 & 1,3 & 1,3 \\
Fixação 4 & 1,3 & 0,4 & 0,9 & 0,9 & 2,2 & 0 & 0,4 \\
Fixação 5 & 0 & 0,4 & 0 & 0 & 0,9 & 0,4 & 0,4 \\
Fixação 6 & 0 & 0 & 0 & 0,4 & 0,4 & 0 & 0 \\
Fixação 7 & 0 & 0,4 & 0 & 0,4 & 0 & 0 & 0 \\
Fixação 8 & 0 & 0 & 0 & 0 & 0,4 & 0 & 0 \\
Fixação 9 & 0 & 0 & 0 & 0 & 0 & 0 & 0 \\
Fixação & & & & & & & \\
10 & 0 & 0,4 & 0 & 0 & 0 & 0 & 0 \\
\hline
\end{tabular}


Anexos 12 - Tabelas para visualização da porcentagem de fixações nas AOI "Testa" por emoção

Anexo 12.1. Tarefa 1

\begin{tabular}{rrrrrrrr} 
& Alegria & Medo & Neutro & Nojo & Raiva & Surpresa & Tristeza \\
\hline Fixação 1 & 8,9 & 3,1 & 10,7 & 16,1 & 14,7 & 6,3 & 7,1 \\
Fixação 2 & 0 & 0 & 1,3 & 0,9 & 1,8 & 0 & 0 \\
Fixação 3 & 0 & 0 & 0,4 & 0 & 0,9 & 0,4 & 0 \\
Fixação 4 & 0,4 & 0 & 0 & 0,9 & 0,9 & 0 & 0 \\
Fixação 5 & 0 & 0 & 0 & 0 & 0,4 & 0 & \\
Fixação 6 & 0 & 0 & 0 & 0,4 & 0 & 0 & 0,4 \\
Fixação 7 & 0 & 0 & 0 & 0 & 0 & 0 & 0,4 \\
Fixação 8 & 0 & 0 & 0 & 0 & 0 & 0 & 0 \\
Fixação 9 & 0 & 0 & 0 & 0,4 & 0 & 0 & 0 \\
Fixação & & & & & & & \\
10 & 0 & 0,4 & 0,4 & 0,4 & 0 & 0 & 0 \\
\hline
\end{tabular}

Anexo 12.2. Tarefa 2

\begin{tabular}{rrrrrrrr} 
& Alegria & Medo & Neutro & Nojo & Raiva & Surpresa & Tristeza \\
\hline Fixação 1 & 3,1 & 0,9 & 6,7 & 4,9 & 15,6 & 0,4 & 14,7 \\
Fixação 2 & 0 & 0 & 1,3 & 0,9 & 1,3 & 0 & 0,9 \\
Fixação 3 & 0 & 0 & 0,4 & 1,3 & 0,4 & 0,4 & 0,9 \\
Fixação 4 & 0,4 & 0 & 0,9 & 0,9 & 0,4 & 0,4 & 0 \\
Fixação 5 & 0,9 & 0 & 0 & 0 & 0 & 0 & 0 \\
Fixação 6 & 0,4 & 0 & 0 & 0,4 & 0,4 & 0 & 0 \\
Fixação 7 & 0 & 0,4 & 0 & 0 & 0 & 0 & 0 \\
Fixação 8 & 0 & 0 & 0 & 0 & 0 & 0 & 0 \\
Fixação 9 & 0 & 0 & 0 & 0 & 0 & 0,4 & 0 \\
Fixação & & & & & & & \\
10 & 0 & 0 & 0 & 0 & 0 & 0,4 & 0 \\
\hline
\end{tabular}


Anexos 13. Tabelas de visualização da porcentagem de fixações nas AOI "Olhos" por emoção

Anexo 13. 1. Tarefa 1

\begin{tabular}{|c|c|c|c|c|c|c|c|c|c|c|c|c|c|c|}
\hline Tarefa 1 & Alegria & & Medo & & Neutro & & Nojo & & Raiva & & Supresa & & Tristeza & \\
\hline & $O D$ & $\mathrm{OE}$ & OD & $\mathrm{OE}$ & OD & $\mathrm{OE}$ & $O D$ & $\mathrm{OE}$ & OD & $\mathrm{OE}$ & OD & $\mathrm{OE}$ & OD & $\mathrm{OE}$ \\
\hline Fixação 1 & 18,8 & 6,3 & 15,6 & 3,6 & 19,2 & 4,5 & 13,8 & 3,6 & 13,8 & 3,6 & 24,1 & 3,6 & 22,3 & 6,7 \\
\hline Fixação 2 & 10,3 & 4,5 & 11,6 & 6,3 & 17 & 9,8 & 8,5 & 5,8 & 8,5 & 8,5 & 14,7 & 12,5 & 15,2 & 10,3 \\
\hline Fixação 3 & 10,3 & 7,6 & 8,5 & 13,8 & 13,4 & 20,1 & 11,6 & 10,7 & 15,2 & 10,3 & 11,2 & 13,4 & 12,5 & 14,3 \\
\hline Fixação 4 & 8,9 & 10,7 & 12,5 & 13,8 & 15,6 & 11,6 & 12,9 & 9,4 & 10,7 & 12,5 & 8,5 & 10,7 & 13,8 & 13,8 \\
\hline Fixação 5 & 8,9 & 7,6 & 8,5 & 12,9 & 11,2 & 12,1 & 5,8 & 8,9 & 5,8 & 9,4 & 8,5 & 8,5 & 11,6 & 11,6 \\
\hline Fixação 6 & 4,9 & 3,6 & 9,4 & 6,3 & 8 & 5,4 & 3,6 & 4,5 & 8,9 & 5,8 & 7,1 & 5,4 & 8 & 8 \\
\hline Fixação 7 & 4 & 3,1 & 5,4 & 4,9 & 4 & 8,5 & 3,6 & 3,1 & 4 & 6,3 & 2,7 & 6,3 & 5,4 & 4 \\
\hline Fixação 8 & 0,9 & 2,7 & 4,9 & 4,5 & 6,3 & 2,7 & 1,3 & 4 & 2,7 & 2,2 & 3,6 & 2,2 & 3,1 & 5,4 \\
\hline Fixação 9 & 1,3 & 0,9 & 3,1 & 4,5 & 4,5 & 3,6 & 0,4 & 1,8 & 2,2 & 1,8 & 2,7 & 4,9 & 1,3 & 4,9 \\
\hline Fixação 10 & 0,9 & 0,4 & 1,8 & 3,6 & 2,7 & 2,2 & 1,3 & 2,2 & 2,2 & 1,3 & 1,8 & 0,9 & 2,2 & 2,7 \\
\hline
\end{tabular}

Anexo 13.2. Tarefa 2

\begin{tabular}{|c|c|c|c|c|c|c|c|c|c|c|c|c|c|c|}
\hline Tarefa 2 & Alegria & & Medo & & Neutro & & Nojo & & Raiva & & Supresa & & Tristeza & \\
\hline & $O D$ & $\mathrm{OE}$ & OD & $\mathrm{OE}$ & OD & $\mathrm{OE}$ & OD & $\mathrm{OE}$ & OD & $\mathrm{OE}$ & OD & $\mathrm{OE}$ & $O D$ & $\mathrm{OE}$ \\
\hline Fixação 1 & 24,6 & 1,3 & 17,4 & 2,2 & 18,3 & 4,5 & 13,4 & 1,3 & 14,3 & 2,7 & 23,2 & 0,9 & 22,3 & 3,6 \\
\hline Fixação 2 & 13,8 & 5,8 & 13,4 & 8,5 & 17 & 10,3 & 12,5 & 4 & 17,9 & 6,3 & 18,8 & 9,8 & 23,7 & 9,4 \\
\hline Fixação 3 & 10,7 & 4 & 12,5 & 10,3 & 13,8 & 10,7 & 8 & 7,1 & 11,6 & 11,2 & 15,2 & 5,8 & 15,6 & 13,4 \\
\hline Fixação 4 & 11,6 & 5,8 & 12,1 & 8 & 7,1 & 5,4 & 6,7 & 5,4 & 11,2 & 7,1 & 10,3 & 7,1 & 11,6 & 10,7 \\
\hline Fixação 5 & 5,4 & 6,7 & 6,3 & 5,8 & 2,7 & 3,1 & 5,8 & 2,2 & 4,9 & 4,5 & 1,3 & 2,2 & 6,7 & 4,5 \\
\hline Fixação 6 & 2,2 & 2,7 & 2,2 & 4,5 & 1,3 & 1,8 & 2,7 & 2,2 & 4,5 & 0,9 & 1,8 & 1,8 & 5,4 & 5,4 \\
\hline Fixação 7 & 1,8 & 0,9 & 2,2 & 1,3 & 0,9 & 0,4 & 2,7 & 0,9 & 2,2 & 0,4 & 0 & 0,4 & 4,9 & 2,2 \\
\hline Fixação 8 & 2,7 & 0,4 & 4,5 & 0,9 & 0 & 0,9 & 0,4 & 0,4 & 0,4 & 0,9 & 0,4 & 0,9 & 3,6 & 1,3 \\
\hline Fixação 9 & 0,4 & 0,4 & 0,9 & 1,3 & 1,3 & 0 & 0,4 & 0,9 & 0 & 0,4 & 0,4 & 0,9 & 2,2 & 2,2 \\
\hline Fixação 10 & 1,8 & 0,9 & 0,9 & 0,9 & 0 & 0,4 & 0,4 & 0,9 & 0 & 0 & 0 & 0,4 & 0,4 & 1,8 \\
\hline
\end{tabular}


Anexos 14 - Tabelas de visualização da porcentagem de fixações nas AOls "Sobrancelhas".

Anexo 14. 1 Tarefa 1

\begin{tabular}{|c|c|c|c|c|c|c|c|c|c|c|c|c|c|c|}
\hline Tarefa 1 & Alegria & & Medo & & Neutro & & Nojo & & Raiva & & Supresa & & Tristeza & \\
\hline & SD & SE & SD & SE & SD & SE & SD & SE & SD & SE & SD & SE & SD & SE \\
\hline Fixação 1 & 10,7 & 3,1 & 6,3 & 0,9 & 8 & 0,4 & 6,7 & 13,4 & 12,5 & 1,3 & 7,1 & 0,9 & 8,9 & 3,6 \\
\hline Fixação 2 & 0,4 & 0,4 & 0,4 & 0,4 & 0,9 & 1,3 & 0 & 7,1 & 1,8 & 0,4 & 0 & 0,9 & 0 & 1,3 \\
\hline Fixação 3 & 0 & 0,4 & 0,4 & 0,4 & 0,4 & 0,4 & 0 & 4,9 & 0,4 & 0,9 & 0 & 0,4 & 1,3 & 0,4 \\
\hline Fixação 4 & 0,4 & 0,4 & 0 & 0 & 0,4 & 0 & 0 & 3,1 & 0,9 & 0,4 & 0,4 & 0,4 & 1,3 & 0,9 \\
\hline Fixação 5 & 0 & 0,4 & 0,4 & 0,4 & 0 & 0 & 0 & 1,8 & 0,9 & 0 & 0 & 0 & 0,9 & 0,4 \\
\hline Fixação 6 & 0 & 0 & 0,4 & 0 & 0,4 & 0 & 0 & 0,9 & 0,9 & 0 & 0 & 0 & 0 & 0,4 \\
\hline Fixação 7 & 0 & 0 & 0 & 0 & 0 & 0,4 & 0 & 0,9 & 0,4 & 0,4 & 0 & 0 & 0,4 & 0 \\
\hline Fixação 8 & 0,4 & 0 & 0 & 0 & 0 & 0,4 & 0 & 0 & 0,4 & 0 & 0 & 0 & 0,4 & 0 \\
\hline Fixação 9 & 0 & 0 & 0,4 & 0 & 0 & 0 & 0 & 0 & 0,4 & 0 & 0 & 0 & 0,4 & 0 \\
\hline Fixação 10 & 0 & 0 & 0 & 0 & 0 & 0 & 0 & 1,3 & 0 & 0 & 0,4 & 0 & 0 & 0 \\
\hline
\end{tabular}

Anexo 14.2. Tarefa 2

\begin{tabular}{|c|c|c|c|c|c|c|c|c|c|c|c|c|c|c|}
\hline Tarefa 2 & Alegria & & Medo & & Neutro & & Nojo & & Raiva & & Supresa & & Tristeza & \\
\hline & SD & SE & SD & SE & SD & SE & SD & SE & SD & SE & SD & SE & SD & SE \\
\hline Fixação 1 & 8,9 & 0 & 3,1 & 17,9 & 4,5 & 0,4 & 8,5 & 1,8 & 10,7 & 0,9 & 1,3 & 0 & 7,6 & 1,3 \\
\hline Fixação 2 & 1,3 & 0,4 & 0 & 8,9 & 0,4 & & 2,7 & 0,4 & 2,7 & 0,4 & 0,9 & 1,3 & 2,2 & 1,3 \\
\hline Fixação 3 & 0,4 & 0,9 & 0,4 & 4 & 1,3 & 0,9 & 0,9 & 0,9 & 1,8 & 0,9 & 0,9 & 0,4 & 0,4 & c \\
\hline Fixação 4 & 0 & 0,4 & 0 & 2,7 & 0,4 & 0 & 0,4 & 0,4 & 1,3 & 0,4 & 0 & 0 & 0,9 & c \\
\hline Fixação 5 & 0,4 & 0 & 0 & 1,8 & 0,4 & 0 & 0,4 & 0 & 1,3 & 0 & 0 & 0 & 0 & c \\
\hline Fixação 6 & 0,4 & 0 & 0 & 0,9 & 0 & 0 & 0 & 0 & 1,3 & 0,4 & 0 & 0 & 0,4 & c \\
\hline Fixação 7 & 0 & 0 & 0 & 0,9 & 0 & 0 & 0 & 0 & 0 & 0 & 0 & 0 & 0 & c \\
\hline Fixação 8 & 0 & 0 & 0 & 0,4 & 0 & 0 & 0,4 & 0 & 0 & 0 & 0 & 0 & 0 & c \\
\hline Fixação 9 & 0,4 & 0 & 0 & 0 & 0 & 0 & 0,4 & 0 & 0,4 & 0 & 0 & 0 & 0 & c \\
\hline Fixação 10 & 0 & 0 & 0 & 0 & 0 & 0 & 0 & 0 & 0 & 0 & 0 & 0 & 0 & c \\
\hline
\end{tabular}


Anexo 15 - Porcentagem de hits nas AOls conforme sequência de fixações para as tarefas 1 (fig. A) e 2 (fig. B) - MEDO.

\section{(A) Tarefa 1}

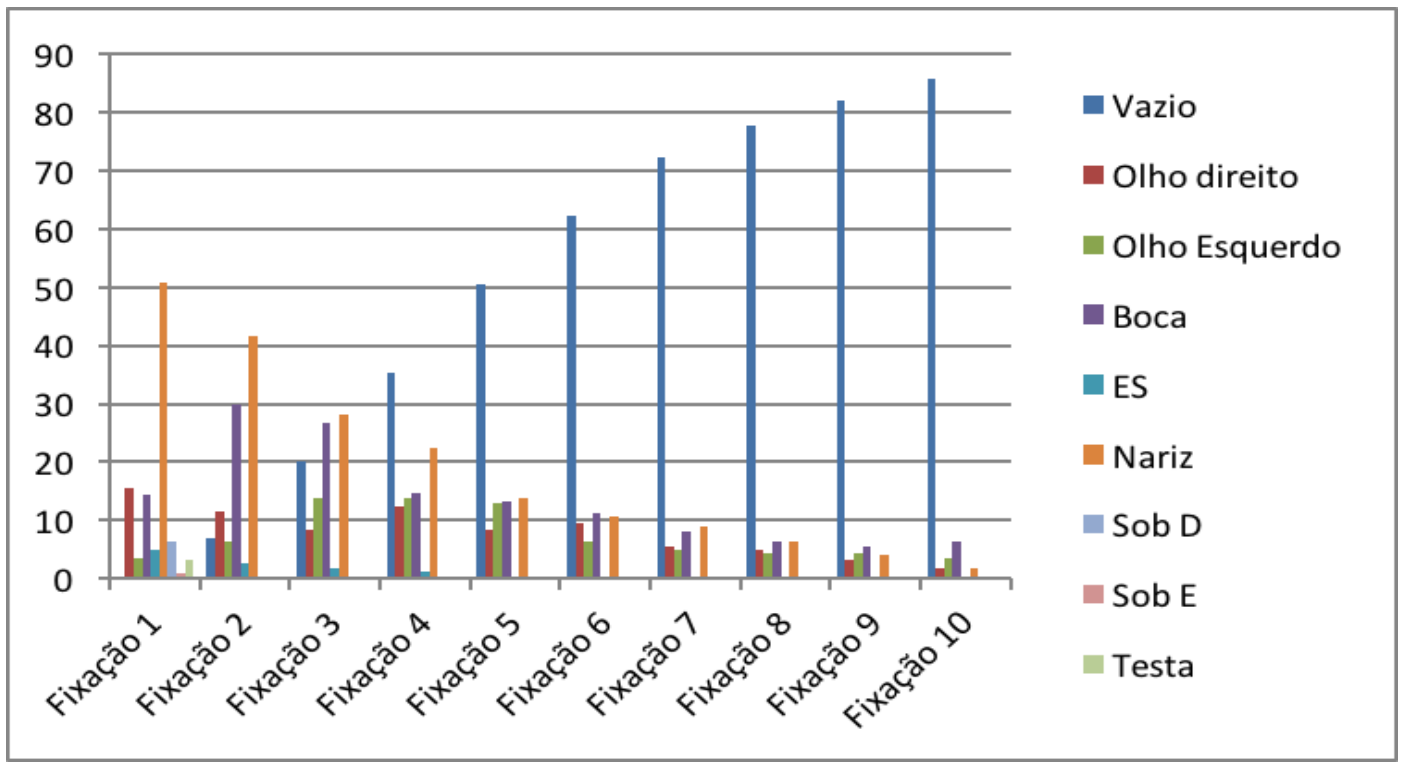

(B) Tarefa 2

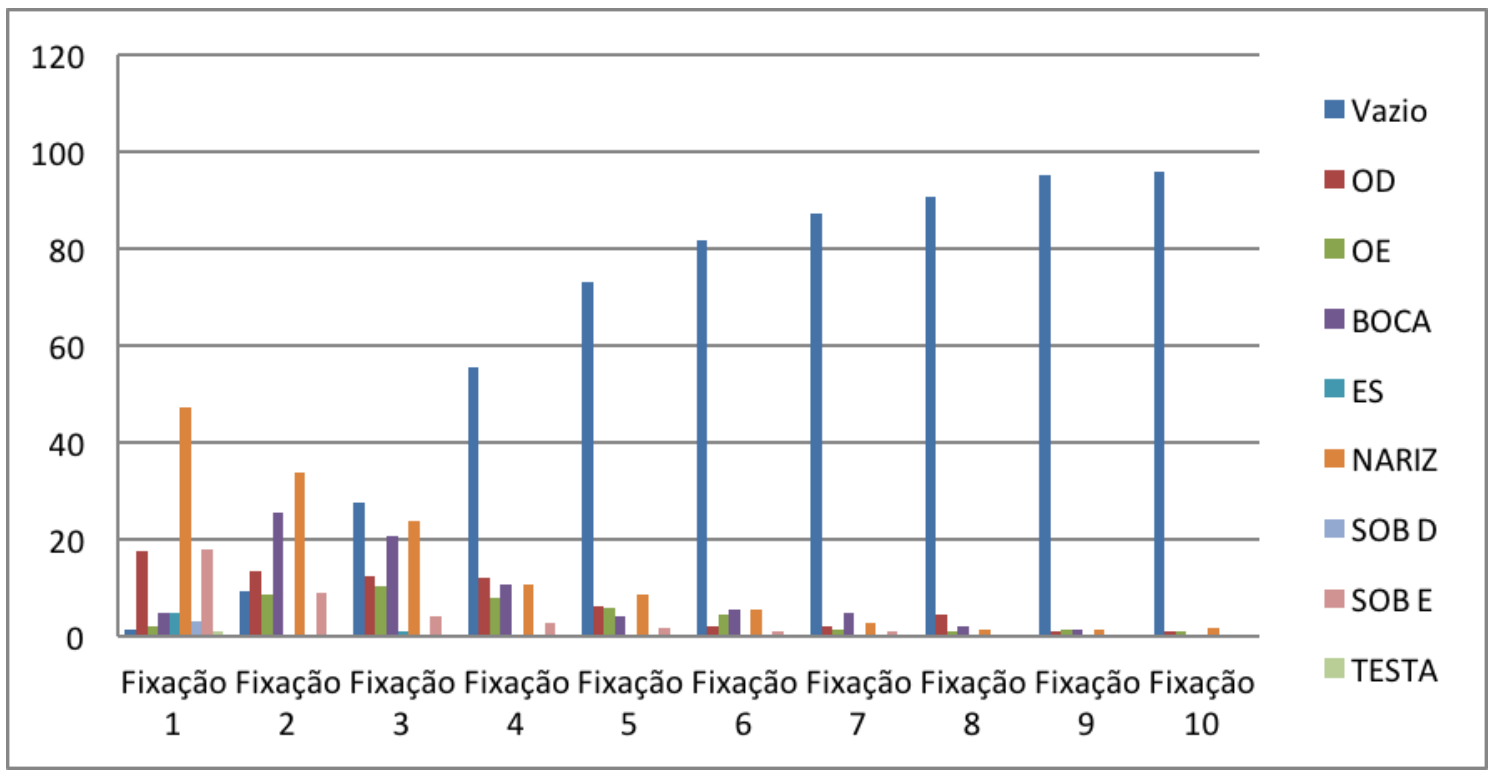


Anexo 16 - Porcentagem de hits nas AOls conforme sequência de fixações para as tarefas 1 (fig. A) e 2 (fig. B) - NEUTRO.

(A) Tarefa 1

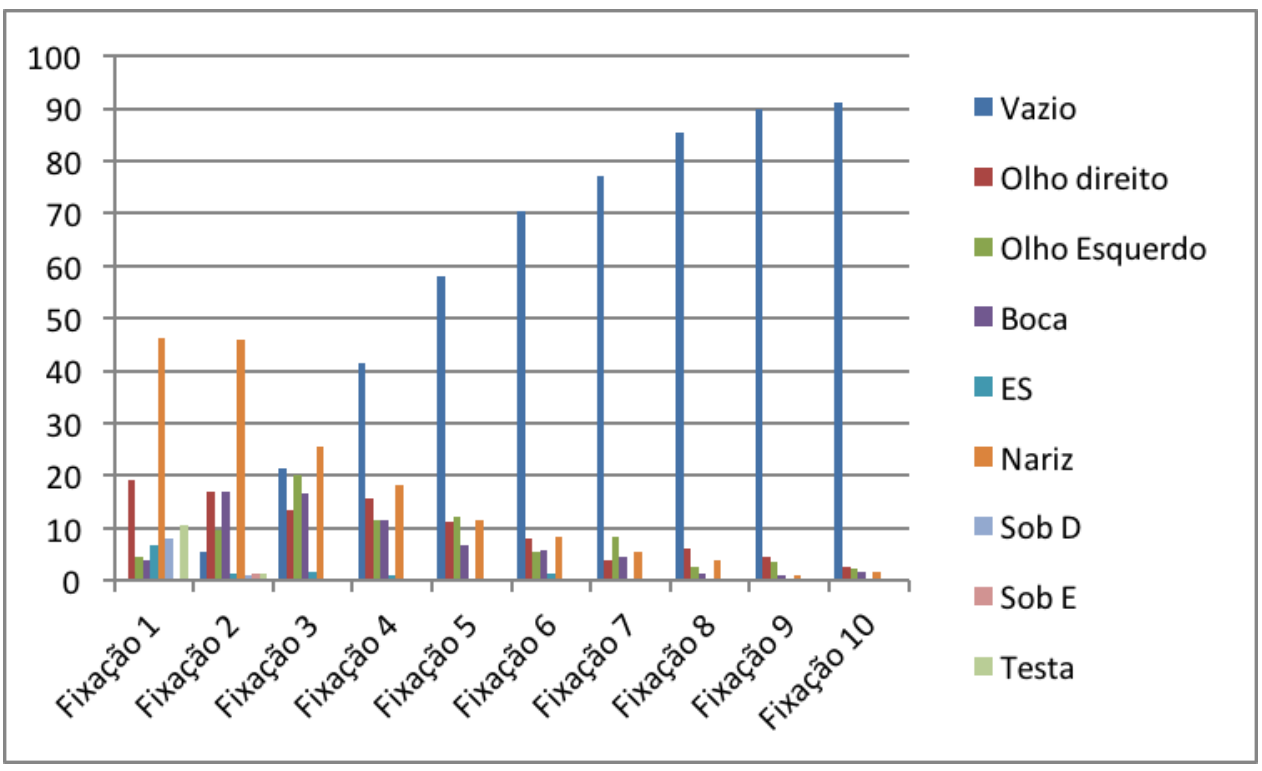

(B) Tarefa 2

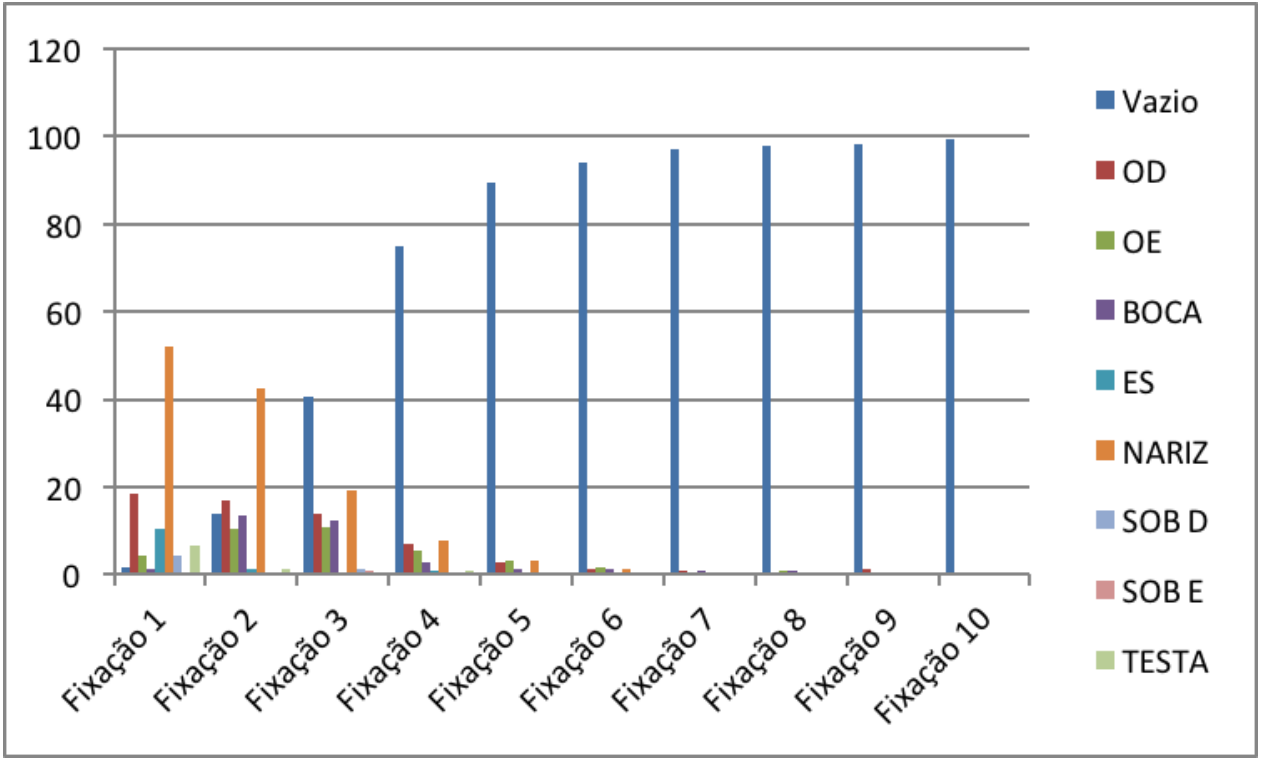


Anexo 17 - Porcentagem de hits nas AOls conforme sequência de fixações para as tarefas 1 (fig. A) e 2 (fig. B) - NOJO.

(A) Tarefa 1

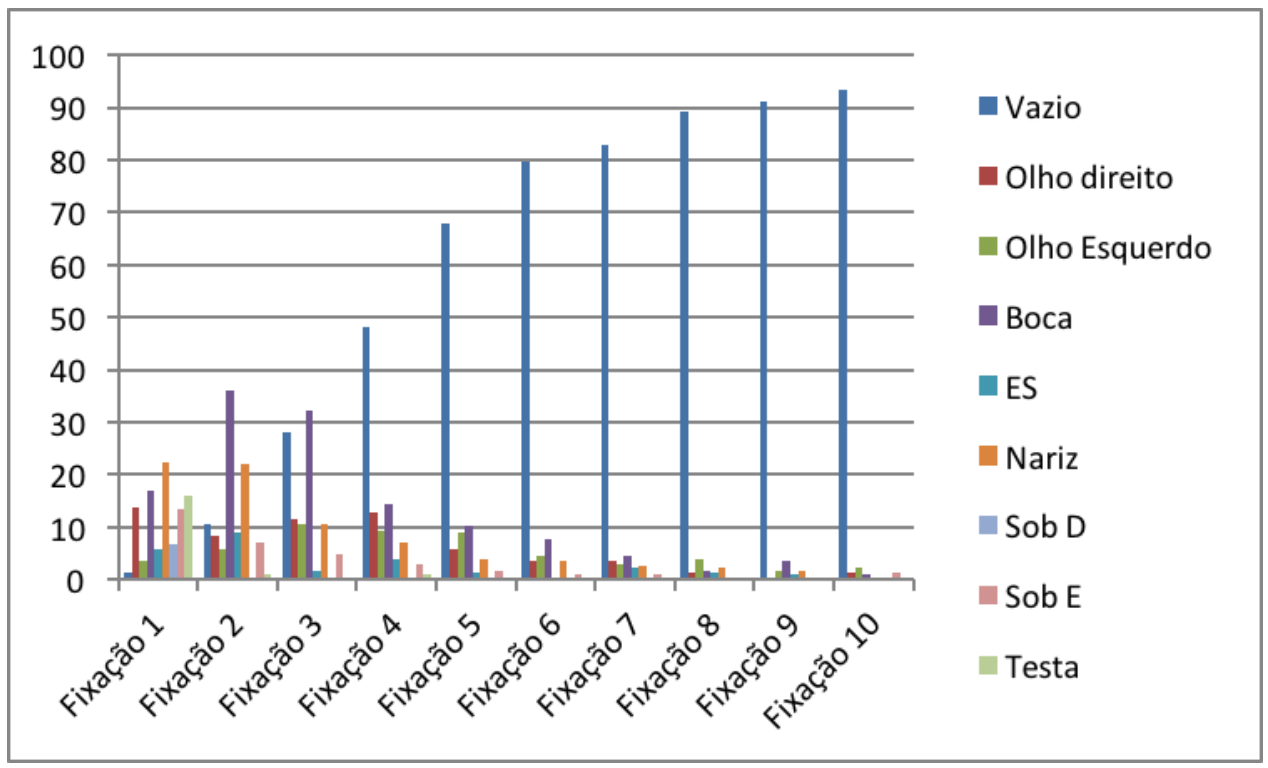

(B) Tarefa 2

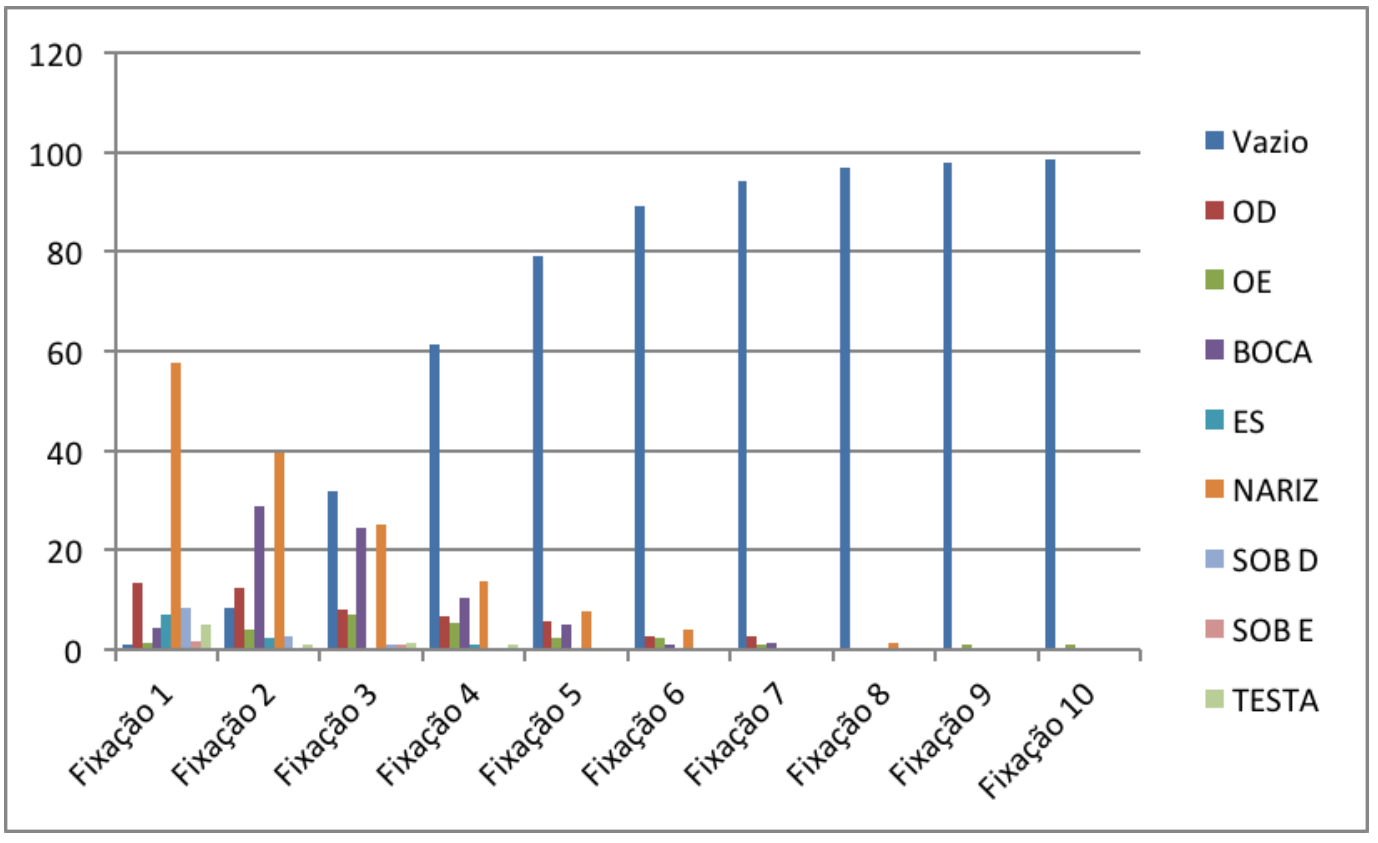


Anexo 18 - Porcentagem de hits nas AOls conforme sequência de fixações para as tarefas 1 (fig. A) e 2 (fig. B) - RAIVA
(A) Tarefa 1

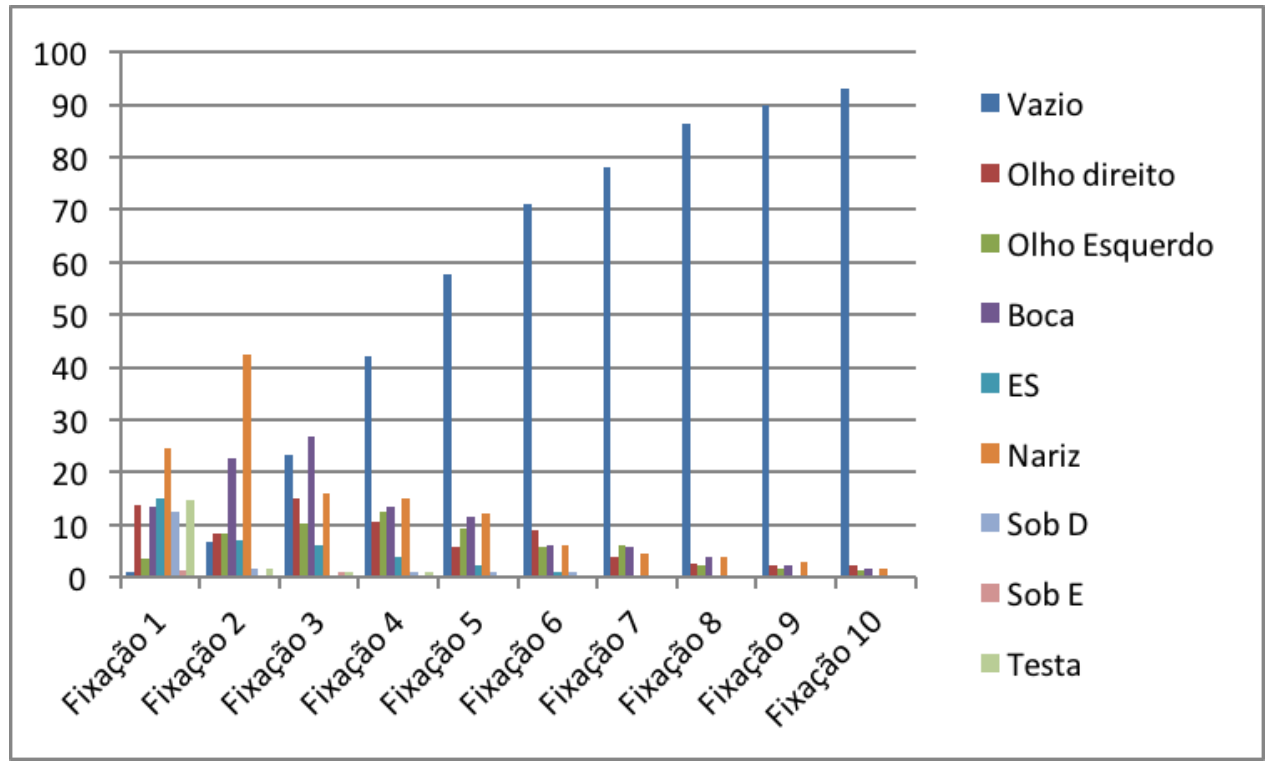

(B) Tarefa 2

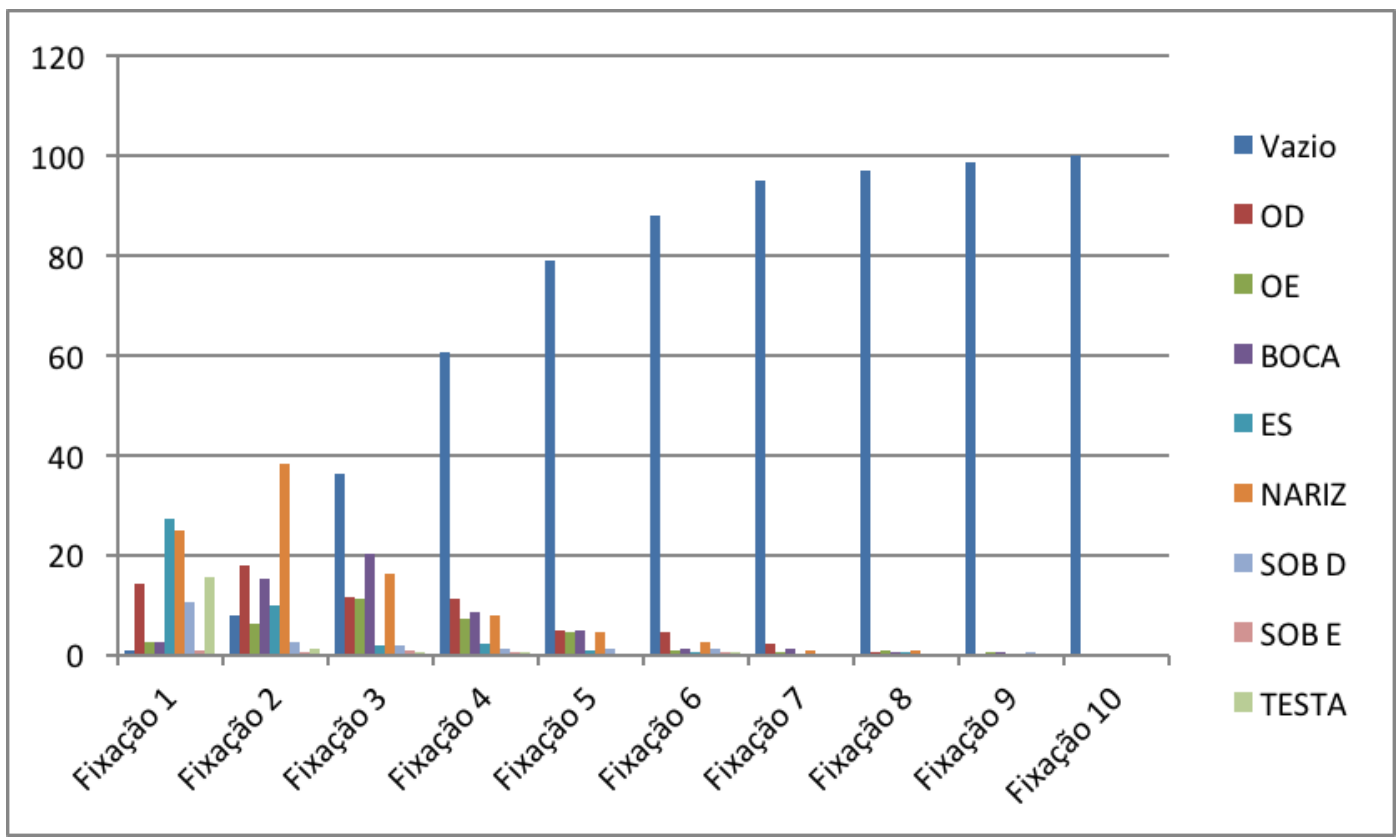


Anexo 19 - Porcentagem de hits nas AOls conforme sequência de fixações para as tarefas 1 (fig. A) e 2 (fig. B) - SURPRESA

(A) Tarefa 1

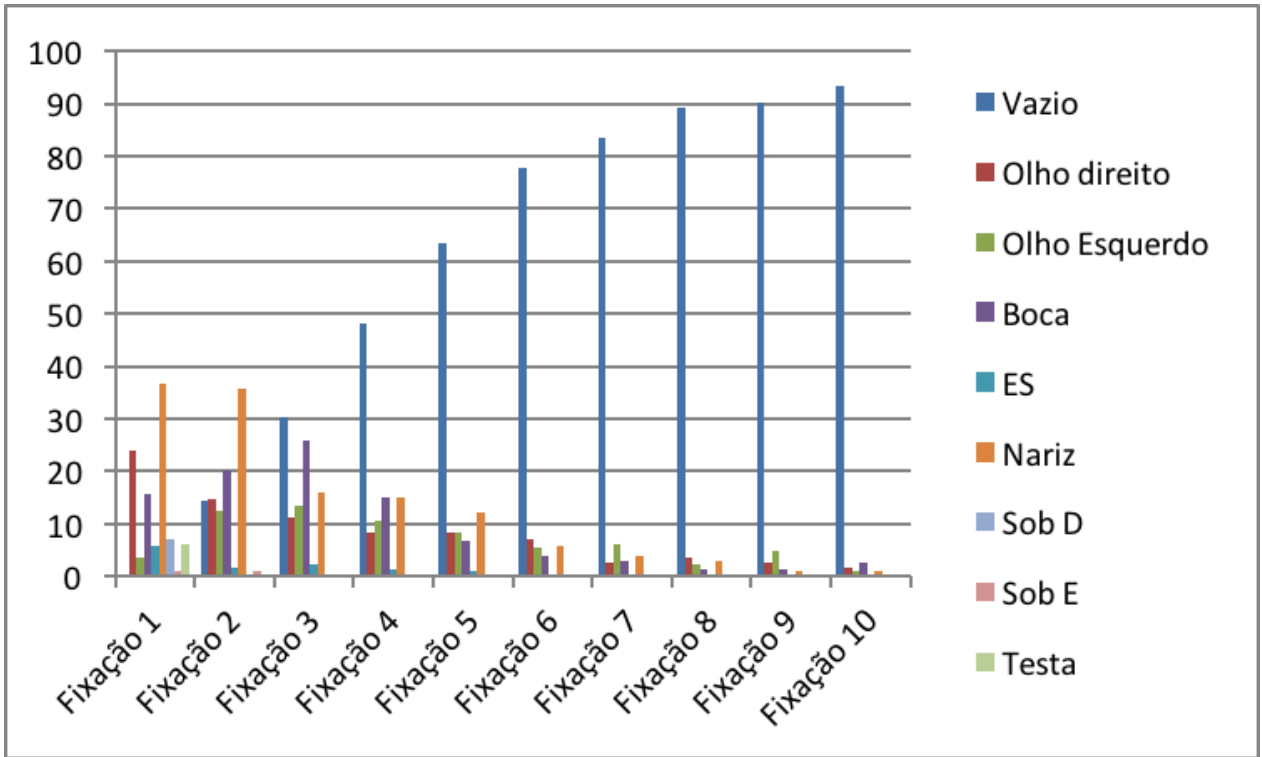

(B) Tarefa 2

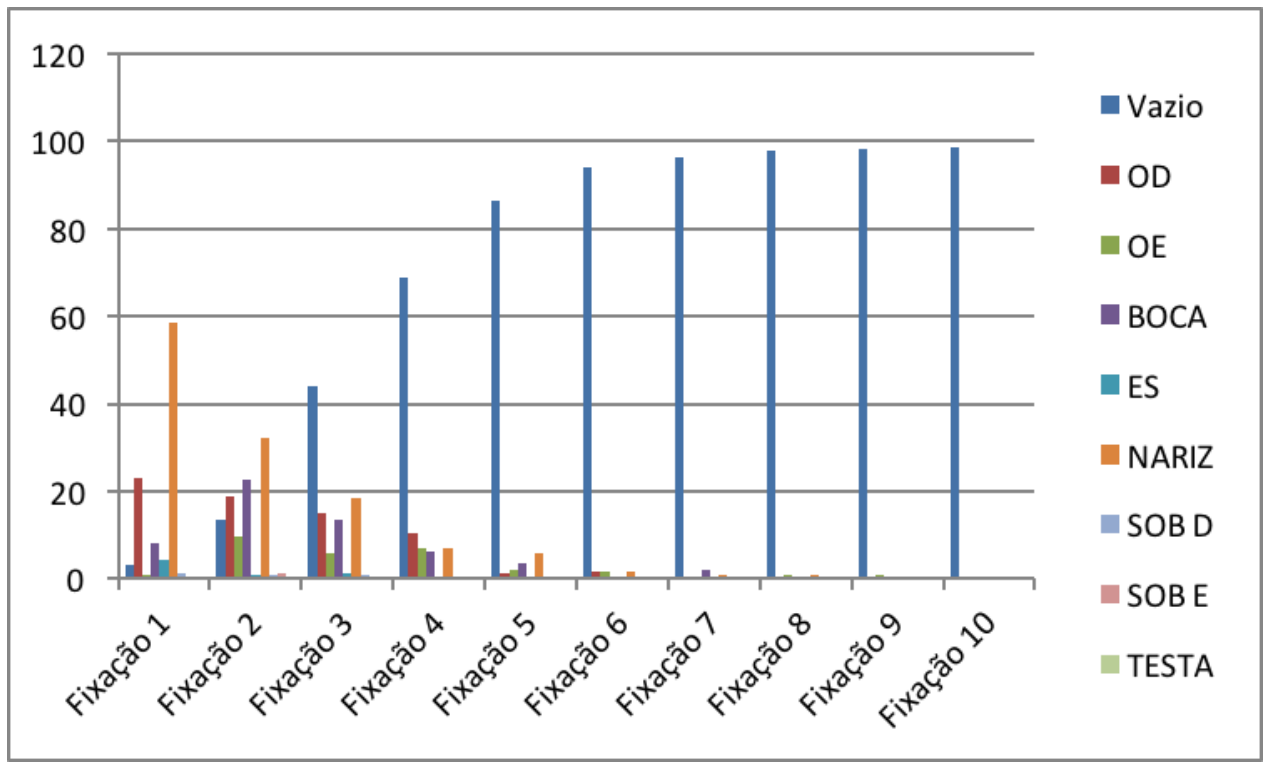


Anexo 20 - Porcentagem de hits nas AOls conforme sequência de fixações para as tarefas 1 (fig. A) e 2 (fig. B) - TRISTEZA

(A) Tarefa 1

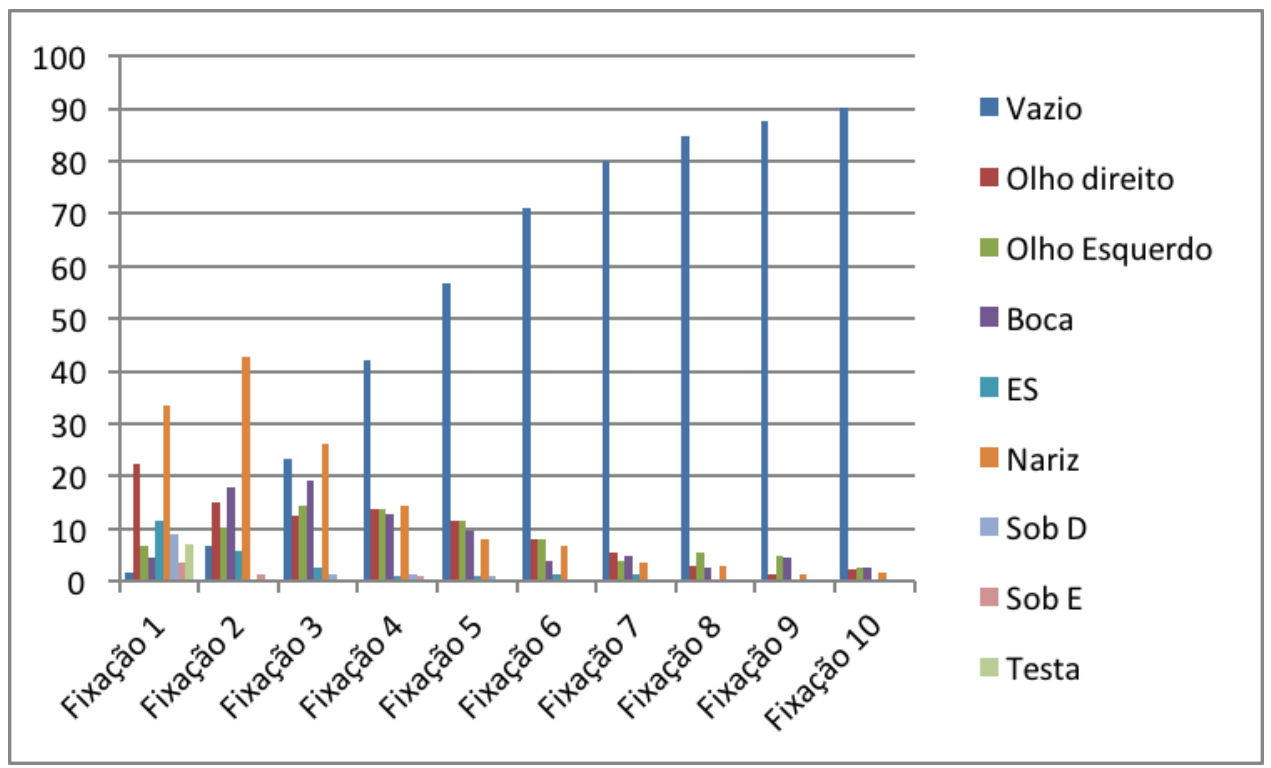

(B) Tarefa 2

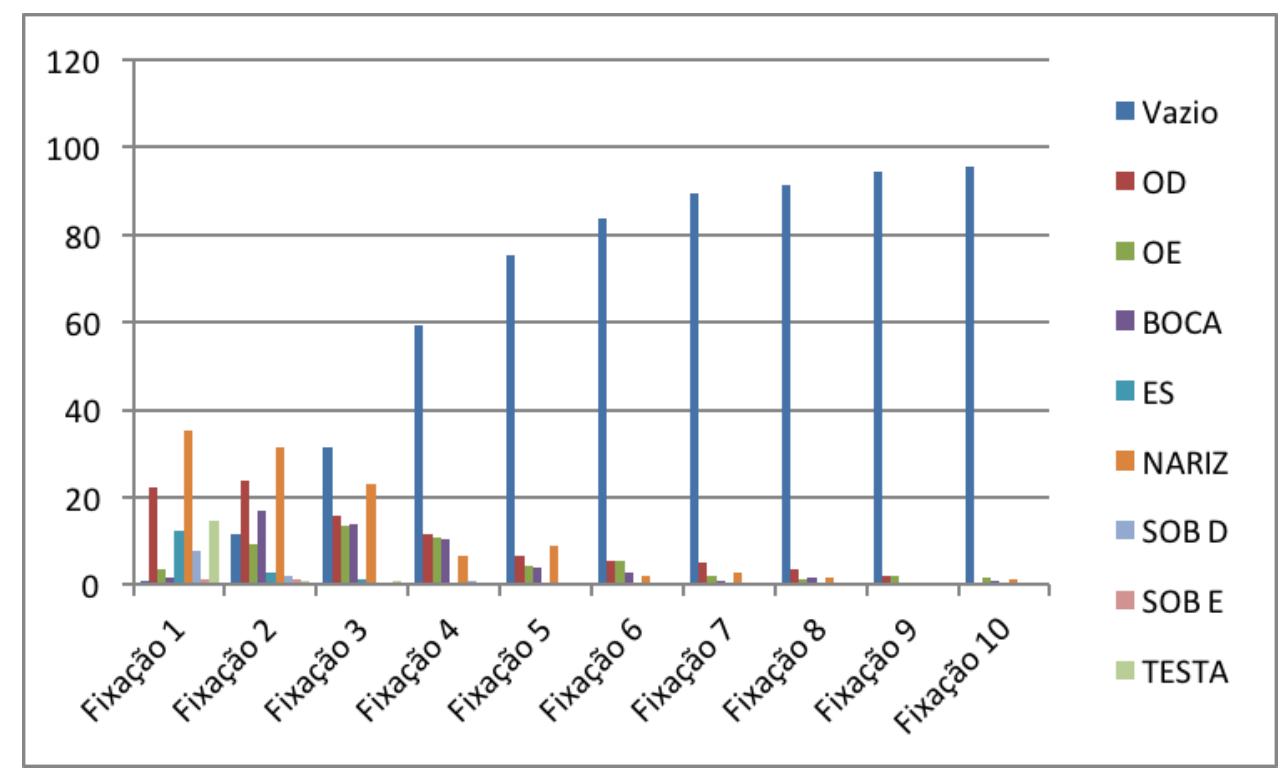

